\title{
BRUNO DUZZI
}

Busca de novos substratos e/ou inibidores das enzimas timet oligopeptidase (E.C.

3.4.24.15) e neurolisina (E.C. 3.4.24.16) nas frações de baixa massa molecular do veneno do escorpião Tityus serrulatus

Dissertação apresentada ao Programa de Pós-Graduação Interunidades em Biotecnologia USP/Instituto Butantan/IPT, para obtenção do Título de Mestre em Biotecnologia.

São Paulo

2014 


\section{BRUNO DUZZI}

Busca de novos substratos e/ou inibidores das enzimas timet oligopeptidase (E.C.

3.4.24.15) e neurolisina (E.C. 3.4.24.16) nas frações de baixa massa molecular do veneno do escorpião Tityus serrulatus

Dissertação apresentada ao Programa de Pós-Graduação Interunidades em Biotecnologia USP/Instituto Butantan/IPT, para obtenção do Título de Mestre em Biotecnologia.

Área de concentração: Biotecnologia

Orientadora: Dra. Vanessa Rioli

Coorientadora: Dra. Fernanda C. V. Portaro

Versão corrigida. A versão original eletrônica encontra-se disponível tanto na Biblioteca do ICB quanto na Biblioteca Digital de Teses e Dissertações da USP (BDTD). 
DADOS DE CATALOGAÇÃO NA PUBLICAÇÃO (CIP)

Serviço de Biblioteca e Informação Biomédica do

Instituto de Ciências Biomédicas da Universidade de São Paulo

(C) reprodução total

Duzzi, Bruno.

Busca de novos substratos e/ou inibidores das enzimas timet oligopeptidase (E.C.3.4.24.15) e neurolisina (E.C.3.4.24.16) nas frações de baixa massa molecular do veneno do escorpião Tityus serrulatus / Bruno Duzzi. -- São Paulo, 2014.

Orientador: Profa. Dra. Vanessa Rioli.

Dissertação (Mestrado) - Universidade de São Paulo. Instituto de Ciências Biomédicas. Programa de Pós-Graduação Interunidades em Biotecnologia USP/IPT/Instituto Butantan. Área de concentração: Biotecnologia. Linha de pesquisa: Inibidores de metalopeptidases presentes em toxinas animais.

Versão do título para o inglês: Search for new substrates and/or inhibitors of thimet oligopeptidase (EC3.4.24.15) and neurolysin (EC3.4.24.16) enzymes in low molecular weight fractions of Tityus serrulatus scorpion venom.

$\begin{array}{lll}\text { 1. Tityus serrulatus } & 2 \text {. Escorpião amarelo } & 3 \text {. Componentes do veneno }\end{array}$ 4. Peptídeos 5. Oligopeptidases 6. EP 24.15 e EP 24.16 I. Rioli, Profa. Dra. Vanessa II. Universidade de São Paulo. Instituto de Ciências Biomédicas. Programa de Pós-Graduação Interunidades em Biotecnologia USP/IPT/Instituto Butantan III. Título. 
Candidato(a):

Título da Dissertação:

Orientador(a):
Bruno Duzzi.

Busca de novos substratos e/ou inibidores das enzimas timet oligopeptidase (E.C.3.4.24.15) e neurolisina (E.C.3.4.24.16) nas frações de baixa massa molecular do veneno do escorpião Tityus serrulatus.

Profa. Dra. Vanessa Rioli.

\begin{abstract}
A Comissão Julgadora dos trabalhos de Defesa da Dissertação de Mestrado, em sessão pública realizada a ........... considerou
\end{abstract}
( ) Aprovado(a)
( ) Reprovado(a)

Examinador(a): Assinatura:

Nome:

Instituição:

Examinador(a): Assinatura:

Nome:

Instituição:

Presidente: Assinatura:

Nome:

Instituição: 


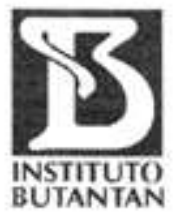

\section{COMISSÃO DE ÉTICA NO USO DE ANIMAIS \\ INSTITUTO BUTANTAN \\ Av. Dr. Vital Brazil, 1500, CEP 05503-900, Sảo Paulo, SP, Brazil \\ Telefone: (55) (011) 2627-9585 - Fax: (55) (011) 2627-9505 \\ ceuaib@butantan.gov.br}

\section{CERTIFICADO}

Certificamos que o projeto intitulado "Possiveis alteraçōes da sensibilidade dolorosa induzida por novos substratos e/ ou inibidores para EP24.15 e EP24.16 obtidos das fraçōes de baixo peso molecular do veneno do escorpiào Tityus serrulatus", protocolo ${ }^{\circ}{ }^{\circ} 863 / 11$, sob a responsabilidade de Vanessa Rioli e Bruno Duzzi - que envolve a criaçăo e/ou utilização de animais pertencentes ao filo Chordata, subfilo Vertebrata (exceto o homem), para fins de pesquisa científica - está de acordo com os preceitos da Lei n ${ }^{\circ} 11.794$, de 8 de outubro de 2008, do Decreto 6.899, de 15 de julho de 2009 e de normas complementares, bem como está de acordo com os Princípios Éticos na Experimentação Animal adotado pelo Colégio Brasileiro de Experimentaçăo Animal (COBEA), e foi aprovado pela COMISSĀO DE ÉTICA NO USO DE ANIMAIS DO INSTITUTO BUTANTAN (CEUAIB) em reuniăo de $08 / 12 / 2011$.

We certify that the research entitled "Possible changes in pain sensitivity induced by new substrates and/ or inhibitors for EP24.15 and EP24.16 obtained from low molecular weight fractions of the venom of the scorpion Tityus serrulatus", protocol number 863/11, under the responsibility of Vanessa Rioli and Bruno Duzzi - which involves the breeding and/or use of animals belonging to phylum Chordata, subphylum Vertebrata (except human beings), for scientific research - is in agreement with Brazilian laws for use of experimental animals and the Ethical Principles in Animal Research adopted by the Brazilian College of Animal Experimentation, and was approved by the ETHICAL COMMITTEE FOR ANIMAL RESEARCH of BUTANTAN INSTITUTE in the meeting of $12 / 08 / 2011$.

\begin{tabular}{|c|c|}
\hline $\begin{array}{c}\text { Vigência do Projeto: } \\
10 / 2011-08 / 2013\end{array}$ & $\mathbf{N}^{*}$ de animais/espécie \\
\hline Laboratório Especial de \\
Toxinologia Aplicada
\end{tabular}

São Paulo, 12 de Dezembro de 2011.

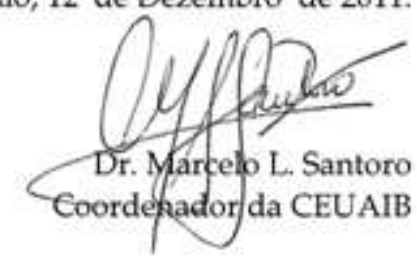




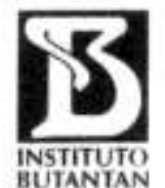

\section{COMISSÃO DE ÉTICA NO USO DE ANIMAIS \\ INSTITUTO BUTANTAN}

Av. Dr. Vital Brazil, 1500, CEP 05503-900, Såo Paulo, SP, Brazil

Telefone: (55) (011) 2627-9585 - Fax: (55) (011) $2627-9505$

ceuaib@butantan.govbr

\section{CERTIFICADO}

Certificamos que o projeto intitulado "Possiveis alteraçôes da sensibilidade dolorosa induzida por novos substratos e/ ou inibidores para EP 24.15 e EP 24.16 obtidos das fraçòes de baixo peso molecular do veneno do escorpiāo Tityus serrulatus", protocolo n $863 / 11$, sob a responsabilidade de Vanessa Rioli e Bruno Duzzi - que envolve a criação e/ou utilizaçăo de animais pertencentes ao filo Chordata, subfilo Vertebrata (exceto o homem), para fins de pesquisa cientifica - está de acordo com os preceitos da Lei $n^{\circ} 11.794$, de 8 de outubro de 2008, do Decreto 6.899 , de 15 de julho de 2009 e de normas complementares, bem como esta de acordo com os Principios Éticos na Experimentaçào Animal adotado pelo Colégio Brasileiro de Experimentaçằo Animal (COBEA), e foi aprovado pela COMISSĀO DE ÉTICA NO USO DE ANIMAIS DO INSTITUTO BUTANTAN (CEUAIB) em reuniâo de 11/9/2013.

\begin{tabular}{|c|c|c|}
\hline $\begin{array}{c}\text { Vigência do Projeto: } \\
10 / 2011-11 / 2013\end{array}$ & N $^{*}$ de animais/espécie & Observação \\
\hline $\begin{array}{c}\text { Lahoratório Fspecial de } \\
\text { Toxinologia Aplicsda }\end{array}$ & $\begin{array}{c}552 \text { ratos Wistar }(\mathrm{M}) ; \\
268 \text { camundongos Swiss }(\mathrm{M})\end{array}$ & Alteraçâo de vigễncia \\
\cline { 2 - 3 }
\end{tabular}

Săo Paulo, 13 de setembro de 2013

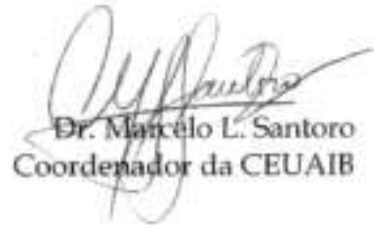


Av. Dr. Vital Brazil, 1500, CEP 05503-900, São Paulo, SP, Brazil

Telefone: (55) (011) 2627-9585 - Fax: (55) (011) 2627-9505

ceuaib@butantan.gov.br

\section{CERTIFICADO}

Certificamos que o projeto intitulado "Possiveis alterações da sensibilidade dolorosa induzida por novos substratos e/ ou inibidores para EP 24.15 e EP 24.16 obtidos das fraçôes de baixo peso molecular do veneno do escorpiẫo Tityus serrulatus", protocolo ${ }^{\circ}{ }^{863 / 11}$, sob a responsabilidade de Vanessa Rioli e Bruno Duzzi - que envolve a criaçăo e/ou utilizaçăo de animais pertencentes ao filo Chordata, subfilo Vertebrata (exceto o homem), para fins de pesquisa científica - está de acordo com os preceitos da Lei $\mathrm{n}^{\circ} 11.794$, de 8 de outubro de 2008, do Decreto 6.899, de 15 de julho de 2009 e de normas complementares, bem como está de acordo com os Princípios Éticos na Experimentaçăo Animal adotado pelo Colégio Brasileiro de Experimentação Animal (COBEA), e foi aprovado pela COMISSĀO DE ÉTICA NO USO DE ANIMAIS DO INSTITUTO BUTANTAN (CEUAIB) em reunião de 11/12/2013.

This is to certify that the proposal Possible changes in pain sensitivity induced by new substrates and/ or inhibitors for EP24.15 and EP24.16 obtained from low molecular weight fractions of the venom of the scorpion Tityus serrulatus, protocol $\mathrm{n}^{\circ} 863 / 11$, under the responsibility of Vanessa Rioli and Bruno Duzzi, - which involves the breeding and/or use of animals belonging to phylum Chordata, subphylum Vertebrata (except human beings) - has been reviewed by the Institute Butantan Animal Care and Use Committee and approved in $12 / 11 / 2013$. This proposal is in accordance with standards outlined by Brazilian laws for use of experimental animals, and with ethical principles adopted by the Brazilian College of Animal Experimentation.

\begin{tabular}{|c|c|c|}
\hline $\begin{array}{c}\text { Vigência do Projeto: } \\
10 / 2011-02 / 2014\end{array}$ & $\mathbf{N}^{*}$ de animais/espécie & Observaçåo \\
\hline $\begin{array}{c}\text { Laboratorio Especial de } \\
\text { Toxinologia Aplicada }\end{array}$ & $\begin{array}{c}552 \text { ratos Wistar }(\mathrm{M}) ; \\
268 \text { camundongos Swiss }(M)\end{array}$ & Alteraçào de vigência \\
\cline { 2 - 3 }
\end{tabular}

São Paulo, 12 de dezembro de 2013

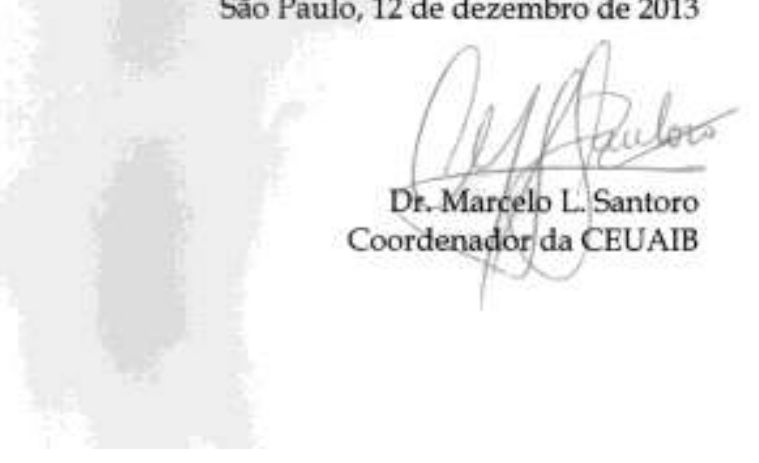


Aos meus pais, que devo tudo o que sou e que sempre me apoiaram em todas as minhas realizações.

Ao amor da minha vida, que sempre me ajudou e me apoiou me dando força e alegria nos momentos mais difíceis.

A todos os Mestres que sempre me ensinaram e muito colaboraram para minha formação.

A Enzo Gabriel, que me mostrou que nada somos se não lutarmos até o fim pelo que nos há de mais importante, a própria vida.

A minha avó Izabel, por todo o amor dedicado a minha pessoa e que sempre estará guiando meus passos.

A todos que me ajudaram, muito obrigado! 


\section{AGRADECIMENTOS}

Agradeço a Deus e seus mentores por sempre me guiarem em todos os passos da minha vida, por colocarem em meu caminho lições importantes e pessoas preciosas, enfim, tudo aquilo que me fez ser quem sou hoje.

Agradeço a meu pai Walter, por tudo o que me ensinou sobre valores, sobre bondade e amizade, por sempre me ajudar muito e me apoiar em todas as minhas decisões e formação, por todo o carinho e apesar de todos os acontecimentos, saiba que sempre o amarei muito. A minha mãe Oneide, por todo o seu exemplo, amor e dedicação, me mostrando o valor do trabalho em todas as minhas realizações, obrigado por tudo o que tem feito por mim, amo-te muito. A minha irmã Bárbara, por todo o apoio. A Emilianne, meu grande amor, saiba que sem toda a sua ajuda nada disso seria possível, obrigado por existir em minha vida, por me auxiliar em minhas caminhadas, por me amar, por tudo que me faz feliz. A minha tia Eliana, minha segunda mãe, que sempre me ajudou e me devolveu a alegria nos momentos mais difíceis. A meu padrinho Gerson ("Dunga"), que sempre me auxiliou em minha vida e que é um grande responsável por mais essa realização. Aos meus grandes amigos e praticamente irmãos: Eric, Douglas, Daniel e Carlos por toda a ajuda em todos estes anos de amizade. A minha avó Izabel, por todo o amor e dedicação prestados em toda a minha vida. A toda minha família e Irmãos de fé, meu muito obrigado.

Obrigado a todos os meus Mestres, da "tia" Cláudia que me ensinou a ler, a todos aqueles que passaram pela minha vida e colaboraram de alguma forma para minha formação. Muito obrigado a minha orientadora Dra. Vanessa Rioli, pela oportunidade dada e que sempre me ensinou muito e acreditou em mim. A Dra. Fernanda Calheta Vieira Portaro, por todos os ensinamentos e ajuda nos momentos mais difíceis, muito obrigado por me motivar em todas as situações que necessitei. Aos colaboradores, Dr. Fabio Gozzo e sua aluna Mariana Fioramonte da UNICAMP, por toda a ajuda prestada em relação à espectrometria de massas, ao Dr. Robson Lopes de Melo do Instituto Butantan, pela síntese dos peptídeos, ao Dr. Emer Suavinho Ferro e a Leandro Mantovani de Castro da USP, por todo auxílio durante o trabalho e pelos experimentos de quantificação por fluorescamina, a Dra. Gisele Picolo pelos experimentos relacionados à nocicepção e ao Dr. Luís Roberto C. Gonçalves pelos experimentos relacionados ao rolamento de leucócitos e reatividade vascular, todos do Instituto Butantan. Aos membros da minha banca de qualificação, Dra. Maria Regina Lopes 
Sandoval, Dra. Adriana Rios Lopes e Dr. Vitor Marcelo Silveira Bueno Brandão de Oliveira, pelas contribuições para a melhoria do trabalho.

Agradeço a Alexandre Kuniyoshi e Daniela Cajado, pela amizade e por toda a ajuda e participação direta nesse trabalho, que originou muitas aventuras.

Agradeço a todos do LETA e do CAT, que sempre de alguma forma me ajudaram, tornando possível a realização dos experimentos e dessa dissertação, em especial a Mariana Morone ("Mari”), Ivan Novaski ("Polaco") e Ismael Feitosa ("Chatão"), pela amizade e assistência nas horas mais difíceis. A todos os alunos do laboratório que sempre me apoiaram, o meu muito obrigado.

A CAPES e a FAPESP pelo apoio financeiro. 
"Nunca desista! Por mais que falem, por mais que se machuque, por mais que caia. Seja surdo, cure-se, levante-se, pois aquilo que com amor é feito, sempre o levará a vitória e ao caminho do bem". 


\section{RESUMO}

DUZZI, B. Busca de novos substratos e/ou inibidores das enzimas timet oligopeptidase (E.C.3.4.24.15) e neurolisina (E.C.3.4.24.16) nas frações de baixa massa molecular do veneno do escorpião Tityus serrulatus. 2014. 93f. Dissertação (Mestrado em Biotecnologia) - Instituto de Ciências Biomédicas, Universidade de São Paulo, São Paulo, 2014.

Acidentes por escorpiões são considerados um grave problema de saúde pública no Brasil, onde segundo o SINAN representaram aproximadamente $45 \%$ dos casos notificados de acidentes causados por animais peçonhentos. A espécie Tityus serrulatus é a maior representante das fatalidades decorridas. Os principais sintomas apresentados pelos acidentados mais graves são: dor, inflamação, febre, agitação psicomotora, salivação excessiva, lacrimação, aumento da motilidade gastrintestinal, arritmia cardíaca e respiratória, hipertensão arterial seguida de hipotensão, insuficiência cardíaca e choque. Apesar da potência de seu veneno, o que atualmente se conhece sobre seus componentes moleculares são, principalmente, as neurotoxinas que agem em canais iônicos, além de poucas informações sobre outros peptídeos biologicamente ativos. Neste estudo analisamos o veneno de Tityus serrulatus como fonte de peptídeos que interagissem com metalopeptidases de importância fisiopatológica, como as oligopeptidases neurolisina (EP 24.16) e timet oligopeptidase (EP 24.15), além da enzima conversora de angiotensina I (ECA) e neprilisina (EP 24.11). Estas enzimas foram especialmente selecionadas por serem relacionadas aos quadros clínicos observados após a picada (dor, inflamação, problemas cardiovasculares). Utilizando-se a fração de baixa massa molecular do veneno foram selecionadas frações testadas através do emprego de substratos FRET (Fluorescence Resonance Energy Transfer) específicos e as oligopeptidases recombinantes selvagens, onde foram determinadas por espectrometria de massas as sequências primárias dos seguintes peptídeos: FTR, KEILG e YLPT. Os peptídeos foram sintetizados para testes, incluindo um análogo de sequência KELLG. Nos testes in vitro, nenhum dos peptídeos se comportou como substrato e, portanto, foram submetidos a testes cinéticos para as determinações dos mecanismos de inibição e das constantes de inibição (Ki). A EP 24.15 foi inibida pelos peptídeos KELLG, KEILG, FTR e bem fracamente pelo YLPT. A EP 24.16 foi inibida pelo FTR e YLPT, não apresentando inibição perante aos peptídeos KELLG e KEILG. Este fato chamou muito a atenção, pois estes dois peptídeos agiram como um diferencial em relação às oligopeptidases EP 24.15 e EP 24.16, detentoras de estruturas e atividades similares. Outra enzima testada foi a ECA, porém nenhum dos quatro peptídeos foi capaz de inibi-la. Em relação à EP 24.11, o peptídeo KEILG não foi capaz de causar inibição, o KELLG foi capaz de inibi-la fracamente, FTR e YLPT inibiram de forma mais eficaz a enzima. Em experimentos in vivo, para avaliar atividade antinociceptiva foram realizados inicialmente testes com os peptídeos no modelo de pressão de pata de ratos. Dentre todos os peptídeos avaliados, somente o FTR, foi capaz de acarretar efeito antinociceptivo. Ensaios realizados sobre a reatividade vascular e alterações na interação leucócito-endotélio induzidas pelos peptídeos na microcirculação do músculo cremaster de camundongos, demonstraram que o peptídeo KEILG foi capaz de aumentar o número de leucócitos. Portanto neste estudo identificamos, pela primeira vez, peptídeos oriundos do veneno do $T$. serrulatus capazes de interagir com as oligopeptidases. Nossos resultados apontaram diferenças na interação das enzimas com os peptídeos que as inibiram. Além disso, os dados indicam que KELLG e KEILG podem ser moléculas usadas para gerar modulações na atividade enzimática das oligopeptidases.

Palavras-chave: Tityus serrulatus. Escorpião amarelo. Componentes do veneno. Peptídeos. Oligopeptidases. EP 24.15. EP 24.16. 


\begin{abstract}
DUZZI, B. Search for new substrates and / or inhibitors of thimet oligopeptidase (EC3.4.24.15) and neurolysin (EC3.4.24.16) enzymes in low molecular weight fractions of Tityus serrulatus scorpion venom. 2014. 93p. Dissertation (Masters thesis in Biotechnology) - Instituto de Ciências Biomédicas, Universidade de São Paulo, São Paulo, 2014.
\end{abstract}

Envenomation caused by scorpions represents a serious public health problem in Brazil. According to SINAN, approximately $45 \%$ of all reported cases of accidents by venomous animals are caused by scorpions. Tityus serrulatus is the species that causes most accidents, and, in severe cases the main symptoms reported are: pain, inflammation, fever, psychomotor agitation, excessive salivation, lacrimation, increased gastrointestinal motility, cardiac and respiratory arrhythmia, hypotension followed by hypertension, heart failure, pulmonary edema and cardiogenic shock. Despite the medical importance of $T$. serrulatus, the knowledge about its venom proteome is limited to the neurotoxins acting on ion channels, and little information about other biologically active peptides is available. This study analyzed the $T$. serrulatus venom as a source of peptides that interact with metallopeptidases of pathophysiological importance, such as neurolysin (EP 24.16), thimet oligopeptidase (EP 24.15), angiotensin converting enzyme (ACE) and neprilysin (EP 24.11). These enzymes were specially selected because they can be clinically related to the symptoms observed after the scorpion bite (pain, inflammation and cardiovascular problems). Using the low molecular mass fraction of the venom, peptides were selected through a screening with FRET (Fluorescence Resonance Energy Transfer) substrates and recombinant wild type oligopeptidases. The amino acid sequences of active components were identified by mass spectrometry, resulting in the peptides: FTR, KEILG and YLPT. These peptides were synthesized, including an analog peptide, KELLG. The in vitro tests revealed that none of the peptides was substrate of the oligopeptidases and, therefore, assays to determine the mechanism of inhibition and kinetic constants $(\mathrm{Ki})$ were performed. The results showed that EP 24.15 was significantly inhibited by peptides KELLG, KEILG, FTR and weakly affected by YLPT. EP 24.16 was inhibited by FTR and YLPT, and showed no inhibition by the peptides KELLG and KEILG. These data indicate that peptides KELLG and KEILG interacted with EP 24.15 but not with EP 24.16, and therefore are capable of discriminating between these oligopeptidases, which have similar structures and activities. Interestingly, ACE was not inhibited by the four peptides indicating that. Regarding EP 24.11, KEILG and KELLG were able to weakly inhibit it but YLPT and FTR were more effective inhibitors. In vivo experiments to evaluate the antinociceptive activity of these peptides were performed using Randall and Selitto tests. With the exception of the FTR, which demonstrated antinociceptive effect in rats, none of the other peptides were able to cause any effect. The evaluation of the effect of these peptides on the microcirculation of the cremaster muscle in mice revealed that only KEILG was able to increase the number of rolling leukocyte. In conclusion, in this study we identified for the first time $T$. serrulatus venom peptides that were able to interact with oligopeptidases. Our results also pointed out differences in the interaction of these enzymes with peptides leading to their inhibition. Moreover, these data indicate that KELLG and KEILG could be lead molecules to generate modulators of olipeptidase enzymatic activities.

Keywords: Tityus serrulatus. Yellow scorpion. Venom components. Peptides. Oligopeptidases. EP 24.15. EP 24.16. 


\section{LISTA DE FIGURAS}

Figura 1 - Representação da Deusa Serket (A) e do Rei Escorpião II (B) ............................20

Figura 2 - Morfologia do escorpião .............................................................................22

Figura 3 - Mapa com a distribuição geográfica das três principais espécies

responsáveis pelos acidentes no Brasil: T. serrulatus, T. bahiensis e T. stigmurus .................26

Figura 4 - Representação do número de acidentes registrados no SINAN em 2011 ............27

Figura 5 - Classificação dos casos de escorpionismo no Brasil em 2011 ..............................28

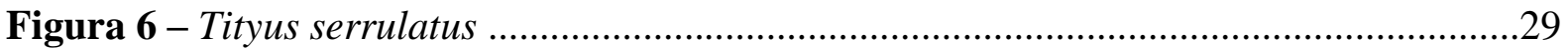

Figura 7 - Estrutura da timet oligopeptidase (EP 24.15) e neurolisina (EP 24.16) ................35

Figura 8 - Esquema da captura de peptídeos utilizando enzimas cataliticamente inativas por

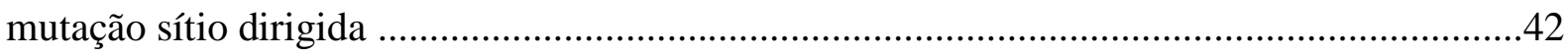

Figura 9 - Gel da expressão das enzimas empregadas nos experimentos .............................49

Figura 10 - Cromatograma da interação da fração de baixa massa molecular do veneno de Tityus serrulatus com as enzimas inativas EP24. 15 e EP24. 16 ...........................................51

Figura 11 - Novo cromatograma da interação da fração de baixa massa molecular do veneno de Tityus serrulatus com as enzimas inativas EP 24.16

Figura 12 - Junção das frações provenientes dos experimentos empregando 100 e $150 \mu \mathrm{g}$ de

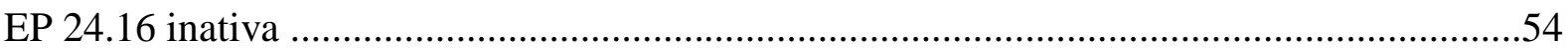

Figura 13 - Figura 11 A adaptada para demonstração das regiões correspondentes ..............54

Figura 14 - Quadro comparando as frações da Figura 12 em relação à Figura 13 .................55

Figura 15 - Quadro com as massas obtidas e selecionadas por MS/MS das frações analisadas.

Figura 16 - Espectro de massas do peptídeo XXSAF encontrado no P13 proveniente doscreening por atividade enzimática .56

Figura 17 - Espectro de massas do peptídeo FTR encontrado na amostra 4 (Figura 12) referente ao pico A (Figura 13) .56

Figura 18 - Cromatograma da fração de baixa massa molecular do veneno do $T$. serrulatus após HPLC em fase-reversa C-18 (Shimadzu, Prominence)

Figura 19 - Porcentagem de inibição relativa das atividades enzimáticas da EP 24.15 e da EP 24.16

Figura 20 - Cromatograma das frações selecionadas com diferentes gradientes para uma melhor separação ("abertura" dos picos obtidos) 
Figura 21 - Porcentagem de inibição das novas frações coletadas provenientes da "abertura" dos picos perante a inibição da enzima EP 24.16 selvagem

Figura 22 - Inibição das amostras 6P, 6P1 e 6P2 em relação à EP 24.16 recombinante selvagem

Figura 23 - Espectro dos peptídeos encontrados na fração 6P1

Figura 24 - Quadro contendo diferentes concentrações dos peptídeos e suas inibições em relação a cada enzima testada .63

Figura 25 - Quadro relacionando o tipo de mecanismo de inibição e Ki (constante de inibição) dos peptídeos perante as enzimas

Figura 26 - Limiar de dor X tempo de tratamento após o pico de ação da Carragenina ........65

Figura 27 - Injeção do peptídeo FTR com a presença da Carragenina .................................65

Figura 28 - Injeção do peptídeo FTR sem a presença da Carragenina ...................................66

Figura 29 - Relação entre o número de leucócitos em rolamento por minuto dos peptídeos

KEILG e KELLG .67 


\section{LISTA DE ABREVIATURAS E SIGLAS}

ACN - Acetonitrila

ANP - Peptídeo natriurético atrial

BK - Bradicinina

BNP - Peptídeo natriurético cerebral

cDNA - DNA complementar

CEUAIB - Comissão de Ética no Uso de Animais do Instituto Butantan

CGEN - Conselho de Gestão do Patrimônio Genético

COBEA - Colégio Brasileiro de Experimentação Animal

ECA - Enzima conversora de angiotensina

EP 24.11 - Neprilisina

EP 24.15 - Timet oligopeptidase

EP 24.16 - Neurolisina

FRET - "Fluorescense Resonance Energy Transfer"

GABA - "Gamma-Aminobutyric Acid"

HPLC - "High Performance Liquid Chromatography"

IPTG - Isopropil- $\beta$-D-1-tiogalactopiranosídeo

$\mathrm{Ki}$ - Constante de inibição

$\mathrm{Ki}(\mathrm{app})$ - Constante de inibição aparente

$\mathrm{Km}$ - Constante de Michaelis-Menten

LC-MS/MS - "Liquid chromatography-mass spectrometry/mass spectrometry"

LETA - Laboratório Especial de Toxinologia Aplicada

PAPE - Fragmentos de sequência tetrapeptídica Pro-Ala-Pro-Glu de repetição em tanden

PBS - Tampão Fosfato Salino

QFS - "Quenched Fluorescense Substrate"

SINAN - Sistema de Informação de Agravos de Notificação

TBS - Tampão Tris Salino

TFA - Ácido trifluoroacético

UNICAMP - Universidade Estadual de Campinas

YLPT - desArg-Proctolin 


\section{LISTA DE ABREVIATURAS DE AMINOÁCIDOS}

$\begin{array}{ccc}\text { Aminoácido } & \text { Abreviatura (3 letras) } & \text { Abreviatura (1 letra) } \\ \text { Alanina } & \text { Ala } & \mathrm{A} \\ \text { Arginina } & \text { Arg } & \mathrm{R} \\ \text { Asparagina } & \text { Asn } & \mathrm{N} \\ \text { Aspartato } & \text { Asp } & \mathrm{D} \\ \text { Cisteína } & \text { Cys } & \mathrm{C} \\ \text { Fenilalanina } & \text { Phe } & \mathrm{F} \\ \text { Glicina } & \text { Gly } & \mathrm{G} \\ \text { Glutamato } & \text { Glu } & \mathrm{E} \\ \text { Glutamina } & \text { Gln } & \mathrm{Q} \\ \text { Histidina } & \text { His } & \mathrm{H} \\ \text { Isoleucina } & \text { Ile } & \mathrm{I} \\ \text { Leucina } & \text { Leu } & \mathrm{L} \\ \text { Lisina } & \text { Lys } & \mathrm{K} \\ \text { Metionina } & \text { Met } & \mathrm{M} \\ \text { Prolina } & \text { Pro } & \mathrm{P} \\ \text { Serina } & \text { Ser } & \mathrm{S} \\ \text { Tirosina } & \text { Tyr } & \mathrm{Y} \\ \text { Treonina } & \text { Thr } & \mathrm{T} \\ \text { Triptofano } & \text { Val } & \mathrm{V} \\ \text { Valina } & & \end{array}$




\section{SUMÁRIO}

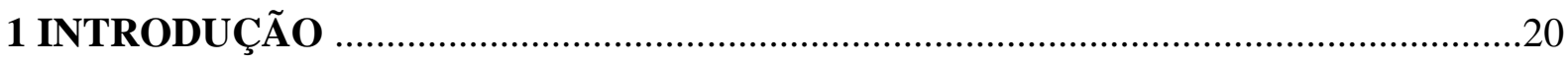

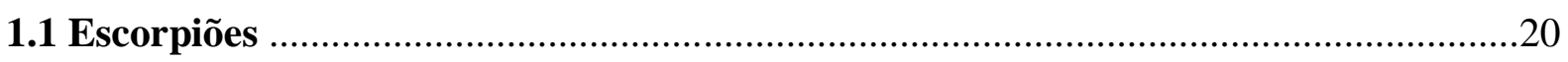

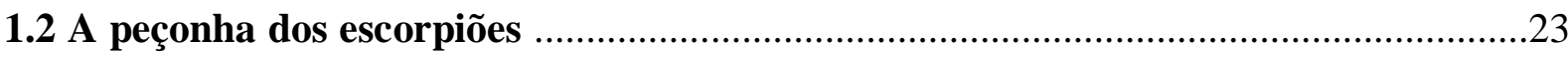

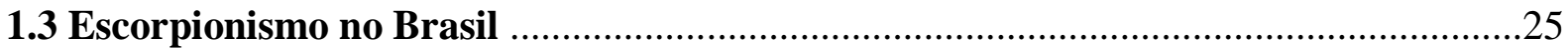

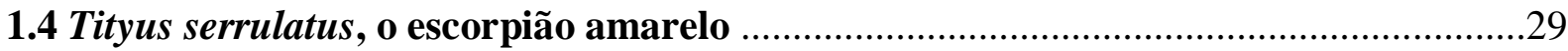

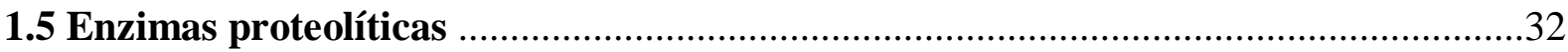

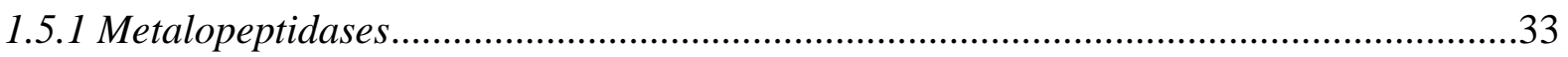

1.5.2 Timet oligopeptidase (EP 24.15), neurolisina (EP 24.16), neprilisina (EP 24.11),

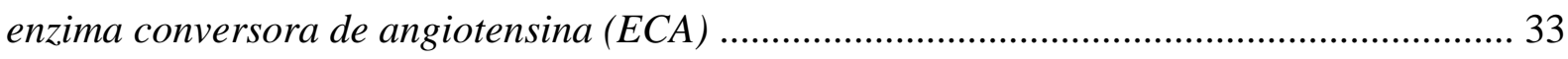

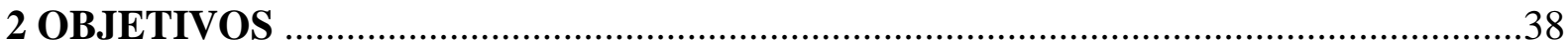

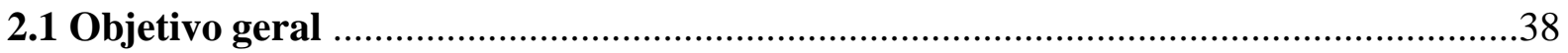

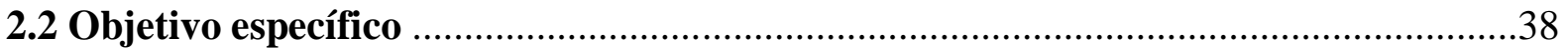

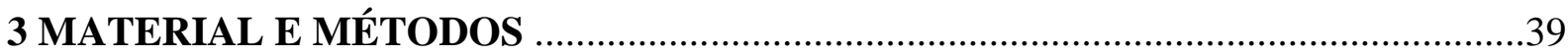

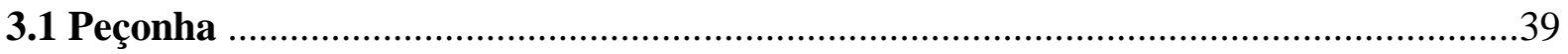

3.2 Expressão das enzimas timet oligopeptidases (EP 24.15) e neurolisina EP 24.16 recombinantes selvagens e mutantes cataliticamente inativas E474A e E475A respectivamente

3.3 Fracionamento da peçonha do Tityus serrulatus para a obtenção da fração de baixa massa molecular

3.4 Quantificação do pool peptídico de baixa massa molecular da peçonha do $T$. serrulatus através do emprego da fluorescamina

3.5 Isolamento dos possíveis substratos e/ou inibidores peptídicos das enzimas timet oligopeptidases (EP 24.15) e neurolisina (EP 24.16) cataliticamente inativas a partir da fração de baixa massa molecular

3.6 Junção das amostras provenientes do experimento de captura de peptídeos com 100 e $150 \mu$ g de neurolisina (EP 24.16) inativa, obtenção do perfil cromatográfico por HPLC, fracionamento e coleta manual

3.7 Screening das frações peptídicas por atividade moduladora das enzimas timet oligopeptidase (EP 24.15) e neurolisina (EP 24.16) selvagens ......................................44 3.8 Sequenciamento dos peptídeos por espectrometria de massas (LC-MS/MS) ...........44

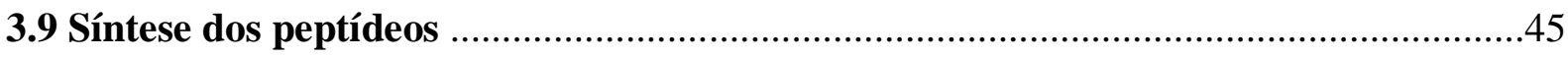


3.10 Testes para a identificação de substratos dentre os peptídeos sintetizados perante as enzimas timet oligopeptidases (EP 24.15), neurolisina (EP 24.16), neprilisina (EP 24.11) e enzima conversora de angiotensina ECA

3.11 Testes cinéticos para a determinação de inibidores da atividade enzimática das enzimas timet oligopeptidases (EP 24.15), neurolisina (EP 24.16), neprilisina (EP 24.11) e enzima conversora de angiotensina (ECA)

3.12 Possíveis alterações da sensibilidade dolorosa induzida por novos substratos e/ou inibidores para timet oligopeptidases (EP 24.15) e neurolisina (EP 24.16) obtidos das frações de baixa massa molecular do veneno do escorpião Tityus serrulatus

3.12.1 Animais

3.12.2 Ensaios de nocicepção

3.12.3 Inflamação: Reatividade vascular e alterações na interação leucócito-endotélio induzidas pelos peptídeos da peçonha do Tityus serrulatus na microcirculação do músculo cremaster de camundongos

4 RESULTADOS

4.1 Expressão das enzimas timet oligopeptidases (EP24.15) e neurolisina (EP24.16) recombinantes selvagens e cataliticamente inativas e testes para a determinação da atividade enzimática

4.2 Fracionamento da peçonha do Tityus serrulatus para a obtenção da fração de baixa massa molecular e quantificação do pool peptídico empregando fluorescamina .50

4.3 Isolamento dos possíveis substratos e/ou inibidores peptídicos das enzimas timet oligopeptidases (EP 24.15) e neurolisina (EP 24.16) a partir da fração de baixa massa molecular

4.3.1 Técnica de captura de peptídeos com o emprego das enzimas timet oligopeptidases EP

24.15 e neurolisina (EP 24.16) cataliticamente inativas

4.3.2 Emprego da técnica de captura de peptídeos com a enzima neurolisina (EP 24.16) cataliticamente inativa

4.3.3 Isolamento de peptídeos através da interação com as oligopeptidases selvagens e emprego de substratos FRETs

4.4 Sequenciamento dos peptídeos provenientes dos experimentos com a neurolisina (EP 24.16) selvagem e cataliticamente inativa por espectrometria de massas (LC-MS/MS) .60 4.5 Síntese dos peptídeos 
4.6 Testes para a identificação de substratos dentre os peptídeos sintetizados perante as enzimas timet oligopeptidases (EP 24.15), neurolisina (EP 24.16), neprilisina (EP 24.11) e enzima conversora de angiotensina (ECA)

4.7 Testes para a identificação de inibidores dentre os peptídeos sintetizados perante as enzimas timet oligopeptidases (EP 24.15), neurolisina (EP 24.16), neprilisina (EP 24.11) e enzima conversora de angiotensina (ECA)

4.8 Determinação do mecanismo e constante de inibição $(\mathrm{Ki})$ dos peptídeos em relação às enzimas timet oligopeptidases (EP 24.15), neurolisina (EP 24.16), neprilisina (EP 24.11) e enzima conversora de angiotensina (ECA)

4.9 Possíveis alterações da sensibilidade dolorosa induzida por inibidores para timet oligopeptidases (EP 24.15) e neurolisina (EP 24.16) obtidos das frações de baixa massa molecular do veneno do escorpião Tityus serrulatus

4.9.1 Ensaios de nocicepção

4.9.2 Inflamação: Reatividade vascular e alterações na interação leucócito-endotélio induzidas pelos peptídeos da peçonha do Tityus serrulatus na microcirculação do músculo cremaster de camundongos . .66

5 DISCUSSÃO . .68

6 CONCLUSÕES .78

REFERÊNCIAS 79

APÊNDICE A - Insights into scorpion venom peptides: alternative processing of $\beta$-KTx propeptide from Tityus serrulatus venom results in a new naturally occurring thimet oligopeptidase inhibitor 


\section{INTRODUÇÃO}

\subsection{Escorpiões}

Os escorpiões são organismos que há tempos intrigam os seres humanos. Registros históricos são encontrados em tumbas e monumentos de antigos povoados do Oriente e do Mediterrâneo. No Egito Antigo, o respeito e admiração pela figura do escorpião são bem descritos, onde registros em papiro confirmam mitos, conselhos relacionados à sua peçonha e ainda cuidados para tratamento de acidentados. O escorpião foi responsável pela nomeação de uma dinastia de reis, além de compor uma divindade do panteão egípcio (Serket), a deusa que guarda o corpo e as vísceras dos mortos e que os acompanham em sua jornada para outra vida (Figura 1) (EL-HENNAWY, 2011).

Figura1 - Representação da Deusa Serket (A) e do Rei Escorpião II (B)
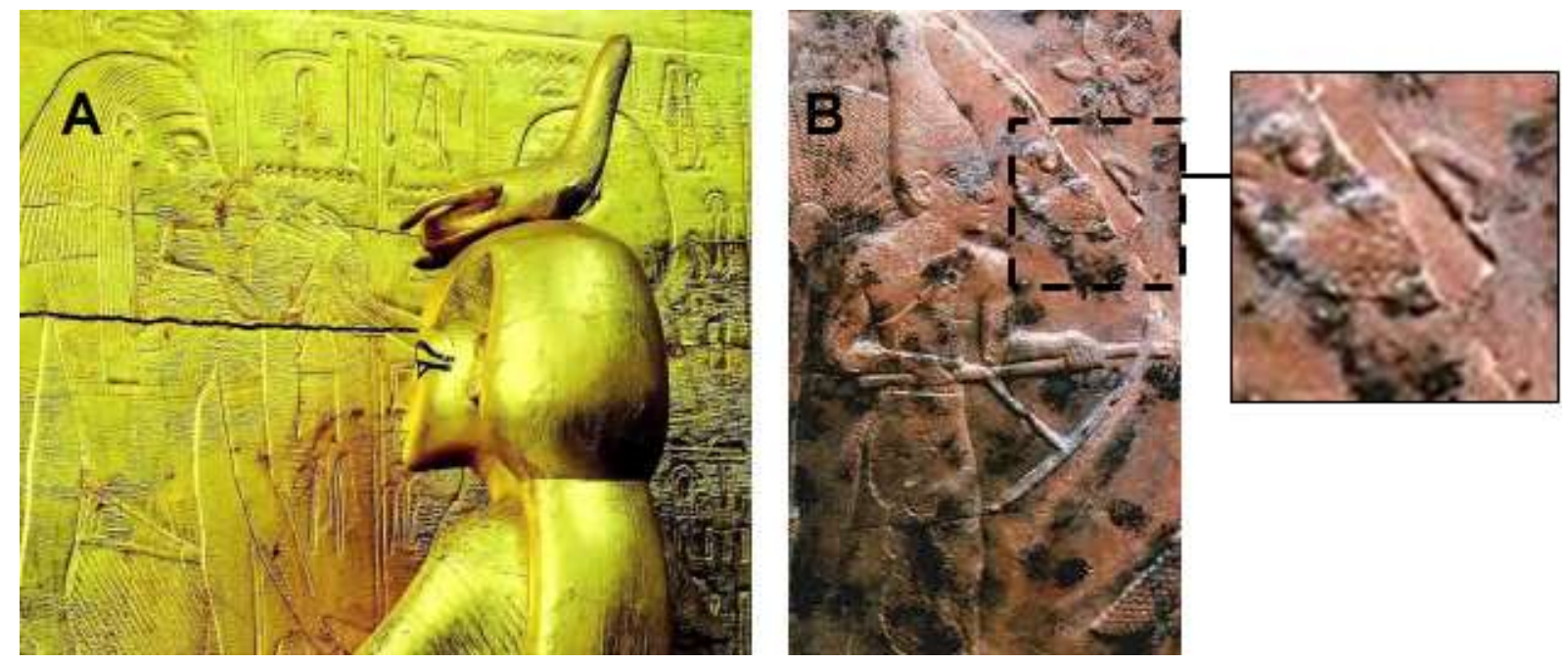

Figuras adaptadas de EL-HENNAWY, 2011. (A) Serket, a "Deusa Escorpião" do Antigo Egito. Acreditava-se que era responsável por guardar as vísceras e o corpo dos mortos em sua jornada para outra vida (Peça do Museu Egípcio do Cairo). (B) Representação do Rei Escorpião II, Dinastia 0 Hierakonpolis, 3100 a.C. (Museu Ashmolean de Oxford). Em destaque na ampliação a figura do escorpião.

Os escorpiões são artrópodes quelicerados, apontados com um dos primeiros seres de origem aquática a conquistarem o meio terrestre (CARDOSO, 2009). Sua origem data o período carbonífero, há mais de 400 milhões de anos. Apontados como um dos aracnídeos mais antigos existentes na Terra são animais que possuem anos de evolução (BORTOLUZZI et al., 2007; CARDOSO, 2009). São carnívoros e se alimentam de insetos como grilos e baratas, exercendo suas caçadas durante a noite (FUNASA, 1998). 
A ordem Scorpiones é representada por mais de 1500 espécies conhecidas e distribuídas em todos os continentes, exceto na Antártida. Por conta desta distribuição, estes animais vivem na maioria dos habitats terrestres, desde florestas tropicais até regiões mais áridas (BORTOLUZZI et al., 2007; CARDOSO, 2009; POSSANI et al., 1999).

Durante muito tempo os escorpiões foram tratados como animais generalistas em relação ao seu habitat. Porém este conceito foi mudado pelo fato de muitos precisarem de habitats e ambientes específicos para sua sobrevivência. As espécies consideradas generalistas, muitas vezes são encontradas em ambientes modificados pelo homem e geralmente são responsáveis pelos acidentes ocorridos. As espécies especialistas, em sua maioria, apresentam uma única prole e não realizam estocagem de esperma, a capacidade de crescimento de sua população é fraca com baixas densidades e capacidade de dispersão. Já as espécies generalistas, como a Tityus, possuem períodos embrionários e pós-embrionários curtos, assim como uma vida mais longa, se comportando de maneira contrária as especialistas, principalmente no que se diz respeito à distribuição e dispersão populacional, representando mais um fator de risco relacionado aos acidentes (LOURENÇO et al., 2003).

Estudos taxonômicos do final da década de 1970 relataram a existência de seis famílias de escorpiões. Na década de 1980 este número subiu para nove e recentemente, foram catalogadas 20 famílias e 165 gêneros (LOURENÇO et al., 2003). Os escorpiões mais perigosos e capazes de causarem acidentes fatais em seres humanos pertencem à família Buthidae, sendo representada pelos gêneros Androctonus e Leiurus (África do Norte e Oriente Médio), Centruroides (México e Estados Unidos) e Tityus (América do Sul e Trinidad) (LOURENÇO et al., 2003). As toxinas mais potentes desta família são de grupos genéricos considerados mais ancestrais, onde a evolução da toxicidade se deu independentemente de outras características, por linhagens que passaram por um número maior de substituições genéticas com o passar dos anos (LOURENÇO et al., 2003).

Em relação à morfologia escorpiônica (Figura 2), o corpo é dividido em duas partes: cefalotórax ou prossoma e o abdome, o qual se segmenta em 12 metâmeros. Os 7 primeiros formam o mesossoma e os 5 restantes formam o metassoma ou cauda. Após o último segmento do metassoma vem o telson, onde se alojam 2 glândulas de veneno. O prossoma é recoberto dorsalmente pela placa prossomial que contem 2 olhos medianos e geralmente de 2 a 5 pares de olhos laterais. No prossoma se encontram 4 pares de pernas e na parte anterior um par de pedipalpos e um par de quelíceras. Ventralmente no prossoma é encontrado um orifício genital e um par de pentes (apêndices exclusivos dos escorpiões). Nos esternitos do mesossoma são encontrados 4 pares de aberturas respiratórias (POLIS, 1990). 
Os escorpiões possuem um esqueleto externo quitinoso que reveste seu corpo. $\mathrm{O}$ exoesqueleto protege os órgãos internos, e é a base de sustentação e de vários receptores sensitivos, espiráculos e outras estruturas de comunicação com meio externo. Possuem internamente cinco sistemas fisiológicos: nervoso, circulatório, respiratório, reprodutivo e digestivo (POLIS, 1990).

Figura 2 - Morfologia do escorpião

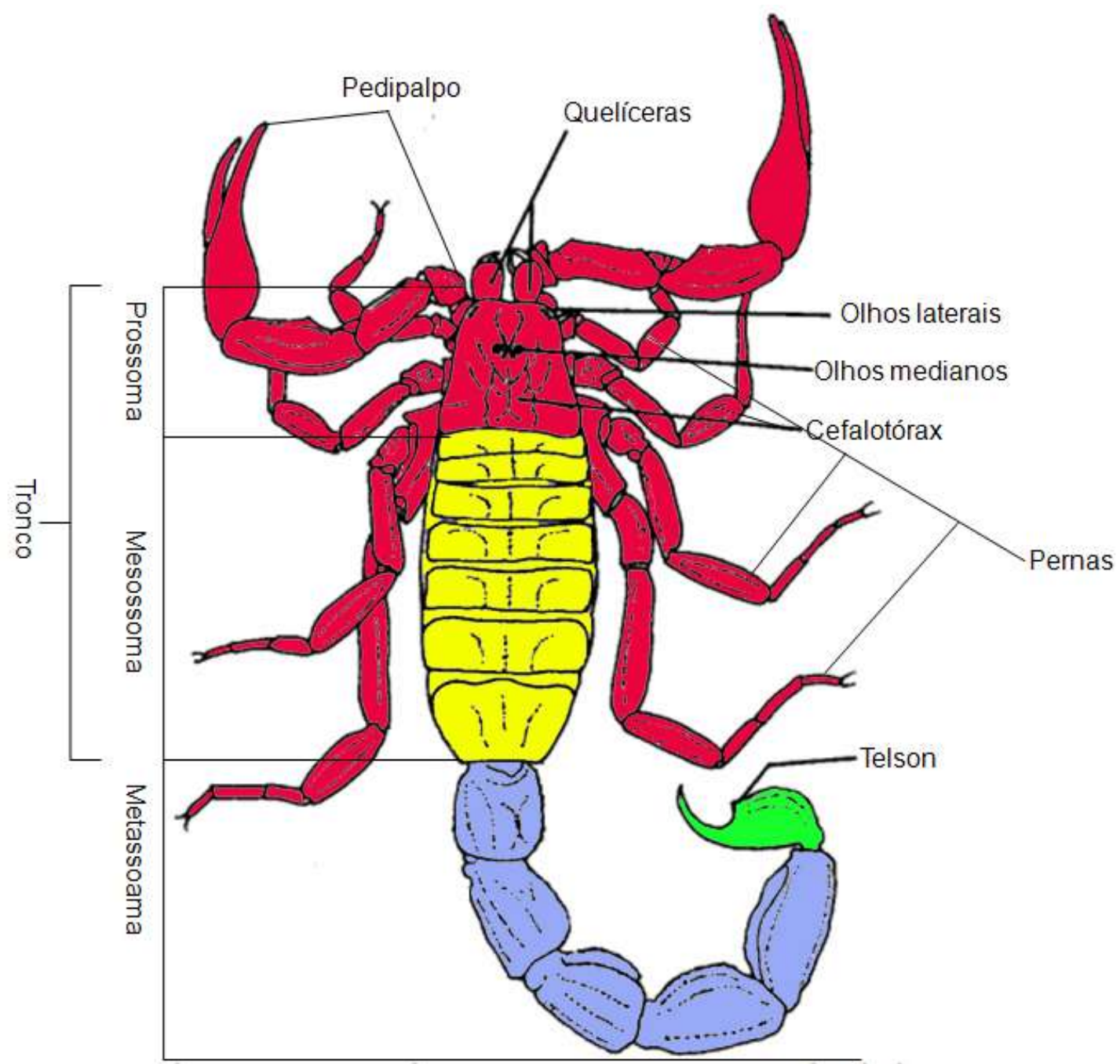

Adaptado de POLIS, 1990. Vista dorsal do escorpião Hottentotta hottentotta. As regiões em destaque são: Prossoma (em vermelho), Mesossoma (em amarelo), Metassoma (em azul) e Telson (em verde). 


\subsection{A peçonha dos escorpiões}

Peçonhas são misturas de substâncias tóxicas, produzidas em um grupo de células especializadas, órgãos secretórios ou glândulas conectadas ao dispositivo de injeção (FREITAS, 1991). Os estudos relacionados às peçonhas de escorpiões são realizados geralmente com as espécies responsáveis pelos acidentes mais graves e de maior importância para a saúde pública.

A peçonha dos escorpiões é composta de uma mistura complexa de componentes de origem apócrina, produzida por um par de glândulas exócrinas altamente especializadas (YAMAJI et al., 2004). Dentre os componentes podemos citar enzimas, lipídeos, nucleotídeos, aminas biogênicas, peptídeos e vários outros compostos ainda não identificados (BATISTA et al., 2004).

Diversos trabalhos mostram que a maioria dos efeitos farmacológicos das toxinas derivadas da peçonha de diferentes espécies de escorpiões é devido às ações sobre canais de sódio $\left(\mathrm{Na}^{+}\right)$e potássio $\left(\mathrm{K}^{+}\right)$, além de canais de cálcio $\left(\mathrm{Ca}^{2+}\right)$ e cloro $\left(\mathrm{Cl}^{-}\right)$. Os canais iônicos estão presentes em diferentes tipos celulares como neurônios, células musculares e células do sistema imune, sendo essenciais para a manutenção do equilíbrio eletrolítico do organismo. Eles são responsáveis pela geração de sinais elétricos para geração e condução do potencial de ação, necessários para condução do impulso nervoso, batimentos cardíacos, secreção hormonal, função renal e na ativação de células do sistema imune entre outros, além de participarem das vias de ativação intracelular dependentes de cálcio (CATTERALL et al., 2007). Assim, alguns efeitos causados pela peçonha de escorpião sobre o sistema nervoso central e coração, podem estar relacionados com as toxinas que atuam sobre estes canais.

Muitas destas toxinas têm contribuído nos estudos de caracterização dos canais iônicos em diferentes modelos celulares. Essas neurotoxinas agem através de diferentes mecanismos, provocando despolarização das membranas de diferentes células do organismo (revisado em CATTERALL et al., 2007). Animais e plantas de vários filos têm utilizado estes canais como alvos de potentes neurotoxinas como mecanismo de imobilização da presa por alteração dos sinais elétricos (CESTÈLE; CATTERALL, 2000).

As neurotoxinas de escorpião mais estudadas são as que atuam sobre canais de $\mathrm{Na}^{+} \mathrm{e}$ $\mathrm{K}^{+}$. A maioria das $\mathrm{Na}^{+}$toxinas são compostas de 61-70 aminoácidos, as $\mathrm{K}^{+}$-toxinas apresentam 31-39 aminoácidos, enquanto que a clorotoxina, específica para canal de $\mathrm{Cl}^{-}$ apresenta 36 resíduos. Todas elas têm sua estrutura estabilizada por 3 a 4 pontes dissulfeto (BECERRIL et al., 1997). 
Diversos estudos mostram o efeito de toxinas, ligantes de canais iônicos isoladas da peçonha de diferentes espécies de escorpiões sobre o sistema nervoso central. Estudos com veneno de $T$. serrulatus mostraram efeitos importantes sobre o sistema nervoso central de ratos quando injetados diretamente no hipocampo, que estão relacionados com uma molécula denominada TsTX-II (SANDOVAL; LEBRUN, 2003a).

Outras neurotoxinas com efeito analgésico foram descritas, como por exemplo, a toxina BmK ou AngM1 isolada do veneno de Buthus martensi Karch apresenta efeito antinociceptivo em camundongos (CAO et al., 2004). O peptídeo T, isolado do escorpião Tityus serrulatus, mostrou-se um agente potenciador da bradicinina (FERREIRA et al., 1993). Um dos peptídeos pertencentes a esta família e citado na literatura é o TsHpt-1, que apresentou atividade hipotensora em ratos normotensos, na sua forma nativa ou sintética, mesmo sem a presença da bradicinina, indicando outros mecanismos de ações desempenhados por este peptídeo (FERREIRA et al., 1993). Outras patologias têm sido alvo de interesse na aplicação terapêutica dessas toxinas. A clorotoxina, inicialmente caracterizada como específica para canais de cloro, já passou por ensaio clínico fase I para controle/diagnóstico de tumor maligno cerebral, o glioma, e está sendo atualmente testada em ensaio clínico fase II (MAMELAK; JACOBY, 2007). Os autores descrevem uma potente inibição da MMP-2 (metaloprotease humana de matriz-2) pela clorotoxina e indicam que os canais de cloro não são o principal alvo desta molécula. Peçonhas de algumas espécies de escorpião são capazes de induzir apoptose em alguns tipos celulares. Foi observado que a peçonha de Heterometrus bengalensis Koch é capaz de induzir a apoptose das linhagens leucêmicas humanas U937 e K562 (GUPTA et al., 2007). Outro veneno foi capaz de induzir apoptose da linhagem tumoral U251-MG de glioma humano Buthus martensi Karsch além de inibir o crescimento tumoral in vivo (WANG et al., 2005).

Também são descritos na peçonha dos escorpiões peptídeos que não apresentam pontes dissulfeto, geralmente se apresentam como moléculas contendo entre 13 e 56 aminoácidos e que apresentam atividade biológica não ligada a efeitos neurotóxicos, ao contrário da maioria dos peptídeos encontrados e que fazem pontes dissulfeto, que conseguem uma maior estabilidade molecular e com isso ultrapassar a barreira hematoencefálica ( ALMAAYTAH; ALBALAS, 2012; POSSANI et al., 1999). As atividades biológicas apresentadas por este grupo de peptídeos são diversas, como a potencialização da bradicinina pela inibição da enzima conversora de angiotensina (por exemplo, o peptídeo K12, isolado do escorpião Buthus occictanus); atividade antibacteriana (como o peptídeo Hadurin, isolado do escorpião Hadrurus aztecus), capaz de inibir em baixas concentrações o crescimento de 
bactérias Gram-positivas e Gram-negativas; atividade antifúngica (como o Opistoporim 1 isolado do escorpião sul-africano Opisoph-talmus carinatus); atividade antiviral (como o Hp1090 de 13 aminoácidos, isolado a partir da construção proveniente da biblioteca de cDNA da glândula do escorpião Heterometrus petersii); atividade antimalárica (como os peptídeos Meucin-24 e Meucin-25, isolados a partir da construção proveniente da biblioteca de cDNA da glândula do escorpião Mesobuthus eupeus); atividade anticâncer (como o peptídeo Mauriporin de 48 aminoácidos proveniente do escorpião Androctonus mauritanicus) e atividade imunomoduladora (como o Opistoporim 1), além de alguns outros peptídeos já descritos (ALMAAYTAH; ALBALAS, 2012). Portanto, o estudo destes peptídeos pode ajudar no surgimento de futuras drogas (HMED et al., 2013).

Os inúmeros estudos sobre a identificação de componentes das peçonhas de várias espécies de escorpiões mostram a diversidade de constituintes presentes com diversas atividades biológicas. No entanto, estudos mais recentes de análise proteômica têm sido realizados com o objetivo de melhor identificar a composição dessas peçonhas. Estudos de análise proteômica foram realizados com peçonhas de três espécies do gênero Tityus. As análises da peçonha total de $T$. discrepans identificaram componentes de 272-57.908 Da (BATISTA et al., 2007) e da peçonha de T.stigmurus componentes de 216.5 a $44.800 \mathrm{Da}$ (BATISTA et al., 2006). No entanto, a análise proteômica da peçonha de T. serrulatus foi realizada após cromatografia em gel filtração, onde foram estudados apenas os componentes abaixo de 7.500 Da (PIMENTA et al., 2001). Esse mesmo grupo mostrou ainda que existe uma variabilidade individual na composição do veneno dessa espécie (PIMENTA et al., 2003a; PIMENTA et al., 2003b). Portanto, apesar da grande quantidade de informação obtida nesses estudos, muito ainda precisa ser feito para identificar e caracterizar funcionalmente todos os componentes desses venenos.

\subsection{Escorpionismo no Brasil}

O escorpionismo é caracterizado como acidentes envolvendo os escorpiões e os seres humanos (LIRA-DA-SILVA et al., 2009). Os escorpiões mais perigosos no Brasil são do gênero Tityus. Embora quase 30 espécies deste gênero ocorram no Brasil, os principais causadores de acidentes são: T. serrulatus, T. bahiensis e T. stigmurus (FUNASA, 1998). A Figura 3 mostra a distribuição geográfica dos escorpiões responsáveis pelo maior número de acidentes no Brasil. 
Figura 3 - Mapa com a distribuição geográfica das três principais espécies responsáveis pelos acidentes no Brasil: T. serrulatus, T. bahiensis e $T$. stigmurus.

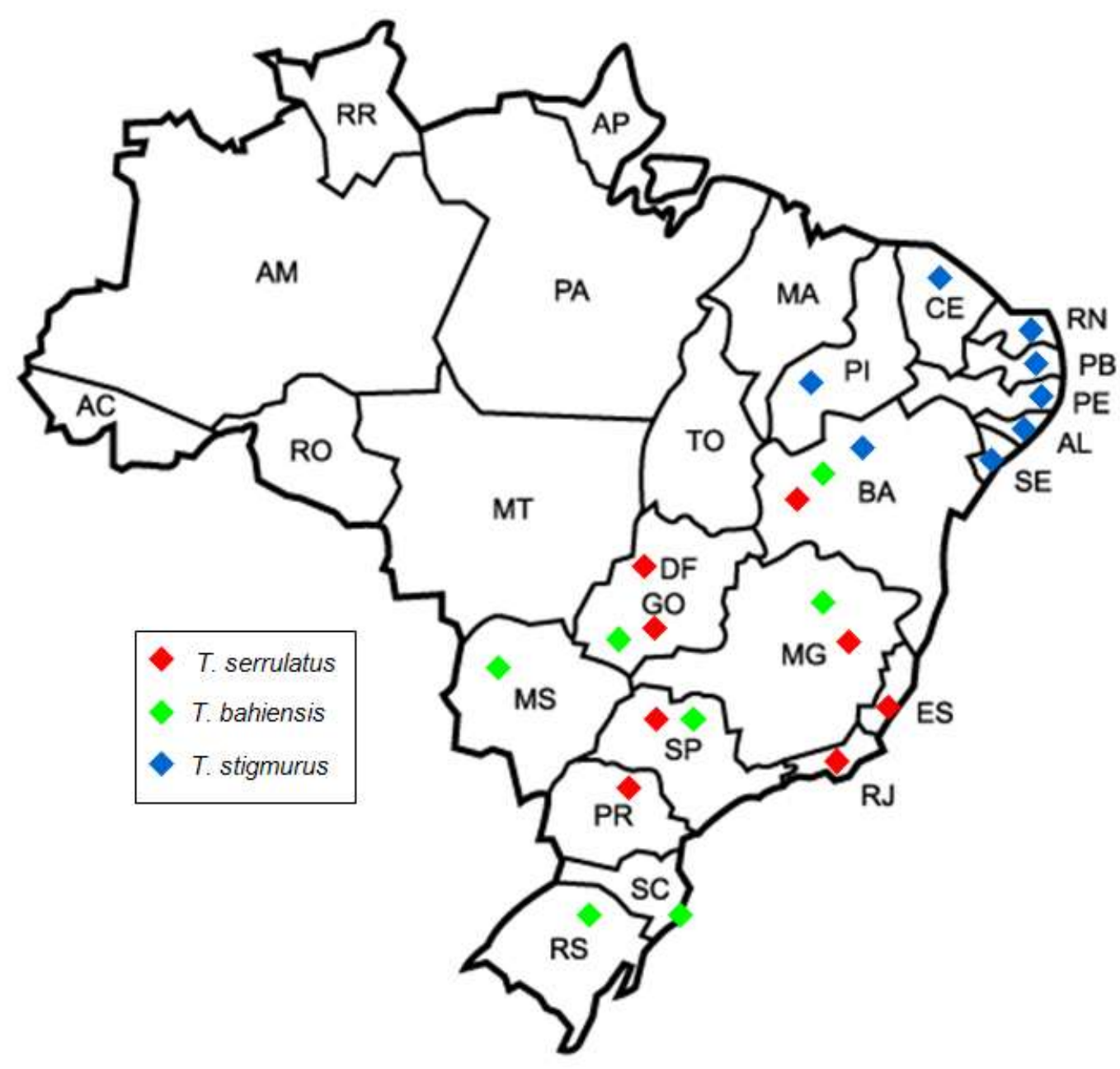

Adaptado de Marcussi et al., (2011). É possível notar que as espécies que mais assolam a Região Sudeste do país são as representadas pelo T. serrulatus e T. bahiensis. A espécie T. stigmurus é responsável pela maioria dos acidentes mais graves na Região Nordeste.

Dados recentes, fornecidos pelo Sistema de Informação de Agravos de Notificação (SINAN), mostram que em 2011 o número de acidentes causados por escorpiões chegaram a 60.020, superando inclusive os acidentes por outros animais peçonhentos como aranhas e serpentes (Figura 4). Dentre estes casos foram registrados 85 óbitos, onde 40 foram de crianças entre zero e 14 anos com $65 \%$ relacionados a crianças menores de 4 anos, apontando letalidade dependente de faixa etária, demonstrando-se como uma preocupação para a saúde pública. 
Figura 4 - Representação do número de acidentes registrados no SINAN em 2011.

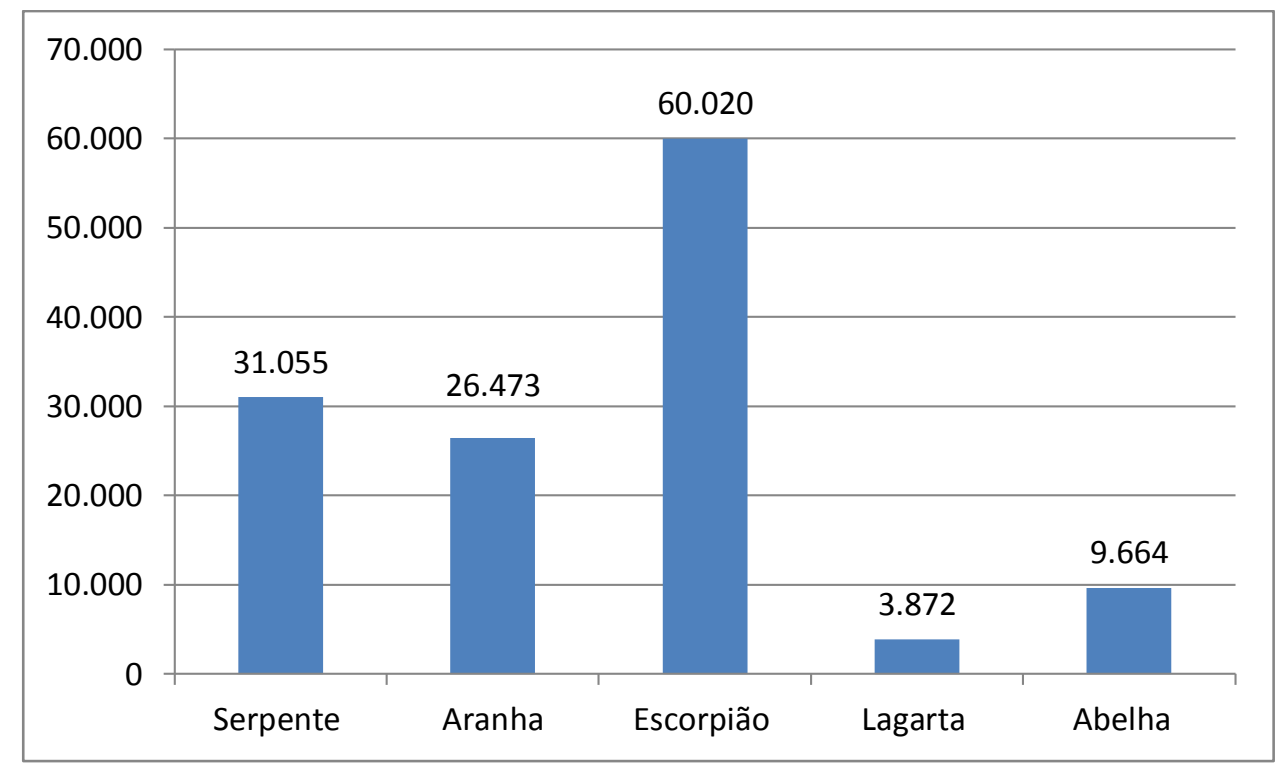

O escorpionismo foi responsável por aproximadamente $45 \%$ dos casos registrados sobre acidentes envolvendo animais peçonhentos no ano de 2011. Este número foi maior que a soma dos acidentes causados por serpentes e aranhas nesse mesmo ano.

Em relação ao quadro clínico dos acidentados, a ação pode ser dividida em local ou sistêmica e a classificação do acidente em leve, moderado ou grave (CUPO et al., 1994).

Em quadros de ação local, os pacientes relatam dor que pode ser discreta ou insuportável, podendo irradiar-se para todo o membro atingido e persistir por várias horas ou dias. O local da picada pode ser identificado com dificuldade podendo se observar edema leve, hiperemia, acompanhado ou não de sudorese ou piloereção local. Em casos mais graves, a dor é mascarada pelas manifestações sistêmicas, aparecendo após melhoras das condições gerais do paciente.

Em quadros de manifestações sistêmicas ocorrem: manifestações gastrintestinais, respiratórias, cardiocirculatórias e neurológicas (CUPO et al., 1994).

Geralmente nos acidentes, a dor local é imediata, seguida das manifestações sistêmicas. Após 2 ou 3 horas é possível a determinação da gravidade do acidente, pois o quadro leve pode ou não evoluir para moderado ou grave (MARCUSSI et al., 2011). A Figura 5 representa a classificação dos casos de escorpionismo registrados em 2011 (SINAN). 
Figura 5 - Classificação dos casos de escorpionismo no Brasil em 2011.

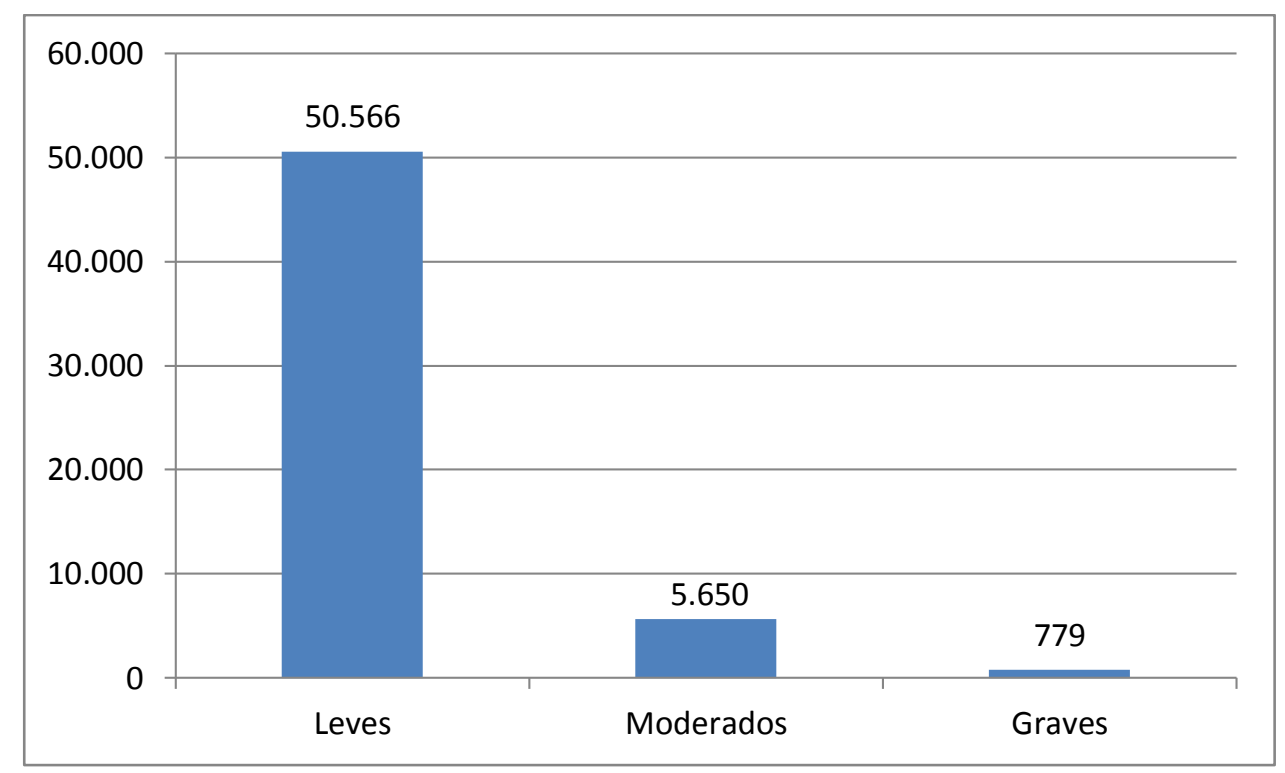

A maior parte das pessoas acidentadas apresenta quadros leves em relação a acidentes relacionados à peçonha de escorpiões no Brasil. Importante notar que a apresentação de quadros mais graves é relativamente rara.

Em relação ao tratamento das vítimas, o combate à dor como medida única é geralmente suficiente para todos os casos leves e casos moderados em adultos. O soro antiescorpiônico ou antiaracnídico deve ser administrado em todos os casos graves e em casos moderados para crianças menores de 7 anos. Todos os casos graves devem ser monitorados quanto à frequência cardíaca, respiratória, pressão arterial, oxigenação, equilíbrio ácidobásico e estado de hidratação. As complicações mais temidas em casos graves estão relacionadas a arritmias cárdicas, choque e edema pulmonar, que devem ser controlados a tempo para não levarem a óbito principalmente crianças acidentadas (FUNASA, 1998). O prognóstico dos casos depende de fatores importantes como o diagnóstico precoce, a idade dos acidentados (menores de 7 anos são mais vulneráveis), o tempo do socorro (acidente $\mathrm{X}$ soroterapia), a espécie e o tamanho do escorpião envolvido e a sensibilidade do paciente a peçonha (MARCUSSI et al., 2011).

Escorpiões são de difícil erradicação por inseticidas e outros agentes. A prevenção de acidentes escorpiônicos é baseada nos hábitos e habitats dos escorpiões, pois a maioria dos acidentes ocorre em locais onde estes animais se escondem, como entulhos, telhas, madeiras, lixo, terrenos baldios, jardins e quintais abandonados, principalmente em zonas rurais. Uma forma de prevenção é a manutenção da limpeza dos possíveis locais onde os escorpiões podem ser encontrados e preservar predadores naturais como sapos, lagartos, lagartixas e galinhas (MARCUSSI et al., 2011). 
Portanto, o estudo dos componentes da peçonha do escorpião é de grande valia para a saúde pública no que se diz respeito ao entendimento dos mecanismos de ação e métodos de intervenção em caso de acidentes, principalmente se tratando da espécie responsável pelos acidentes mais graves que é a $T$. serrulatus.

\subsection{Tityus serrulatus, o escorpião amarelo}

Os escorpiões desta espécie (Figura 6) atingem até $7 \mathrm{~cm}$, e apresentam como característica tronco escuro, patas, pedipalpos e falsas caudas amarelos, sendo a falsa cauda serrilhada no lado dorsal (FUNASA, 1998). É o escorpião mais perigoso da América do Sul. Não são agressivos, mas atacam quando se sentem acuados, sendo esta a causa da maioria dos acidentes (MARCUSSI et al., 2011). A sua reprodução é partenogenética, não necessitando de um macho para obter uma prole, sendo este um dos fatores de sua infestação nos ambientes urbanos (LOURENÇO, 2008).

Figura 6 - Tityus serrulatus

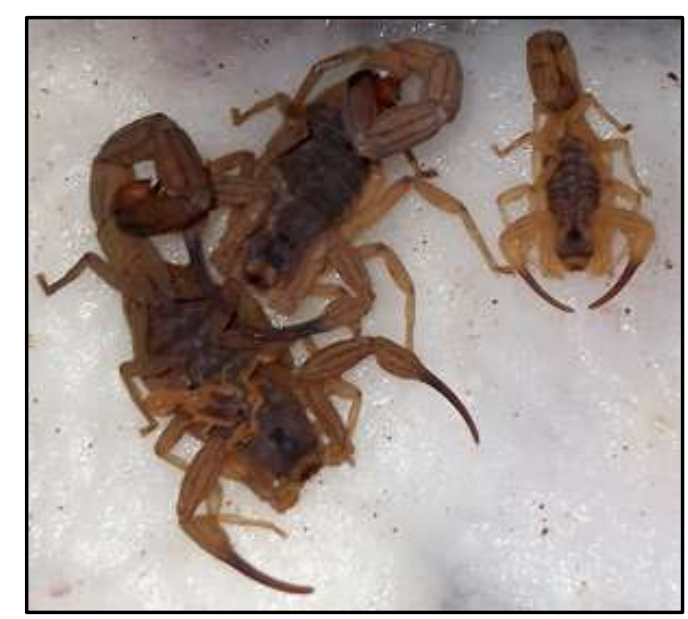

Indivíduos da espécie T. serrulatus. Foto tirada por Bruno Duzzi - Instituto Butantan

A peçonha do T. serrulatus é capaz de exercer uma variedade de efeitos em tecidos excitáveis por causa do seu papel no sistema nervoso periférico onde ele aumenta a liberação de neurotransmissores (FREIRE-MAIA; CAMPOS, 1989).

Alguns dos sintomas apresentados por vítimas de envenenamento por escorpiões são: febre, agitação psicomotora, salivação excessiva, lacrimação, aumento da motilidade gastrintestinal, arritmias cardíaca e respiratória, hipertensão arterial seguida de hipotensão, 
insuficiência cardíaca e choque. A capacidade das toxinas presentes no veneno de agir em canais de sódio e de potássio em terminações nervosas pode explicar, em partes, essas manifestações (FREIRE-MAIA; CAMPOS, 1989). Nos casos de acidentes por Tityus serrulatus, a complicação clínica que mais se destaca é o edema pulmonar agudo, responsável pela maioria dos casos de óbitos, principalmente envolvendo crianças (CUPO et al., 1994). A origem desta patologia é muito complexa e atua, principalmente, através de dois mecanismos: os cardiogênicos e os não cardiogênicos (SILVA et al., 2005). Dentre os fatores cardiogênicos, temos a hipertensão arterial, o aumento do retorno venoso e insuficiência do miocárdio (AMARAL et al., 1993). Os mecanismos não cardiogênicos são consequência da liberação de substâncias vasoativas que podem levar ao aumento da permeabilidade vascular (MATOS et al., 1997). Estudos realizados em ratos em 1996 demonstraram que a peçonha de T. serrulatus tem como órgão alvo o pulmão, onde grandes concentrações de toxinas foram encontradas após 15 e 30 minutos de inoculação do veneno (aproximadamente $160 \mu \mathrm{g}$ de veneno por mg de tecido). Esta concentração superou a encontrada em outros órgãos como baço, coração e fígado (REVELO et al., 1996).

Os principais componentes da peçonha do T. serrulatus estudados até então são:

Ts1 - Pertence à classe das $\beta$-neurotoxinas, interagindo com o sítio receptor 4 de canais para $\mathrm{Na}^{+}$(JONAS et al., 1986). Induz liberação de catecolaminas e aumento da pressão arterial (VASCONCELOS et al., 2005). Leva a liberação de glutamato de sinaptosomas, dopamina de fatias de córtex e oxido nítrico de preparação de músculo retrator peniano (BOMFIM et al., 2005). Aumento dos níveis plasmáticos de aminotransferases, amilase, creatina quinase, lactato desidrogenase, congestão hepática, hemorragia pulmonar e renal, hipertrofia e degradação de áreas cardíacas, hiperglicemia e níveis altos de ácidos graxos no sangue de animais (CORRÊA et al., 1997).

Ts2 - Uma $\beta$-neurotoxina, dentre suas ações comprovadas está à indução do prolongamento do potencial de ação de fibras mielinizadas do nervo de coelhos, efeito clássico de $\alpha$-toxinas (SAMPAIO et al., 1991). Experimentos com injeções no hipocampo demonstraram aumento na concentração de glutamato e aumento da concentração de $\mathrm{Ca}^{2+}$ intracelular (SANDOVAL; LEBRUN, 2003b).

Ts3 - Possui 62 resíduos de aminoácidos capaz de inibir a inativação de canais de $\mathrm{Na}^{+}$ em neuroblastos (KIRSCH et al., 1989). Leva a liberação de vários mediadores como catecolaminas e acetilcolina (CLEMENTE et al., 2002).

Ts5 - $\alpha$-toxina onde os prováveis mediadores responsáveis pela hipertensão são as catecolaminas, conduzidas pelas alterações nos canais para $\mathrm{Na}^{+}$. 
Ts4 - Foi considerada não tóxica para camundongos, pois não foi capaz de apresentar os quadros característicos da toxicidade produzida por outras toxinas. Porém, causa reações alérgicas, lacrimejamento e liberação dose-dependente de neurotransmissores (GABA e Glu) de sinaptossomos (SAMPAIO et al., 1996).

Ts6 - Interferem em canais para $\mathrm{K}^{+}$(NOVELLO et al., 1999).

Ts7 - Foi capaz de bloquear, com elevada afinidade, canais para $\mathrm{K}^{+}$em células de fibroblastos transformadas para Kv1.2 (WERKMAN et al., 1993).

Ts8 - Capaz de bloquear seletivamente canais para $\mathrm{K}^{+}$não-inativantes dependentes de voltagem de sinaptosomas de cérebro de ratos (ROGOWSKI et al., 1994).

Ts9 - Potente ligante de canais para $\mathrm{K}^{+}$ativados por cálcio de baixa condutância sensível a apamina (LEGROS et al., 1996).

Ts15 - Bloqueia seletivamente os subcanais para $\mathrm{K}^{+} \mathrm{Kv} 1.2$ e Kv 1.3 (MARCUSSI et al., 2011).

Hialuronidases - Enzimas capazes de degradarem o ácido hialurônico encontrado na matriz extracelular dos tecidos conjuntivos frouxos. Facilita a difusão de toxinas através dos tecidos, potencializando a toxicidade de outros componentes da peçonha ( MARCUSSI et al., 2011; POSSANI et al., 1977).

Proteases - Podem estar relacionadas com o processamento pós-traducional das toxinas (MARTIN-EAUCLAIRE et al., 1994). Algumas proteases são capazes de ativar o sistema complemento, podendo desempenhar um papel relevante no processo inflamatório que ocorre em consequência ao envenenamento (MARCUSSI et al., 2011).

Peptídeos - São encontrados muitos peptídeos nas frações de baixa massa molecular do veneno do T. serrulatus. Estudos realizados pelo grupo de Verano-Braga e colaboradores (2013) demonstraram a presença de 317 peptídeos encontrados nas frações menores que 10.000 Da, onde a maioria desses peptídeos possuía um tamanho menor que 3.500 Da. Os autores indicam que $80 \%$ dos peptídeos sequenciados foram apresentados como fragmentos de toxinas já existentes, provenientes da ação proteolítica do próprio veneno, como fragmentos derivados da Hipotensina-I, peptídeos Pape (fragmentos de sequência tetrapeptidica Pro-Ala-Pro-Glu de repetição em tandem), TsTXK-beta, propeptídeo Beta-Ktxlike, BPPs, Ts6, Ts5, Ts2, Tb1, hormônios diuréticos de classe II, hipotensina II, dentre outros. (VERANO-BRAGA et al., 2013).

Como exemplos de peptídeos com atividade biológica, isolados a partir do escorpião T. serrulatus, temos a Ts10, um peptídeo que apresenta 13 resíduos de aminoácidos que potencializam a ação da bradicinina sem ter a característica de um típico peptídeo 
potencializador de bradicinina (BPP) (FERREIRA et al., 1993). A Ts11, 12 e 13 que são cadeias com 29 aminoácidos, semelhantes a toxinas que atuam em canais de $\mathrm{K}^{+}$. Sua funções biológicas ainda não estão esclarecidas (PIMENTA et al., 2003). A Ts14, que são peptídeos lineares randômicos, similares a BPPs que potencializam a bradicinina, mas também não inibem a ECA (VERANO-BRAGA et al., 2008). A Ts16, que possuí 29 resíduos de aminoácidos, apresentando homologia com as toxinas que atuam em canais de $\mathrm{K}^{+}$, porém estudos são necessários para confirmarem esta possível ação (MARCUSSI et al., 2011). Além destes peptídeos citados, também são encontrados peptídeos com propriedades antimicrobianas (AMPs), como o TsAP-1 (que também apresentou ação anticâncer) e TsAP-2 (que também apresentou propriedades hemolítica e anticâncer), dentre outros (ALMAAYTAH; ALBALAS, 2012).

Além destes peptídeos já identificados e isolados, um estudo recente de transcriptoma da glândula produtora da peçonha do T. serrulatus mostrou que os compostos peptídicos codificados e que poderiam estar presentes na peçonha se apresentaram como peptídeos Pape (23\%), peptídeos aniônicos (3\%), peptídeos antimicrobianos (17\%) além de outros, representando 9\% das toxinas totais (ALVARENGA et al., 2012). Estas informações demonstram que muitos estudos deverão ser realizados para a identificação de novos peptídeos que apresentem alguma atividade biológica, pois peptídeos são moléculas vastamente encontradas na peçonha do escorpião amarelo.

\subsection{Enzimas proteolíticas}

As enzimas proteolíticas desempenham um papel importante no ciclo de vida dos organismos vivos. Em mamíferos essas enzimas participam do processamento e da organização molecular das cadeias polipeptídicas nascentes, dos processamentos de precursores de hormônios proteicos, receptores e fatores de crescimento, ativação de enzimas envolvidas em processo de cascata proteolítica, como na coagulação sanguínea, na fibrinólise, nas reações do sistema complemento e na geração de peptídeos bioativos. Participam também de processos de morte celular programada, migração e adesão celular, invasão de microorganismos, entre outros (NEURATH, 1999). Em virtude da ampla diversidade de enzimas conhecidas, as peptidases foram agrupadas com base no mecanismo catalítico e em suas estruturas primárias e terciárias. Existem até o momento cinco grandes classes de enzimas proteolíticas: serinoprotease, cisteínoprotease, metaloprotease, aspartilprotease e 
treoninaprotease. A seguir, serão apresentados maiores detalhes das metalopeptidases, pois esta classe de enzimas proteolíticas será alvo do nosso estudo (RAWLINGS et al., 2004).

\subsubsection{Metalopeptidases}

As metalopeptidases são enzimas que geralmente apresentam a sequência consenso (H-E-X-X-H) em sua sequência primária de aminoácidos, onde a letra $X$ indica qualquer resíduo de aminoácido. Nas metalopeptidases um cátion metal divalente, geralmente zinco, mas algumas vezes cobalto ou manganês, ativa uma molécula de água, que faz o ataque à ligação peptídica susceptível à hidrólise. Os resíduos ligantes de metais conhecidos são os aminoácidos His, Glu, Asp ou Lys. Além destes, pelo menos outro resíduo é necessário para catálise, que é geralmente o resíduo Glu. As metalopeptidases estão envolvidas nas mais variadas atividades como: no desenvolvimento embrionário, na formação óssea, reprodução, artrite e câncer (RAWLINGS et al., 2004). Por conta da importância deste grupo de enzimas, estudaremos em nosso trabalho a interação de oligopeptídeos escorpiônicos em relação à timet oligopeptidase (EP 24.15) e a neurolisina (EP 24.16). Foram inclusas em nossos estudos também as enzimas neprilisina (EP 24.11) e enzima conversora de angiotensina (ECA).

1.5.2 Timet oligopeptidase (EP 24.15), neurolisina (EP 24.16), neprilisina (EP 24.11), enzima conversora de angiotensina (ECA)

As endopeptidases EP 24.15 (E.C. 3.4.24.15; timet oligopeptidase) e EP 24.16 (E.C. 3.4.24.16; neurolisina) são metaloendopeptidases que exibem o motivo característico de ligação com zinco HEXXH, pertencentes à família M3 de metalopeptidases (BARRETT et al., 1995; RAWLINGS et al., 2004). A EP 24.15 possui 687 resíduos de aminoácidos com massa molecular em torno de 78 kDa ( MCKIE et al., 1993; PIEROTTI et al., 1991), enquanto a EP 24.16 possui 704 resíduos de aminoácidos com massa molecular também em torno de $78 \mathrm{kDa}$ ( BROWN et al., 2001; DAUCH et al., 1995). Essas enzimas possuem uma especificidade restrita a oligopeptídeos de 5 a 17 resíduos de aminoácidos (OLIVEIRA et al., 2001). O isolamento e sequenciamento dos cDNAs codificantes para a EP 24.15 e EP 24.16 de cérebro de ratos mostraram homologia de aproximadamente 60\% (DAUCH et al., 1995).

As funções peptidásicas da EP 24.15 e da EP 24.16 vêm sendo implicadas no metabolismo de uma série de neuropeptídeos e como consequência, envolvidas em vários processos fisiológicos. A EP 24.15 tem sido relacionada com a percepção de dor ( GOMEZ et 
al., 2011; KEST et al., 1992; SHRIMPTON et al., 2002), a homeostase cardiovascular e renal (AYALA, 1990; CARDOZO; ORLOWSKI, 1993; ORLOWSKI et al., 1983; TELFORD et al., 1995) a reprodução (LEW et al., 1995; PIEROTTI et al., 1991; WU et al., 1997) apresentação de antígenos via MHC-I ( KIM et al., 2003; PORTARO et al., 1999; SILVA et al., 1999; YORK et al., 2003) e degradação e geração de peptídeos intracelulares biologicamente ativos ( BERTI et al., 2009; CUNHA et al., 2008). Sua distribuição em mamíferos é ubíqua, porém relatou-se a presença de sua atividade principalmente no cérebro, hipófise e testículos e em menor intensidade nos rins, coração, fígado, baço e pulmões (CHU; ORLOWSKI, 1985; LINARDI et al., 2004). Esta oligopeptidase cliva preferencialmente sítios no C-terminal de aminoácidos hidrofóbicos com uma preferência adicional a resíduos aromáticos ou básicos na região P2 (ORLOWSKI et al., 1983). Embora as funções intracelulares da EP 24.16 não tenham sido exploradas como as da EP 24.15, essas enzimas possuem conformação tridimensional e substratos específicos similares (Figura 7) ( RAY et al., 2002, 2004; RIOLI et al., 1998), sugerindo que as funções intracelulares sejam semelhantes. Como substratos naturais em comum apresentam a dinorfina A1-8, GnRH, angiotensina I, somatostatina e neurotensina, sendo esta ultima clivada em diferentes sítios, demonstrando uma das características responsáveis pela diferenciação entre elas (SHRIMPTON et al., 2002). Estudos destas enzimas desenvolvidos em cérebros de ratos apontaram que a EP 24.16, em sua maioria, se encontra na região extracelular já a EP 24.15 se encontra principalmente na região nuclear (MASSARELLI et al., 1999). 
Figura 7 - Estrutura da timet oligopeptidase (EP 24.15) e neurolisina (EP 24.16)
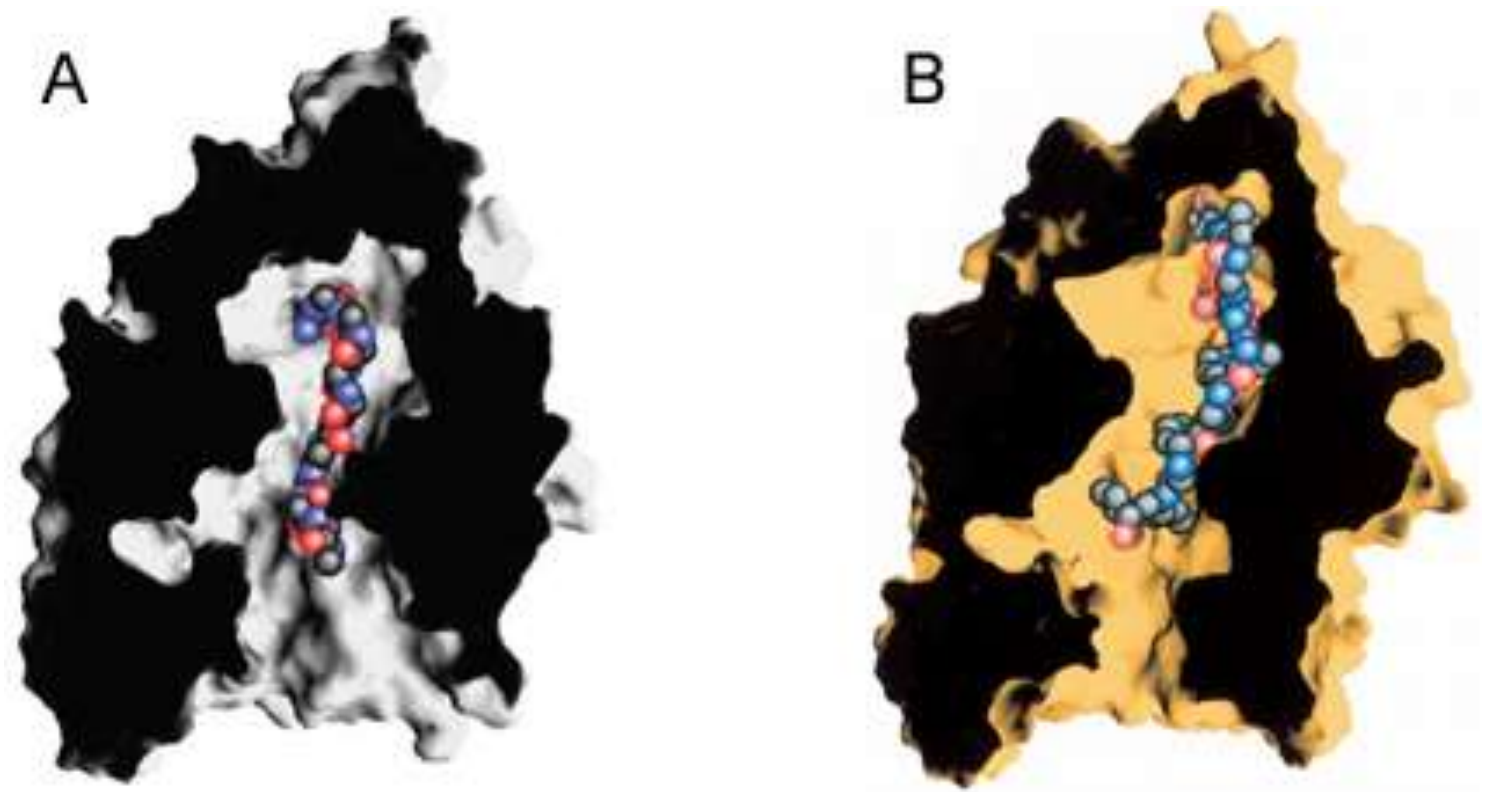

Modelo da superfície molecular durante a ligação com o substrato peptídico da timet oligopeptidase (A) e da neurolisina (B). Em ambas as estruturas é possível notar um profundo canal relacionado à localização do sítio catalítico e que explica a ação destas enzimas sobre oligopeptídeos. Figuras adaptadas de Ray et al., (2004) e Brown et al., (2001) respectivamente.

Além de distintos pontos de clivagem em relação ao substrato neurolisina, outra maneira de diferenciação da EP 24.16 de enzimas de sua família é o fato dela não ser inibida pelos principais inibidores como Captopril, Tiorfan ou inibidores de serino proteases (SHRIMPTON et al., 2002).

As evidências experimentais acumuladas ao longo dos últimos anos corroboram dados da literatura de que a maior parte de EP 24.15 está presente no meio celular interno (FONTENELE-NETO et al., 2001). Desta forma, além da participação no metabolismo de neuropeptídeos, procuramos investigar a função da EP 24.15 no metabolismo intracelular de peptídeos. Para tal, foram geradas mutações pontuais que levaram à inativação catalítica das EP 24.15 e EP 24.16. O uso dessas formas cataliticamente inativas permitiu o isolamento e identificação de vários peptídeos anteriormente desconhecidos a partir de tecidos de mamíferos e venenos animais, originando em 2003 a identificação da hemopressina, um potente agente hipotensor, oriunda do cérebro de camundongos e em 2008 o BPP-AP, uma molécula potencializadora de bradicinina oriunda do veneno da jararacuçu (RIOLI et al., 2003, 2008). Assim, acreditamos que a utilização das oligopeptidases EP24.15 e/ou EP24.16 inativas para a busca de novos ligantes peptídicos biologicamente ativos presentes no veneno do T. serrulatus será bastante produtiva, tanto para um melhor entendimento deste veneno e 
seus mecanismos de ações, quanto das própias oligopeptidases, uma vez que as funções in vivo das mesmas não estão totalmente esclarecidas.

A EP 24.11, também conhecida como neprilisina ou encefalinase (E.C. 3.4.24.11), é uma proteína integral de membrana (tipo II), presente como uma ectoenzima, visto que seu sítio ativo está voltado para o espaço extracelular (BARRETT et al., 1998). Esta enzima apresenta aproximadamente 27 resíduos de aminoácidos da porção N-terminal no citoplasma, seguida de um domínio transmembrânico composto por 23 resíduos e o restante da molécula localizada na região extracelular (LI; HERSH, 1995). A NEP é abundante no intestino, rim e placenta, e é também encontrada em células reticulares do sistema imune. Ela está presente, em menor concentração, em outros tecidos e tipos celulares, incluindo o cérebro, onde se localiza nas células neuronais (BARRETT et al., 1998). Esta enzima normalmente atua como uma endopeptidase e hidrolisa peptídeos contendo até 40 resíduos de aminoácidos, contudo, a eficiência de hidrólise diminui com o aumento do tamanho do peptídeo. Os principais substratos in vivo da NEP são os hormônios natriuréticos (ANP, BNP e CNP), as endotelinas, a bradicinina, a substância P (BARRETT et al., 1998), a encefalina (ROQUES et al., 1993) e a proteína beta amiloide, uma das responsáveis pela doença de Alzheimer (IWATA et al., 2001). Tendo esta importância, a busca por inibidores desta enzima vem sendo aplicada no desenvolvimento de moléculas relacionadas ao tratamento da dor e regulação da pressão arterial (ROQUES et al., 1993).

A enzima conversora de angiotensina, ECA (EC 3.4.25.1), foi isolada inicialmente em 1956 (SKEGGS et al., 1956). É uma proteína de 180 kDa com dois domínios homólogos, onde cada um tem um sítio ativo com o motivo H-E-X-X-H para a ligação de um íon metálico $\mathrm{Zn}^{2+}$.

Com a resolução da estrutura tridimensional, foi demonstrada grande semelhança estrutural entre seus sítios ativos e das enzimas EP 24.15 e EP 24.16, desta maneira, possíveis substratos e/ou inibidores destas enzimas podem interagir com a ECA (NATESH et al., 2004).

Descrita inicialmente como uma carboxipeptidase, ela apresentou atividade endopeptidásica em alguns substratos. Por hidrolisar dois importantes substratos fisiológicos envolvidos na regulação da pressão arterial, a procura de inibidores sempre foi um alvo de estudos para o tratamento da hipertensão.

No final da década de 70, potentes inibidores desta enzima foram descritos e até hoje utilizados na terapêutica como o Captopril (ONDETTI et al., 1977) e o Enalapril (PATCHETT et al., 1980). 
É uma ectoenzima ancorada à membrana plasmática e é encontrada em diferentes formas (somática, germinal e solúvel) em células endoteliais, epiteliais, neuroepiteliais e células germinativas (DAS et al., 1977).

Esta enzima tem um importante papel na homeostase circulatória, pois é responsável pela clivagem da angiotensina I, produzindo um potente vasoconstritor, a angiotensina II (SKEGGS et al., 1956) e inativa o vasodilatador bradicinina (BK) (YANG et al., 1970). Ela também hidrolisa um peptídeo inativo, a angiotensina (1-9) um metabólito vasodilatador, a angiotensina (1-7) (PATCHETT et al., 1980).

Em humanos a ECA se encontra distribuída em inúmeros tecidos como células epiteliais (como exemplo rins, placenta, intestino), células neuroepiteliais e o trato genital masculino (SKIDGEL; ERDÖS, 1987). Por conta de sua ampla distribuição, além de atuar em substratos como a angiotensina I e bradicinina, ela atua sobre encefalinas (SKIDGEL; ERDÖS, 1987), substância P (SKIDGEL et al., 1984), hormônio luteinizante (SKIDGEL; ERDÖS, 1985), angiotensina 1-7 e a neurotensina (SKIDGEL et al., 1984).

Deste modo, selecionamos estas enzimas para nossos estudos, visando à relação das mesmas com os quadros graves apresentados por alguns acidentados e com o poder do potencial biotecnológico de moléculas capazes de exercerem modulações. 


\section{OBJETIVOS}

\subsection{Objetivo geral}

Identificar e caracterizar peptídeos de baixa massa molecular na peçonha do escorpião T. serrulatus que interajam com oligopeptidases (EP 24.15 e EP 24.16) e que possam ser importantes na fisiopatologia do envenenamento ou usados como ferramentas biotecnológicas.

\subsection{Objetivo específico}

- Isolar e sequenciar oligopeptídeos da peçonha do T. serrulatus;

- Sintetizar as sequências oligopeptídicas selecionadas pelo sequenciamento;

- Testá-las in vitro em relação à interação com as oligopeptidases EP 24.15 e EP 24.16, determinando conforme o caso, a constante de inibição (Ki) e mecanismo de ação inibitória;

- Analisar as interações em relação a outras peptidases de importância fisiopatológica (neprilisina e ECA);

- Investigar os efeitos desses peptídeos em ensaios biológicos relacionados a sensibilidade nociceptiva, rolamento de leucócitos e reação vascular (vasoconstrição/vasodilatação) da microcirculação. 


\section{MATERIAL E MÉTODOS}

\subsection{Peçonha}

A peçonha bruta, na sua forma liofilizada, foi fornecida pela Seção de Venenos do Instituto Butantan. O fornecimento desta peçonha seguiu todas as normas impostas para solicitação deste material. Cabe aqui ressaltar, que a licença para o uso deste material foi concedia junto ao CGEN. (Autorização de acesso e remessa ao patrimônio genético para o Laboratório Especial de Toxinologia Aplicada do Instituto Butantan, número 01/2008; processo 02001.001171/2008).

\subsection{Expressão das enzimas timet oligopeptidase (EP 24.15) e neurolisina (EP 24.16) recombinantes selvagens e mutantes cataliticamente inativas E474A e E475A respectivamente}

Foram empregados clones já caracterizados e disponíveis em nosso laboratório (RIOLI et al., 1998, 2003). Para a expressão das enzimas, colônias de Escherichia coli DH5- $\alpha$ transformadas com o vetor pGEX4T-2 contendo o cDNA da EP 24.15 e outras com o da EP 24.16 selvagens e mutantes, que apresentavam mutações sítio-dirigidas (EP 24.15 (E 474 A) e EP 24.16 (E 475 A)), que possibilitam a ligação de peptídeos que sejam substratos e/ou inibidores ao sítio ativo "desativado" pela mutação sem serem degradados pela enzima, foram repicadas em meio LB-ágar contendo ampicilina $(50 \mu \mathrm{g} / \mathrm{mL})$. Uma colônia isolada foi escolhida aleatoriamente, e transferida para um tubo de $50 \mathrm{~mL}$, contendo $5 \mathrm{~mL}$ de meio $\mathrm{LB}$ e ampicilina $(100 \mu \mathrm{g} / \mathrm{mL})$. Após crescimento a $37^{\circ} \mathrm{C}$ sob agitação $(250 \mathrm{rpm})$ durante 8 horas, a cultura foi transferida para $50 \mathrm{~mL}$ de meio LB contendo ampicilina $(100 \mu \mathrm{g} / \mathrm{mL})$. Após incubação a $37{ }^{\circ} \mathrm{C}$ sob agitação $(250 \mathrm{rpm})$ durante 16 horas, a cultura bacteriana foi transferida para 4 litros de meio LB, crescendo até um valor de absorbância a $600 \mathrm{~nm}$ entre 0,6 e 0,7 . A temperatura foi reduzida para $30{ }^{\circ} \mathrm{C}$, e adicionado $0,5 \mathrm{mM}$ de isopropil- $\beta-\mathrm{D}-1-$ tiogalactopiranosídeo (IPTG) como indutor da expressão das proteínas selvagens e mutantes. Após 4 horas de indução, as culturas foram submetidas à centrifugação (5000 x G durante 20 minutos) para sedimentação das bactérias e descarte do sobrenadante. Os pellets foram ressuspendidos em $150 \mathrm{~mL}$ de tampão PBS 0,15 M, pH 7,4, incubados durante 20 minutos na presença de lisozima $(10 \mathrm{mg} / \mathrm{mL})$ a temperatura ambiente, e então submetidos a 3 ciclos de sonicação (Tomy Ultrasonic Disruptor UD-201) de 40 segundos a $40 \mathrm{hz}$ em gelo, com intervalo de 1 minuto entre eles. O homogenato obtido foi centrifugado a 5000 x G por 30 
minutos a $4{ }^{\circ} \mathrm{C}$, sendo o sobrenadante removido cuidadosamente e incubado durante 30 minutos em temperatura ambiente, sob rotação horizontal branda, com a resina GlutationaSepharose $^{\circledR}$ (GE Healthcare, Little Chalfont, Buckinghamshire, Reino Unido) previamente equilibrada em tampão PBS $0,15 \mathrm{M}$ pH 7,4. A resina foi removida do sobrenadante por centrifugação a 500 x G, por 5 minutos, e transferida para uma coluna de cromatografia. Na coluna, a resina foi lavada exaustivamente com tampão Wash (50 mM Tris pH 7,4 contendo $150 \mathrm{mM}$ de $\mathrm{NaCl}$ ) e em seguida com tampão Wash + cálcio (50 mM Tris pH 7,4, contendo 50 $\mathrm{mM} \mathrm{NaCl}$ e 2,5 mM de $\mathrm{CaCl}_{2}$ ). A seguir foram adicionados $100 \mathrm{U}$ de trombina (GE Healthcare) por mL de resina, a qual foi incubada por 16 horas, a temperatura ambiente em rotação horizontal. As proteínas recombinantes livres foram eluídas da coluna em tampão 50

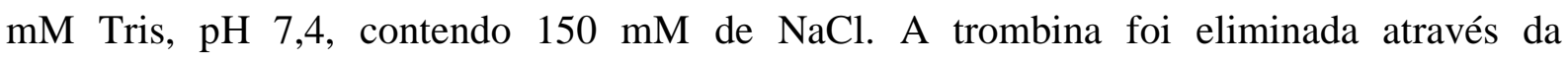
concentração das amostras, por ultrafiltração em membranas de exclusão molecular Centrifugal Filter Unit 50.000 NMCO Amicon ${ }^{\circledR}$ (Millipore Corporation, Billerica, MA, EUA). Para a observação de pureza, as amostras foram submetidas à análise por SDS-Page em gel de poliacrilamida (8\%) corado com Coomassie-Blue e posteriormente descorado com solução descorante (50\% de metanol e 10\% de ácido acético). Em seguida, as proteínas foram quantificadas pelo método de Bradford (1976).

Para a caracterização catalítica e confirmação da mutação, foram realizados testes cinéticos para a determinação da atividade enzimática das enzimas recombinantes selvagens e mutantes. Os testes foram realizados em duplicata em um fluorímetro Victor $3^{\circledR}$ (PerkinElmer, Walthan, MA, EUA), onde 7,5 ng de proteína selvagem recombinante foram adicionadas a $10 \mu \mathrm{M}$ de substrato fluorescente QFS (7-MCA-4-ac-PLGPdLys-(2,4dinitrophenyl) (SHRIMPTON et al., 1997), e tampão fosfato $\mathrm{pH} 7,4$ contendo $20 \mathrm{mM}$ de $\mathrm{NaCl}, \mathrm{pH}$ 7,4 e $1 \mathrm{mM}$ de $\beta$-mercaptoetanol (nos experimentos com a EP 24.15). As análises foram monitoradas nos comprimentos de onda a $420 \mathrm{~nm}$ de emissão e $320 \mathrm{~nm}$ de excitação conforme descrito por Araújo et al. (1999). A atividade das oligopeptidases selvagens também foi caracterizada com uso de $30 \mu \mathrm{M}$ de inibidor específico destas enzimas, a dinorfina A 1-13 (Sigma-Aldrich). Os gráficos foram plotados no programa Grafit 5 e em seguida comparados e analisados. $\mathrm{O}$ mesmo procedimento, exceto pela adição do inibidor específico, foi realizado empregando as enzimas cataliticamente inativas. 


\subsection{Fracionamento da peçonha do Tityus serrulatus para a obtenção da fração de baixa massa molecular}

Dez miligramas da peçonha total de $T$. serrulatus foram adicionados em 1,0 mL de tampão (10 mM de acetato de amônio, $\mathrm{pH} 4,0)$, para inativação de proteases, e em seguida fracionado em membrana de exclusão molecular de $3 \mathrm{kDa}$ Amicon ${ }^{\circledR}$ Ultra - 0,5 mL 3K (Millipore Corporation, Billerica, MA, EUA) e liofilizado. O material não retido pela membrana (fração contendo moléculas $\leq 3 \mathrm{kDa}$ ) foi aplicado em pré-colunas de C18 Waters (Waters Corporation, Milford, MA, EUA), lavado com água Milli-Q ${ }^{\circledR}$ (Millipore Corporation, Billerica, MA, EUA), e eluído em metanol 100\%. Após evaporação do solvente em sistema Speed-Vac, as amostras foram estocadas a $-20^{\circ} \mathrm{C}$ (RIOLI et al., 2003).

Para novos procedimentos, as mesmas técnicas foram empregadas com alteração na quantidade inicial de peçonha utilizada (40 mg ao invés de $10 \mathrm{mg}$ ).

\subsection{Quantificação do pool peptídico de baixa massa molecular da peçonha do $T$. serrulatus através do emprego da fluorescamina}

O método da fluorescamina (SARIC et al., 2004), consiste na aplicação de um marcador de aminas primárias dos resíduos de lisina e no $\mathrm{N}$-terminal dos peptídeos que emite fluorescência a $370 \mathrm{~nm}$ (excitação) e $480 \mathrm{~nm}$ (emissão).

Uma placa branca opaca de 96 poços Corning (Corning Incorporated, Corning, NY, USA) foi utilizada e em cada poço adicionado $2,5 \mu \mathrm{L}$ de amostra, $25 \mu \mathrm{L}$ de tampão fosfato 0,2 M (pH 6,8) e 12,5 $\mu \mathrm{L}$ de solução de fluorescamina $(0,3 \mathrm{mg} / \mathrm{mL})$ diluída em acetona. $\mathrm{O}$ padrão usado para a construção da curva foi o peptídeo 5A (LTLRTKL). A placa foi incubada sob agitação por 1 minuto e logo após, acrescentados $110 \mu \mathrm{L}$ de água Milli- ${ }^{\circledR}$. A leitura da fluorescência foi realizada em um espectrofluorímetro SPECTRAmax ${ }^{\circledR}$ (Molecular Devices Corporation, Sunnyvale, CA, EUA) e os dados processados no programa SoftMax (SoftMax Pro 5.2).

3.5 Isolamento dos possíveis substratos e/ou inibidores peptídicos das enzimas timet oligopeptidase (EP 24.15) e neurolisina (EP 24.16) cataliticamente inativas a partir da fração de baixa massa molecular

De uma maneira geral esta metodologia desenvolvida por Rioli e colaboradores (2003) está esquematizada abaixo (Figura 8), e consiste na incubação das enzimas cataliticamente inativas, com uma fração peptídica bruta obtida a partir de um homogenato de tecido de 
origem animal ou toxinas animais, desde que contenha peptídeos (como o pool de baixa massa molecular da peçonha da Tityus serrulatus, descrito acima). A seguir, uma vez que os peptídeos se associam as enzimas inativadas por mutação sítio-dirigida sem serem degradados, é efetuado um passo de gel filtração para a separação dos peptídeos complexados às enzimas. Para que a diluição do meio de incubação não afete as constantes de dissociação, esse passo de cromatografia de exclusão molecular é realizado com a resina seca ("gel filtração a seco"), onde moléculas menores ficam retidas na resina e moléculas maiores (no caso enzima + peptídeo) passam após centrifugação, onde a diminuissão do volume do tampão possibilita que esta interação de dissociação seja preservada. No eluato final teremos a presença de diversos peptídeos, que terão suas sequências identificadas por espectrometria de massas, que serão analisadas quanto à originalidade utilizando ferramentas de bioinformática. Uma vez identificadas essas sequências peptídicas, as mesmas podem ser sintetizadas e facilmente testadas quanto à interação com peptidases específicas por meio de ensaios cinéticos de competição utilizando substratos fluorogênicos (RIOLI et al., 2003).

Figura 8 - Esquema da captura de peptídeos utilizando enzimas cataliticamente inativas por mutação sítio dirigida

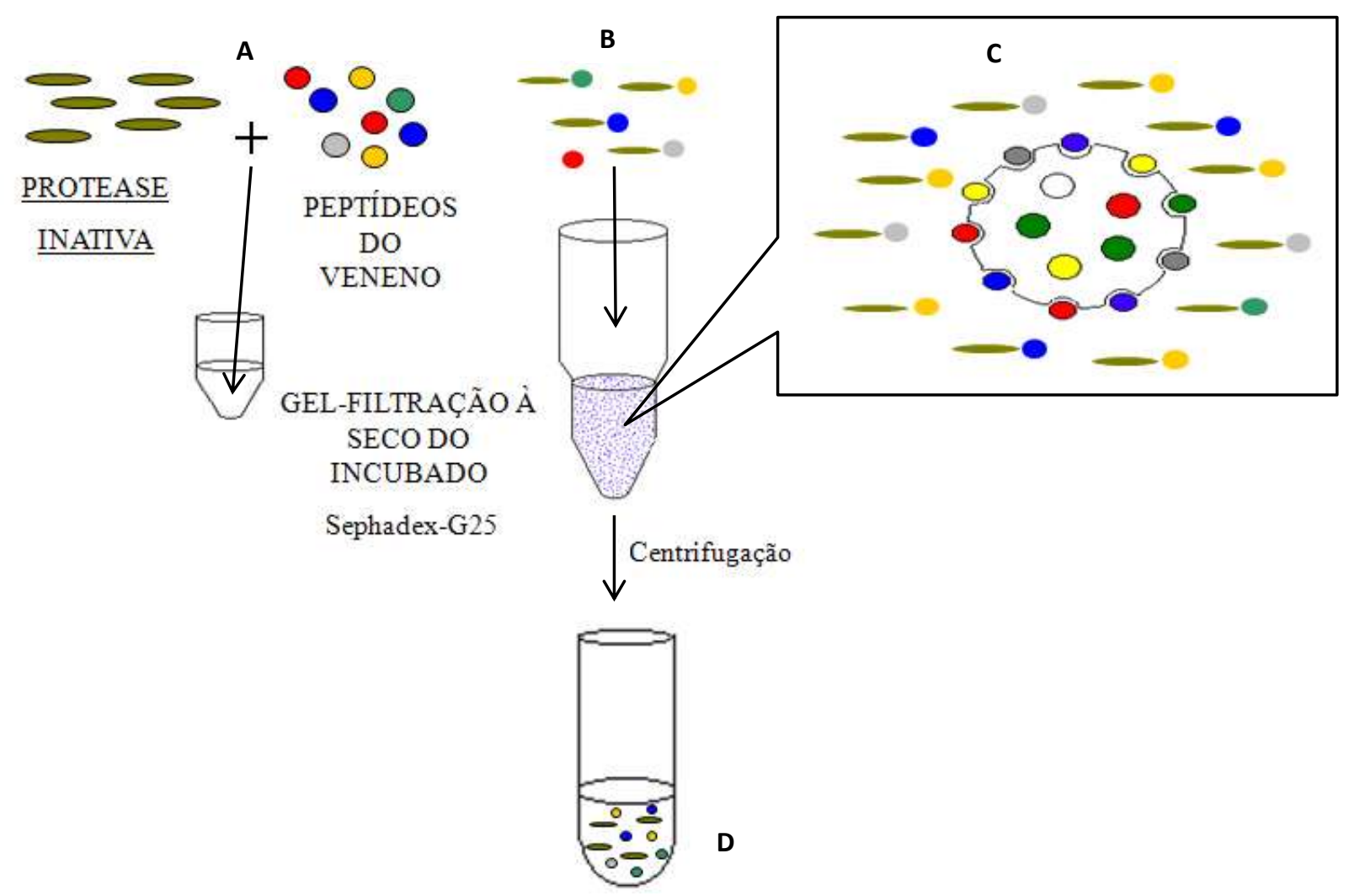

Esquema da metodologia desenvolvida por Rioli et al. (2003) para identificação de peptídeos. Inicialmente é feita a incubação das enzimas cataliticamente inativas com o pool peptídico de interesse (A). Após a associação dos peptídeos às enzimas inativadas (B), é efetuada uma "gel filtração a seco" para a separação dos peptídeos 
complexados às enzimas $(\mathrm{C})$. No eluato final, tem-se a presença de diversos peptídeos que foram capturados e que podem ter suas sequências identificadas por espectrometria de massas (D).

Nos experimentos aqui descritos, as enzimas cataliticamente inativas EP 24.15 e EP

24.16 foram incubadas durante uma hora a temperatura ambiente, com $30 \mu \mathrm{L}$ do pool peptídico originado a partir de $10 \mathrm{mg}$ da peçonha liofilizada em seus respectivos tampões a um volume final de $100 \mu \mathrm{L}$. O controle, relacionado ao sistema acima sem a presença das enzimas inativas também foi realizado. Em seguida, essa mistura foi filtrada em coluna Sephadex ${ }^{\circledR}$ G-25 (Sigma-Aldrich Corporation, Steinheimeim, Alemanha) na proporção de $1 \mathrm{~g}$ de resina para cada $5 \mathrm{~mL}$ de tampão TBS (25 mM Tris $\mathrm{HCl}, 125 \mathrm{mM} \mathrm{NaCl}$ e pH 7,4). As mesmas foram vagarosamente preenchidas com tampão TBS, contendo $0,1 \%$ de albumina do soro bovino. No caso da EP 24.15 o mesmo tampão foi utilizado com a adição apenas de betamercaptoetanol $(5,5 \mu \mathrm{g} / \mu \mathrm{L})$ para evitar a formação de dímeros (SHRIMPTON et al., 1997).

Ao término da incubação das enzimas inativas, as colunas contendo os tampões foram centrifugadas (1000 x G, 2 min, $4{ }^{\circ} \mathrm{C}$ ), possibilitando a realização da gel filtração a seco. Em seguida a coluna foi cuidadosamente preenchida com o sistema experimental e o sistema controle (cada qual em sua respectiva coluna) e submetida às mesmas condições de centrifugação citadas. As amostras que passaram pela coluna contendo os peptídeos capturados e o controle foram coletadas e armazenadas.

Em outro experimento envolvendo este procedimento de captura com a EP 24.16, foram empregadas as quantidades de $100 \mu \mathrm{g}$ e $150 \mu \mathrm{g}$ de enzima cataliticamente inativa, descritos a seguir.

\subsection{Junção das amostras provenientes do experimento de captura de peptídeos com 100 e $150 \mu$ de neurolisina (EP 24.16) inativa, obtenção do perfil cromatográfico por HPLC, fracionamento e coleta manual}

As amostras oriundas dos experimentos de captura realizados com 100 e $150 \mu \mathrm{g}$ de EP 24.16 inativa foram misturadas. Então, $10 \mu \mathrm{L}$ deste mix foi submetido à análise por HPLC em fase-reversa C-18. O gradiente utilizado foi de 10-60\% de solvente B em 40 minutos (solvente A: $\mathrm{H}_{2} \mathrm{O} / \mathrm{TFA}$ 0,01\% e solvente B: Acn/solvente A 9:1) sob fluxo de 1,0 mL/min. Após determinação das regiões de coleta, o restante do mix foi injetado e em seguida manualmente coletado.

As amostras coletadas foram secas em sistema Speed-Vac e armazenadas a $-20{ }^{\circ} \mathrm{C}$ e posteriormente, submetidas à análise por espectrometria de massas para a determinação das sequências primárias. 


\subsection{Screening das frações peptídicas por atividade moduladora das enzimas timet oligopeptidase (EP 24.15) e neurolisina (EP 24.16)}

O pool peptídico da fração de baixa massa molecular da peçonha do escorpião, oriundo da quantidade inicial de $10 \mathrm{mg}$, foi fracionado em sistema HPLC de fase-reversa C18 Shimadzu, Prominence (Shimadzu Corporation, Tóquio, Japão). O gradiente utilizado foi de $10-60 \%$ de solvente $B$ em 40 minutos (solvente $\mathrm{A}: \mathrm{H}_{2} \mathrm{O} / \mathrm{TFA} 0,01 \%$ e solvente $\mathrm{B}$ : Acn/solvente A 9:1) sob fluxo de 1,0 mL/min. Assim, a velocidade de troca de B/min foi de $1,2 \% \mathrm{~B} / \mathrm{min}$.

Após a obtenção das frações, as mesmas foram secas em sistema de Speed-Vac, ressuspendidas em $50 \mu \mathrm{L}$ de tampão $\operatorname{PBS}(\mathrm{pH} 7,4)$ e submetidas à testes enzimáticos utilizando substrato fluorescente QFS (7-methoxycoumarin-4-acetyl-Pro-Leu-Gly-Pro-dLys(2,4-dinitrophenyl) e as peptidases selvagens recombinantes (SHRIMPTON et al., 1997). Foram utilizados 7,5 ng de enzima, $10 \mu \mathrm{M}$ de substrato (valor referente ao $\mathrm{K}_{\mathrm{m}}$ ), $10 \mu \mathrm{L}$ das soluções individuais das 15 frações e tampão PBS (pH 7,4) suficientes para $100 \mu \mathrm{L}$ de volume final. As medidas de seus potenciais inibitórios foram realizadas em duplicata.

As frações que apresentaram possíveis inibições foram selecionadas, secas e ressuspendidas em $100 \mu \mathrm{L}$ de água Milli- $\mathrm{Q}^{\circledR}$ para novas purificações em sistema HPLC de fase reversa C-18. Inicialmente, foram feitos perfis analíticos com $5 \mu \mathrm{L}$ de cada fração e, após, foram injetados os $95 \mu \mathrm{L}$ restantes para coleta manual. Cada fração foi submetida à gradientes diferentes objetivando uma melhor separação de seus componentes.

A fração 6 foi separada pelo gradiente $15-40 \% \mathrm{~B} / 40 \mathrm{~min}(\mathrm{Vel} .=0,625 \% \mathrm{~B} / \mathrm{min})$, as frações 7, 11, 12 e 13 foram separada pelo gradiente $15-30 \% \mathrm{~B} / 30 \mathrm{~min}$ (Vel. = 0,5 B/min) e as frações 14 e 15 foram separadas pelo gradiente 20-35\% B/ $30 \mathrm{~min}$ (Vel. = 0,5 B/min).

Após a recromatografia em HPLC das frações que apresentaram peptídeos moduladores da EP 24.15 e EP 24.16, as novas subfrações foram analisadas em fluorímetro como descrito acima. As novas subfrações que apresentaram interação com as oligopeptidases foram submetidas à espectrometria de massas para a determinação de suas sequências primárias.

\subsection{Sequenciamento dos peptídeos por espectrometria de massas (LC-MS/MS)}

A análise foi realizada em LC-MS/MS em um espectrômetro de massas Synapt G1 (Waters). A fração peptídica foi ressuspendida em água Milli- $\mathrm{Q}^{\circledR}$ e 2 a $5 \mu \mathrm{L}$ foram aplicadas 
em uma coluna Symmetry C18 trapping $(180 \mu \mathrm{m} \times 20 \mathrm{~mm}$, Waters). A amostra foi dessanilizada por 15 minutos e os peptídeos capturados separados por eluição com gradiente de água/acetonitrila e 0,1\% de ácido fórmico BEH 130 - coluna C-18 (100 ㅆm x 100 mm, Waters), como descrito em Berti et al. (2009). Os dados foram obtidos em um modo dado dependente e os peptídeos selecionados dissociados através de colisões com argônio. As condições experimentais incluíram um fluxo de $600 \mathrm{~nL} / \mathrm{min}$, nanoflow capillary voltage de $3,5 \mathrm{kV}$, temperatura do bloco de $100{ }^{\circ} \mathrm{C}$ e cone voltage de $100 \mathrm{~V}$. O espectro foi analisado manualmente como descrito em Rioli et al. (2003) com auxílio do programa PepSeq.

\subsection{Síntese dos peptídeos}

A síntese dos peptídeos foi realizada pelo Dr. Robson Lopes Melo do Laboratório Especial de Pré-formulação (LETA - Instituto Butantan). A síntese foi feita de acordo com Atherton e Sheppard (1989) com grau de pureza de 95\%.

3.10 Testes para a identificação de substratos dentre os peptídeos sintetizados perante as enzimas timet oligopeptidase (EP 24.15), neurolisina (EP 24.16), neprilisina (EP 24.11) e enzima conversora de angiotensina (ECA)

Para este experimento empregamos as enzimas recombinantes EP 24.15 e EP 24.16 e as enzimas comerciais recombinantes EP 24.11 humana (R\&D Systems Inc., Minneapolis, MN, EUA) e ECA I de pulmão de coelho (Sigma-Aldrich), onde realizamos os procedimentos para a observação de hidrólise em caso de substratos. $50 \mu \mathrm{M}$ de cada peptídeo foram incubados individualmente durante 4 horas a $37{ }^{\circ} \mathrm{C}$ com 7,5 ng das respectivas enzimas. Como controle, utilizamos $25 \mu \mathrm{M}$ de bradicinina, substrato em comum dessas enzimas. Após este período, as reações foram cessadas com a adição de $20 \mu \mathrm{L}$ de tampão A $(0,01 \%$ de TFA diluído em 1 L de água Milli- ${ }^{\circledR}$ ) e analisadas em HPLC. O gradiente utilizado foi de 10-60\% de solvente B em 40 minutos (solvente $\mathrm{A}: \mathrm{H}_{2} \mathrm{O} / \mathrm{TFA}$ 0,01\% e solvente $\mathrm{B}$ : Acn/solvente A 9:1) sob fluxo de $1,0 \mathrm{~mL} / \mathrm{min}$.

3.11 Testes cinéticos para a determinação de inibidores da atividade enzimática das enzimas timet oligopeptidase (EP 24.15), neurolisina (EP 24.16), neprilisina (EP 24.11) e enzima conversora de angiotensina (ECA)

Para os testes cinéticos, realizamos a incubação dos peptídeos sintetizados com as enzimas e os seus respectivos substratos fluorescentes (FRET - Fluorescence Energy 
Resonance Transfer), os quais são vastamente empregados em testes cinéticos enzimáticos, devido a ser um método relativamente fácil, rápido e sensível, cujo o princípio básico consiste em um grupo fluorescente doador de elétrons, ácido orto-aminobenzoico (Abz), ligado a um dos resíduos de aminoácidos do grupo carboxila terminal do peptídeo e que transfere energia a um aceptor responsável por "apagar" a fluorescência, fluorescência N-(2,4-dinitrofenil)etilenodiamina (EDDnp), ligado em outro resíduo. Assim que ocorre a clivagem e a separação destes grupos, a fluorescência é detectada por um fluorímetro, podendo ser quantificada e analisada conforme o objetivo experimental.

(CARMONA et al., 2009). Utilizamos concentrações variadas de cada peptídeo e comparamos o poder de modulação perante a enzima testada. Para as enzimas EP 24.15 e EP 24.16 utilizamos as mesmas quantidades e o mesmo substrato já citado. Para a enzima EP 24.11, foram utilizados 7,5 ng da enzima com 3,5 $\mu \mathrm{M}$ do substrato Abz-RGFK (Dnp)-OH (BARROS et al., 2007) em tampão 0,5 mM de Tris $\mathrm{HCl}$ pH 7,5 com volume final de $100 \mu \mathrm{L}$. Para a ECA I foram utilizados 3 ng de enzima com $10 \mu \mathrm{M}$ de substrato Abz-FRK(Dnp)P-OH) em tampão Tris $\mathrm{HCl} 100 \mathrm{mM}, \mathrm{NaCl} 50 \mathrm{mM}$ contendo $10 \mu \mathrm{M}$ de $\mathrm{ZnCl}_{2} \mathrm{pH}$ 7,0 com volume final de $100 \mu \mathrm{L}$ (ARAUJO et al., 1999).

Para a determinação da constante de inibição $\left(\mathrm{K}_{\mathrm{i}}\right)$ e do mecanismo de ação dos peptídeos selecionados em relação às enzimas EP 24.15 e EP 24.16, foram utilizadas quatro concentrações de seus respectivos substratos fluorescentes e duas concentrações de peptídeos, mantendo-se a concentração de enzima constante $(7,5$ ng em $100 \mu \mathrm{L})$. O controle sem peptídeo também foi realizado. Foi construído o gráfico de Lineweaver-Burk (1/V x 1/[S]) e de acordo com o mecanismo apresentado o $\mathrm{K}_{\mathrm{i}}$ foi calculado como descrito por Segel (1975), segundo a equação:

$$
\mathrm{K}_{\mathrm{i}(\text { app })}=[\mathrm{i}] /\left[\left(\mathrm{v}_{0} / \mathrm{v}_{\mathrm{i}}\right)-1\right] \text { e } \mathrm{K}_{\mathrm{i}}=\mathrm{K}_{\mathrm{i}(\mathrm{app})} /\left[\left(\mathrm{K}_{\mathrm{m}} /[\mathrm{S}]\right)+1\right]
$$

Onde; [i] = concentração de inibidor; $\left(\mathrm{v}_{0} / \mathrm{v}_{\mathrm{i}}\right)=$ velocidades de hidrólise na ausência e presença de inibidor, respectivamente e; $\mathrm{K}_{\mathrm{m}} /[\mathrm{S}]=$ relação entre o $\mathrm{K}_{\mathrm{m}}$ do substrato e sua concentração.

Para a EP 24.11, a determinação do mecanismo de inibição foi realizada através do método proposto pelo trabalho de Cornish-Bowden (1974) comparando-se os gráficos s/v X [i] e 1/v X [i] para a determinação dos mecanismos inibitórios. 


\subsection{Possíveis alterações da sensibilidade dolorosa induzida por novos substratos e/ou inibidores para timet oligopeptidase (EP 24.15) e neurolisina (EP 24.16) obtidos das frações de baixa massa molecular do veneno do escorpião Tityus serrulatus}

Os experimentos farmacológicos descritos abaixo foram aprovados pelo comitê de ética no uso de animais do Instituto Butantan (CEUAIB - protocolo No. 863/11).

\subsubsection{Animais}

Foram utilizados camundongos Swiss, machos, pesando entre 22 e 26 g, ou ratos Wistar, machos, pesando entre 160 e $180 \mathrm{~g}$, fornecidos pelo Biotério Central do Instituto Butantan. Os animais foram mantidos em gaiolas com acesso livre a água e ração. A temperatura e umidade do biotério foram controladas. $\mathrm{O}$ ciclo claro-escuro do biotério foi mantido como de 12 horas cada. Os protocolos experimentais estão de acordo com os Princípios Éticos de Experimentação Animal adotado pelo Colégio Brasileiro de Experimentação Animal (COBEA) e foram aprovados pela comissão de ética no uso de animais do Instituto Butantan (CEUAIB).

\subsubsection{Ensaios de nocicepção}

Para avaliar a possível atividade antinociceptiva dos peptídeos, foi utilizado o modelo de pressão de pata de ratos (RANDALL; SELITTO, 1957). Para a execução deste teste foi utilizado analgesímetro Ugo Basile (Ugo Basile Srl, Gemonio, Varese, Itália), que gera aumento linear da força (em gramas, $16 \mathrm{~g} / \mathrm{s}$ ) aplicada sobre a superfície dorsal da pata do animal até que esse retire a pata. O reflexo de retirada da pata é considerado representativo do limiar nociceptivo. A pressão necessária para que esse animal exiba tal resposta é registrada em gramas. Para avaliar a possível atividade antinociceptiva, os peptídeos foram administrados na presença de hiperalgesia inflamatória. A hiperalgesia foi induzida por administração intraplantar de $0,1 \mathrm{~mL}$ de salina estéril contendo carragenina (200 $\mu \mathrm{g} / \mathrm{pata})$. O limiar nociceptivo foi medido antes e em diferentes tempos após a injeção da carragenina. Os peptídeos (20 $\mu \mathrm{g} / \mathrm{pata})$ foram injetados $150 \mathrm{~min}$ após a carragenina.

Para avaliar a capacidade de alterar, per se, a sensibilidade dolorosa dos animais, os peptídeos foram injetados por via i.pl. (20 $\mu \mathrm{g} /$ pata) na ausência de qualquer estímulo inflamatório. 
3.12.3 Inflamação: Reatividade vascular e alterações na interação leucócito-endotélio induzidas pelos peptídeos da peçonha do Tityus serrulatus na microcirculação do músculo cremaster de camundongos

Em camundongos anestesiados com uma associação de Cloridrato de Quetamina e Xilazina (8,3mg e 3,3mg/100g de peso corpóreo, respectivamente) foi feita uma incisão na bolsa escrotal para o isolamento do músculo cremaster. Este foi aberto e separado do epidídimo, permitindo a sua distensão para visualização ao microscópio. Após esse procedimento, a preparação foi mantida sobre uma placa com temperatura controlada $\left(37^{\circ} \mathrm{C}\right)$, dotada de uma área transparente, através da qual o leito microvascular foi visualizado (BAEZ, 1973). A preparação foi analisada em um microscópio de luz Zeiss Axioskop (Carl Zeiss AG, Oberkochen, Alemanha) com objetiva 10 x, acoplado a uma câmera para captação de imagens JVC TK-C600 (JVC Corporation, Yokohama, Japão). As imagens foram transmitidas a um aparelho de televisão ligado a um vídeo cassete, e a um computador provido de uma placa de captura de vídeo, permitindo a captação de imagens estáticas e dinâmicas, e posterior gravação em DVD. As medições foram feitas com auxílio do programa de análise de imagens KONTRON, KS 300 (Carl Zeiss). Os peptídeos foram aplicados topicamente $(20 \mu \mathrm{g} / 20 \mu \mathrm{L}$ de salina estéril) sobre o músculo cremaster 10 minutos após a exposição do leito micro circulatório, período de estabilização da preparação. Vênulas pós-capilares (20 e $40 \mu \mathrm{m}$ ), num segmento de $100 \mu \mathrm{m}$, foram selecionadas em cada animal, sendo analisados os diâmetros desses vasos e os leucócitos em rolling. O rolling foi contado durante um período de 3 minutos, nos tempos 10, 20 e 30 minutos após a aplicação dos peptídeos na microcirculação. Um grupo de quatro a seis animais foi empregado para cada experimento. 


\section{RESULTADOS}

\subsection{Expressão das enzimas timet oligopeptidase (EP 24.15) e neurolisina (EP 24.16) recombinantes selvagens e cataliticamente inativas e testes para a determinação da atividade enzimática}

As enzimas foram expressas e em seguida purificadas. A pureza foi determinada através de gel em SDS-PAGE, conforme banda única demonstrada (Figura 9).

As amostras foram quantificadas pelo método de Bradford (1976), aliquotadas e armazenadas a $-80^{\circ} \mathrm{C}$.

Figura 9 - Gel da expressão das enzimas empregadas nos experimentos

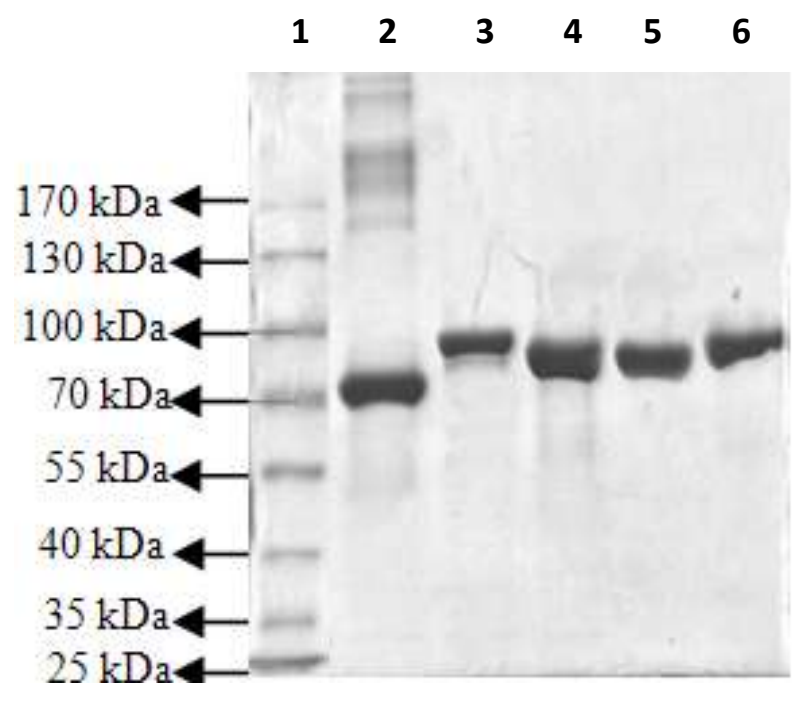

SDS-Page das proteínas recombinantes purificadas em gel de poliacrilamida (8\%). 1) Padrão molecular (3 $\mu \mathrm{L})$, 2) BSA (albumina do soro bovino) $(10 \mu \mathrm{g}), 3)$ EP 24.15 recombinante selvagem $(7,5 \mu \mathrm{g})$, 4) EP 24.16 recombinante selvagem $(10 \mu \mathrm{g}), 5)$ EP 24.16 recombinante mutante $(10 \mu \mathrm{g}), 6)$ EP 24.15 recombinante mutante $(7,5 \mu \mathrm{g})$, corado com Coomassie Blue. As respectivas proteínas se apresentaram puras conforme demonstrado acima.

Visando a observação da manutenção da atividade catalítica por parte das enzimas selvagens expressas, foi realizado o teste de atividade enzimática com o emprego do substrato fluorescente QFS. As enzimas recombinantes selvagens da EP 24.15 e EP 24.16 apresentaram atividade perante o substrato. $\mathrm{O}$ mesmo teste foi realizado para as enzimas recombinantes cataliticamente inativas, as quais não apresentaram atividade catalítica perante o substrato empregado. 


\subsection{Fracionamento da peçonha do Tityus serrulatus para a obtenção da fração de baixa massa molecular e quantificação do pool peptídico empregando fluorescamina}

Após aplicação do protocolo empregando $10 \mathrm{mg}$ de peçonha bruta liofilizada, a fração contendo peptídeos de até $3 \mathrm{kDa}$ foi obtida e armazenada a $-20{ }^{\circ} \mathrm{C}$.

O mesmo procedimento foi aplicado com o emprego de $40 \mathrm{mg}$ iniciais de peçonha bruta liofilizada. Após a obtenção, a amostra oriunda deste experimento foi quantificada através do uso da fluorescamina. A concentração peptídica obtida foi de 5,35 $\mu \mathrm{g} / \mu \mathrm{L}$.

\subsection{Isolamento dos possíveis substratos e/ou inibidores peptídicos das enzimas timet oligopeptidase (EP 24.15) e neurolisina (EP 24.16) a partir da fração de baixa massa molecular}

\subsubsection{Técnica de captura de peptídeos com o emprego das enzimas timet oligopeptidases (EP 24.15) e neurolisina (EP 24.16) cataliticamente inativas}

A técnica foi inicialmente empregada na fração de baixa massa molecular proveniente de $10 \mathrm{mg}$ de peçonha liofilizada. Conforme demonstrado na Figura 10, é possível observar um aumento da intensidade de algumas frações em relação ao controle, que é composto apenas do tampão e do pool peptídico. Com isso, as enzimas inativas foram capazes de interagirem com alguns peptídeos contidos na fração de peçonha analisada. As frações em destaque foram coletadas, secas em sistema Speed-Vac e armazenadas a $-20^{\circ} \mathrm{C}$. As amostras selecionadas foram encaminhadas para análises por espectrometria de massas. 
Figura 10 - Cromatograma da interação da fração de baixa massa molecular do veneno de Tityus serrulatus com as enzimas inativas EP 24.15 e EP 24.16.
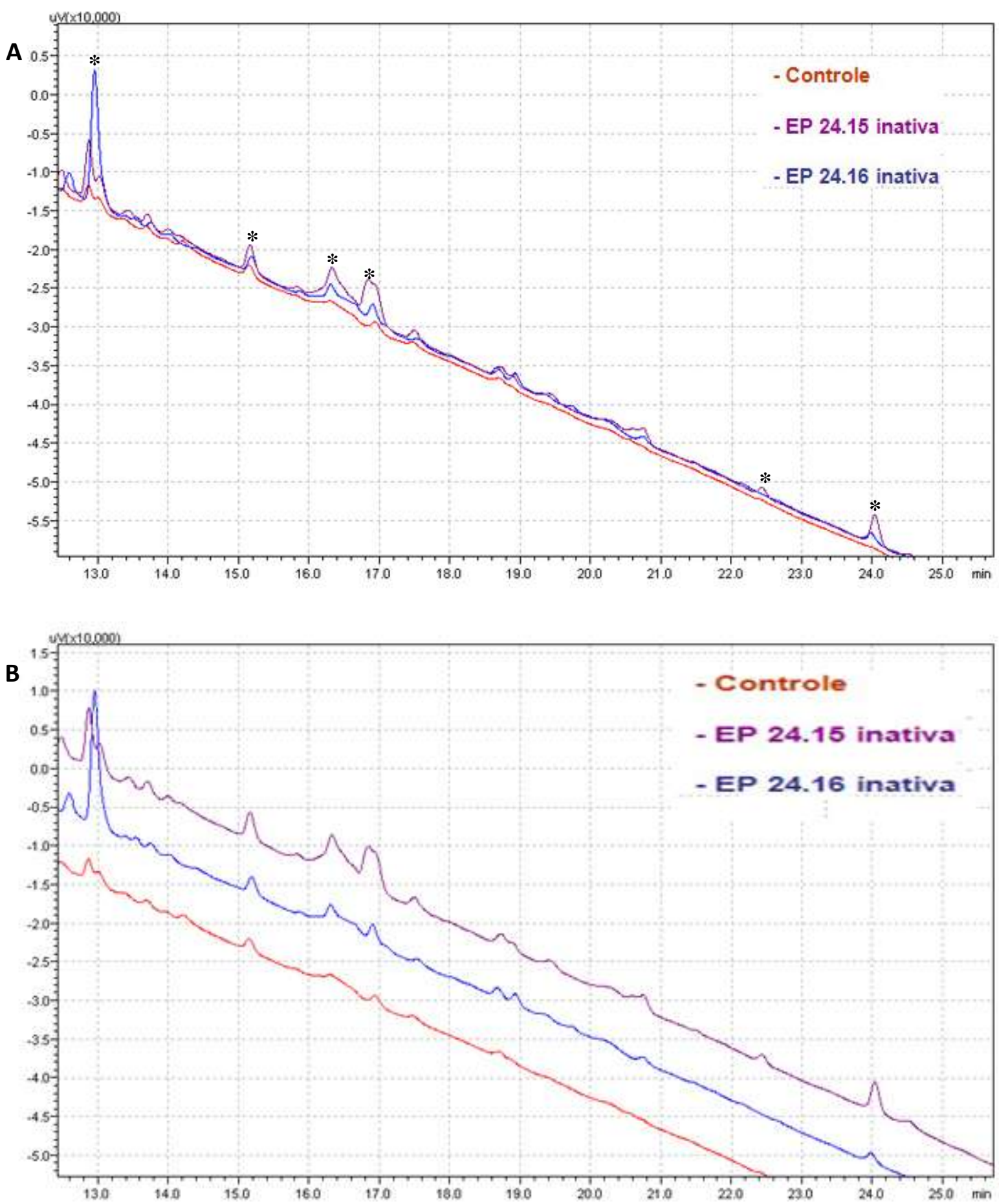

HPLC fase-reversa C-18 (Shimadzu, Prominence). O gradiente inicial utilizado de 10-60\% de solvente B em 40 minutos (solvente A: $\mathrm{H}_{2} \mathrm{O} /$ TFA 0,01\% e solvente B: Acn/solvente A 9:1) sob fluxo de 1,0 mL/min. Os picos demarcados com (*) são os que apresentaram aumento pela ação da captura (A). Em B é observado o mesmo cromatograma demonstrado em A, porém com um aumento de imagem em um determinado intervalo, entre $10 \mathrm{e}$ 19 minutos, onde é possível notar a diferença dos picos experimentais em relação ao controle. 
4.3.2 Emprego da técnica de captura de peptídeos com a enzima neurolisina (EP 24.16) cataliticamente inativa

Uma vez que a quantidade de amostras peptídicas obtidas pela metodologia descrita acima não foi suficiente para serem detectadas por espectrometria de massas, a técnica de captura de peptídeos pela EP 24.16 cataliticamente inativa foi realizada novamente, mas a quantidade de enzima empregada foi aumentada em sistemas que utilizaram 100 e $150 \mu \mathrm{g}$. Os sistemas foram testados perante a fração de baixa massa molecular proveniente de $40 \mathrm{mg}$ da peçonha liofilizada bruta. Este experimento foi realizado utilizando $30 \mu \mathrm{L}$ de pool peptídico, representando $160,5 \mu \mathrm{g}$ de peptídeos totais. O resultado obtido com o emprego dessas duas quantidades de enzimas demonstrou que a quantidade capturada usando $150 \mu \mathrm{g}$ foi um pouco mais eficaz do que a usando $100 \mu \mathrm{g}$, conforme observado na Figura 11.

Figura 11 - Novo cromatograma da interação da fração de baixa massa molecular do veneno de Tityus serrulatus com as enzimas inativas EP 24.16

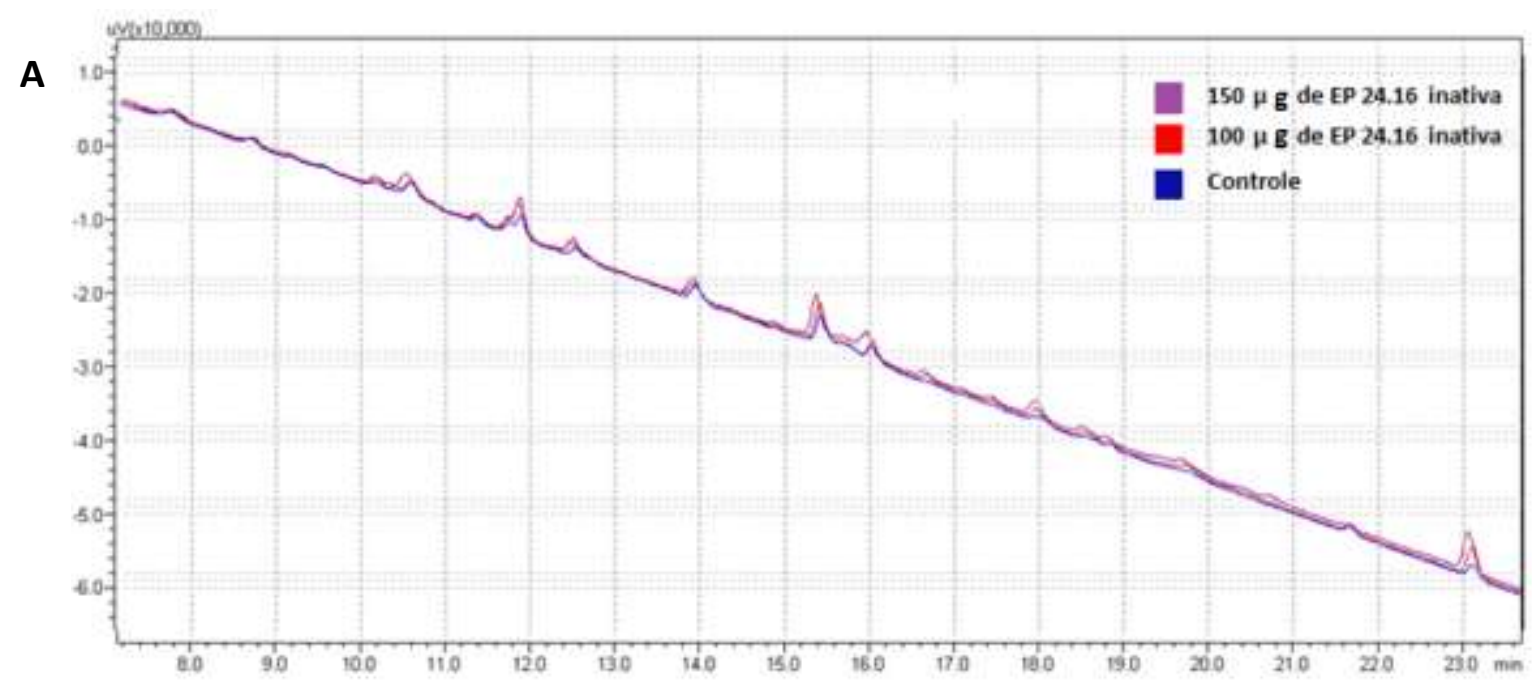


B

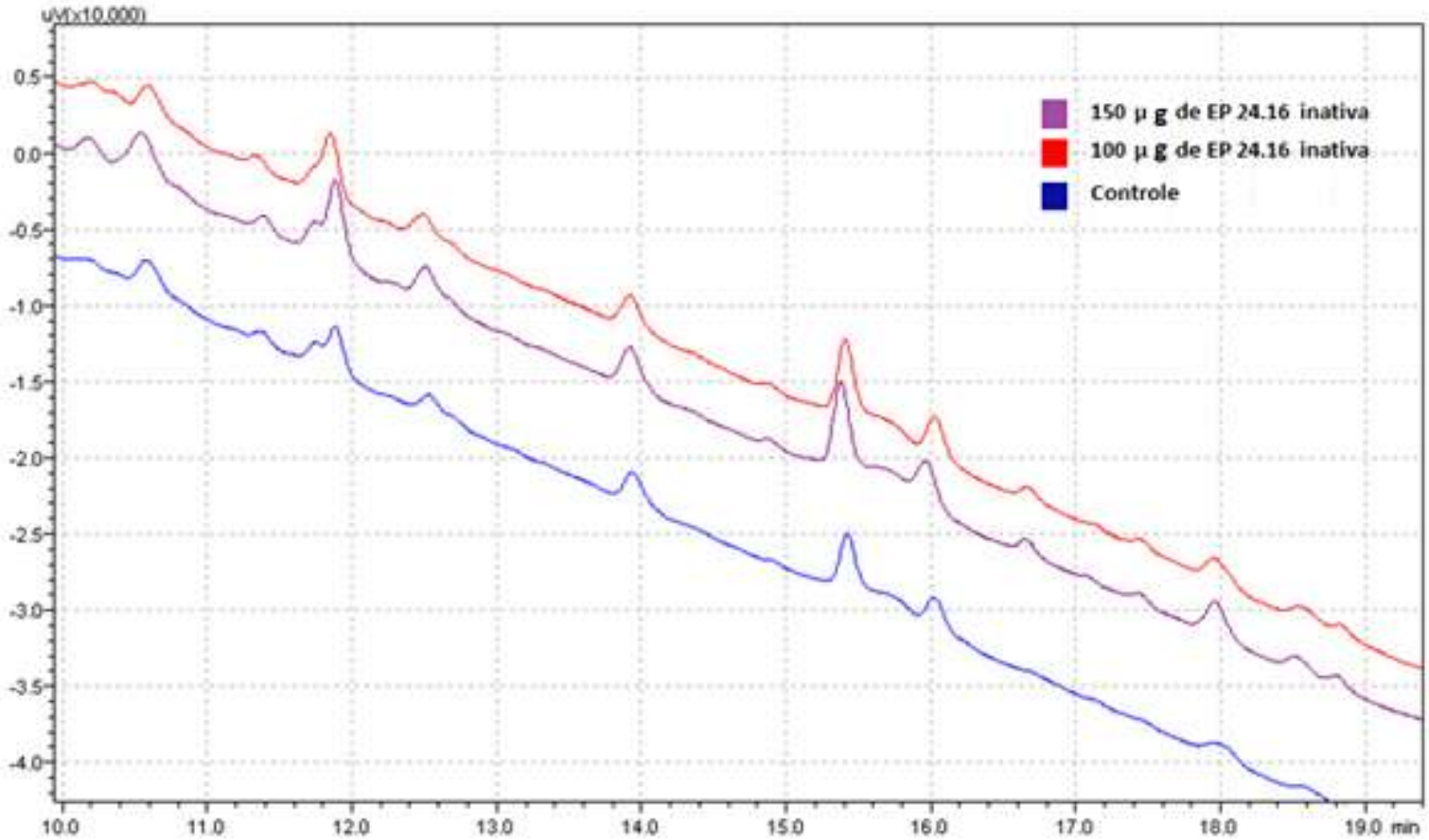

HPLC fase-reversa C-18 (Shimadzu, Prominence). O gradiente foi o mesmo empregado anteriormente. Em A é possível notar novamente um aumento das frações experimentais em relação ao controle. Em B, imagem aumentada entre o intervalo de 13 a 25 minutos, fica evidenciada a melhor eficácia do emprego de $150 \mu \mathrm{g}$ de enzima, com um aumento de peptídeos capturados, demonstrado pelo aumento das frações.

As amostras provenientes de 100 e $150 \mu \mathrm{g}$ foram misturadas, dando origem a uma amostra denominada mix. Uma parte desta amostra foi submetida análise por HPLC resultando num perfil cromatográfico mostrado na Figura 12. 
Figura 12 - Junção das frações provenientes dos experimentos empregando 100 e $150 \mu \mathrm{g}$ de EP 24.16 inativa

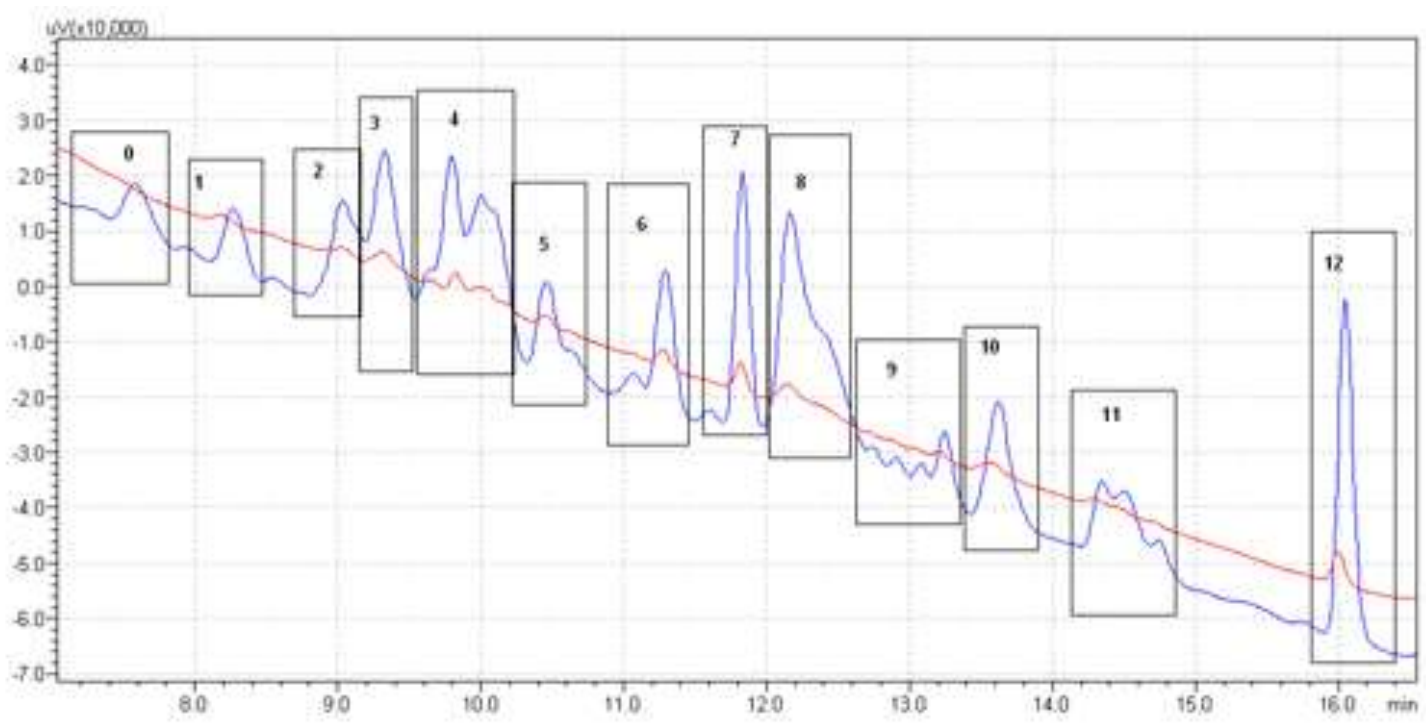

HPLC fase-reversa C-18 realizado nos mesmos padrões já descritos. Este perfil foi utilizado para designar quais frações seriam coletadas. A linha azul corresponde ao perfil do mix e a linha vermelha é o perfil do pool peptídico controle.

Este novo perfil foi comparado com o anteriormente obtido (Figura 13, adaptação da Figura 11 A), e a possível localização das frações obtidas anteriormente separadamente determinadas no quadro da Figura 14. As comparações para as identificações foram feitas levando em conta os tempos de retenção.

Figura 13 - Figura 11 A adaptada para demonstração das regiões correspondentes

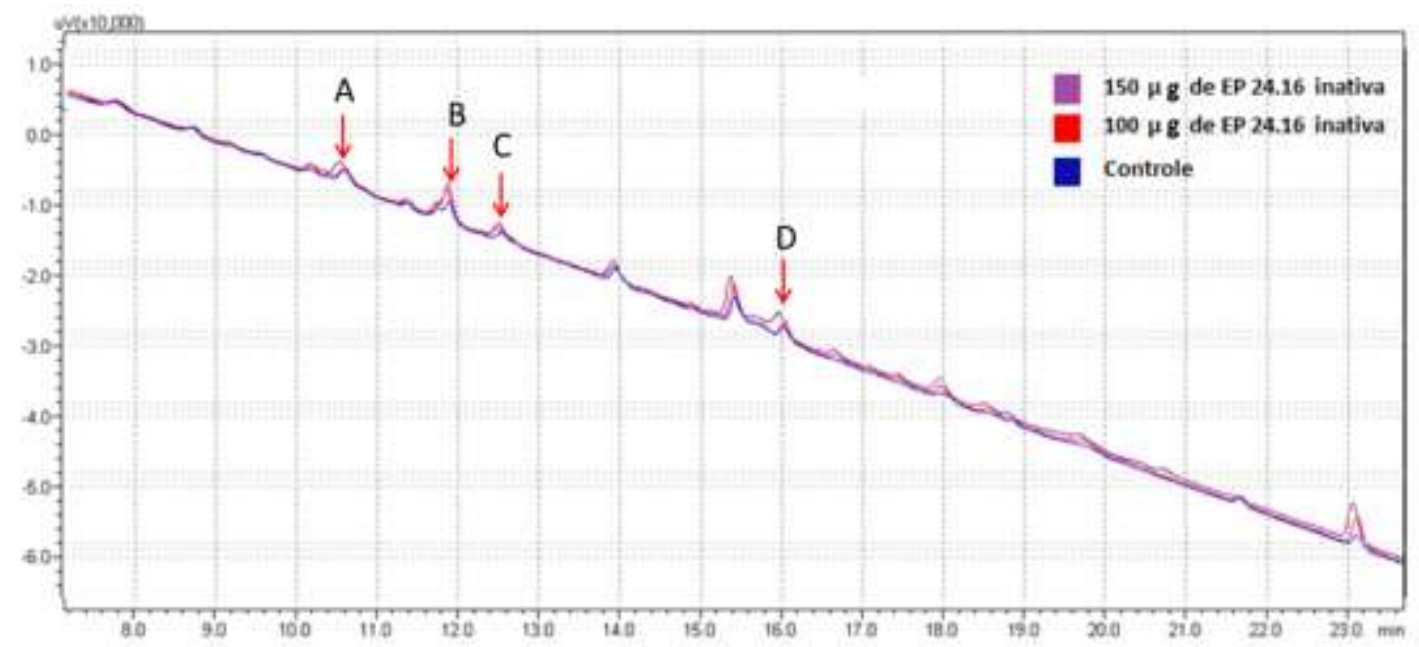

As setas vermelhas demonstram as frações selecionadas para análise por espectrometria de massas com a mistura dos pools de 100 e $150 \mu \mathrm{g}$. 
Figura 14 - Quadro comparando as frações da Figura 12 em relação à Figura 13.

\begin{tabular}{|c|c|}
\hline Amostra mix (Figura 12) & Amostra experimento (Figura 13) \\
\hline 4 & $\mathrm{~A}$ \\
\hline 7 & $\mathrm{~B}$ \\
\hline 8 & $\mathrm{C}$ \\
\hline 12 & $\mathrm{D}$ \\
\hline
\end{tabular}

Relação entre a comparação do experimental usando 100 e $150 \mu \mathrm{g}$ de EP 24.16 inativa para a captura de peptídeos com as amostras enviadas para sequenciamento por espectrometria de massas referente ao pool oriundo da junção das frações restantes de 100 e $150 \mu \mathrm{g}$ de EP 24.16. As amostras das frações 4, 7, 8 e 12 da Figura 12 foram selecionadas para análise por espectrometria de massas, pois foram referentes às frações que aumentaram na Figura 12. A seleção foi realizada em relação à comparação dos tempos de retenção entre as frações juntas (Figura 12) e as frações separadas (Figura 13).

As frações selecionadas foram submetidas à análise por espectrometria de massas (Figura 15).

Figura 15 - Quadro com as massas obtidas e selecionadas por MS/MS das frações analisadas

\begin{tabular}{|c|c|c|c|c|}
\hline \multirow{4}{*}{} & Fração 4 & Fração 7 & Fração 8 & Fração 12 \\
\cline { 2 - 5 } & $423,2^{*}$ & 402,1 & 430,1 & 386,6 \\
\cline { 2 - 5 } & 484,2 & 491,1 & 452,1 & 734,2 \\
\cline { 2 - 5 } & 493,2 & 549,1 & 456,2 & 1467,4 \\
\cline { 2 - 5 } Massas & 559,3 & 564,2 & 492,1 & - \\
\cline { 2 - 5 } obtidas e & 536,2 & 604,2 & 499,2 & - \\
\cline { 2 - 5 } selecionadas & - & 677,3 & 549,2 & - \\
\cline { 2 - 5 } no MS & - & 717,2 & 569,3 & - \\
\cline { 2 - 5 } (Da) & - & - & 566,1 & - \\
\cline { 2 - 5 } & - & - & 591,2 & - \\
\cline { 2 - 5 } & - & - & 608,3 & - \\
\cline { 2 - 5 } & - & - & 652,2 & - \\
\cline { 2 - 5 } & - & - & 725,3 & - \\
\cline { 2 - 5 } & - & - & 859,2 & - \\
\hline
\end{tabular}

Essas frações foram selecionadas e encaminhadas para a realização do MS/MS para fragmentação. Todas estas massas obtidas estão sendo aguardadas para o sequenciamento. A amostra com um asterisco $\left({ }^{*}\right)$ representa a massa referente ao FTR.

Em relação às massas obtidas acima, a massa 423,2 Da contida no pico 4 é referente ao peptídeo FTR (Figura 23 B), o qual foi identificado tanto por captura peptídica assim como por screening em relação a atividade biológica. 
Sobre as análises referentes à fração 13, foi sequenciado um pentapeptídeo constituído por XXSAF, onde o $\mathrm{X}$ poderia ser tanto uma leucina como uma isoleucina. $\mathrm{O}$ software empregado deu a sequência inicial como LLSAF (Figura 16).

Figura 16 - Espectro de massas do peptídeo XXSAF encontrado no P13 proveniente do screening por atividade enzimática

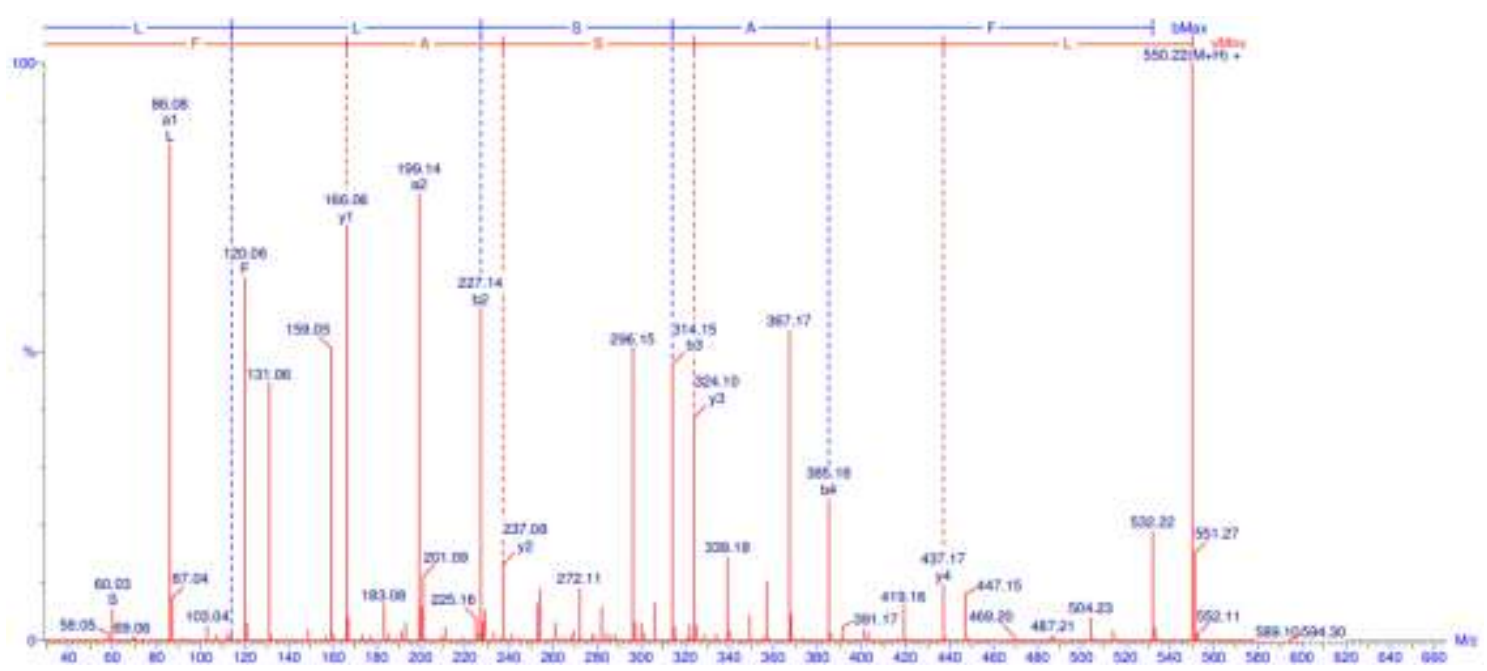

Figura 17 - Espectro do peptídeo FTR encontrado na amostra 4 (Figura 12) referente ao pico A (Figura 13).

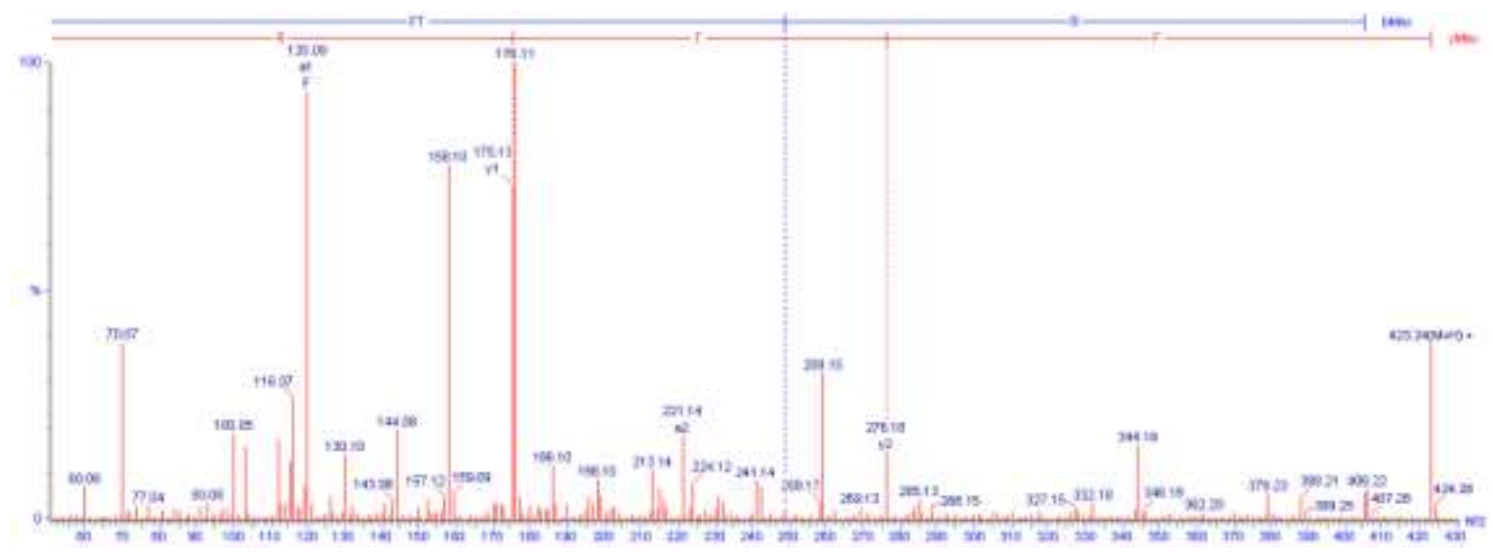

4.3.3 Isolamento de peptídeos através da interação com as oligopeptidases selvagens e emprego de substratos FRETs

O perfil cromatográfico do pool peptídico foi definido através do emprego do HPLC, onde quinze frações foram determinadas e coletadas para análises utilizando as enzimas selvagens e o substrato FRET (Figura 18). 
Figura 18 - Cromatograma da fração de baixa massa molecular do veneno do T. serrulatus após HPLC em fase-reversa C-18 (Shimadzu, Prominence).

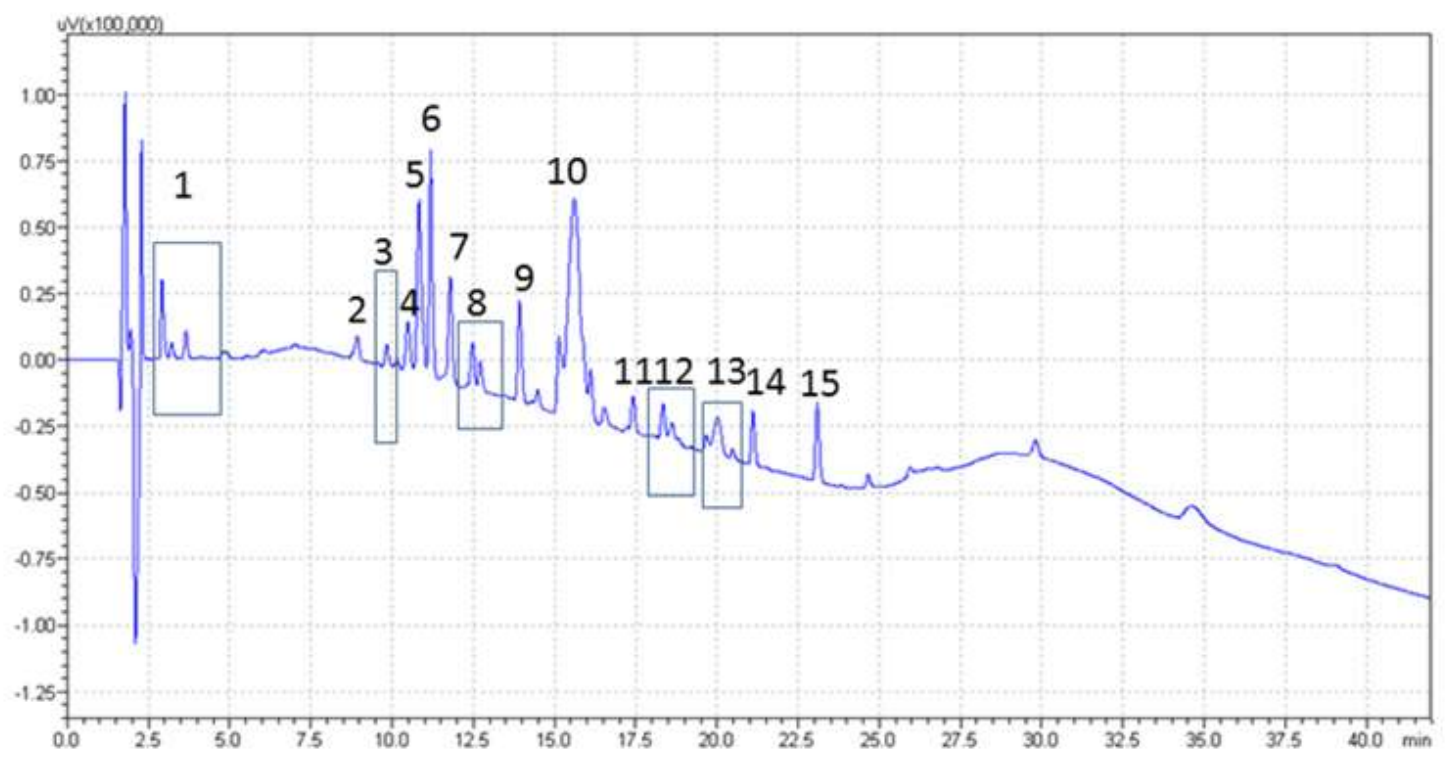

O gradiente foi o mesmo usado anteriormente. Houve a divisão em 15 frações, as quais foram destinadas a coleta. As demarcações quadriculadas são referentes a grupos de frações juntamente coletados. As frações coletadas foram submetidas a testes de cinética enzimática envolvendo as enzimas EP 24.15 e EP 24.16 selvagens.

As frações coletadas foram testadas perante a atividade das enzimas EP 24.15 e EP 24.16, objetivando verificar a interação dos peptídeos das frações selecionadas em relação às enzimas. O resultado pode ser observado no quadro da Figura 19. 
Figura 19 - Porcentagem de inibição relativa das atividades enzimáticas da EP 24.15 e da EP 24.16

\begin{tabular}{|c|c|c|}
\hline Fração & EP 24.15 & EP 24.16 \\
\hline 1 & SI & SI \\
\hline 2 & SI & SI \\
\hline 3 & SI & SI \\
\hline 4 & $15 \%$ & $35 \%$ \\
\hline 5 & SI & SI \\
\hline 6 & $50 \%$ & $40 \%$ \\
\hline 7 & $25 \%$ & $22 \%$ \\
\hline 8 & SI & SI \\
\hline 9 & SI & SI \\
\hline 10 & SI & SI \\
\hline 11 & $74 \%$ & $22 \%$ \\
\hline 12 & $72 \%$ & $55 \%$ \\
\hline 13 & $82 \%$ & $88 \%$ \\
\hline 14 & $38 \%$ & $17 \%$ \\
\hline 15 & $11 \%$ & $55 \%$ \\
\hline
\end{tabular}

SI= Sem inibição relativa

Neste experimento foi comparada a capacidade das frações coletadas de causarem inibição das enzimas EP 24.15 e EP 24.16 em sistemas separados. Houve seleção das frações 6, 7, 11, 12, 13, 14 e 15 as quais apresentaram maior inibição relativa e estão em destaque acima.

O screening sugeriu que dentre as 15 frações coletadas, oito foram capazes de modularem a atividade das enzimas. Dentre estas frações, sete foram selecionadas em relação ao poder inibitório relativo perante as enzimas, e foram submetidas a uma nova etapa de purificação em HPLC utilizando diferentes gradientes, objetivando a obtenção de uma melhor separação das amostras.

Após a realização da nova purificação (Figura 20), novas frações surgiram para serem coletadas. As novas subfrações foram testadas perante a enzima EP 24.16 recombinante selvagem (Figura 21). As novas subfrações foram denominadas: 6P, 6P1, 6P2, 7P, 11P, 12P. 12P1, 12P2, 13P, 13P1, 14P e 15P. 
Figura 20 - Cromatogramas das frações selecionadas com diferentes gradientes para uma melhor separação ("abertura" dos picos obtidos)

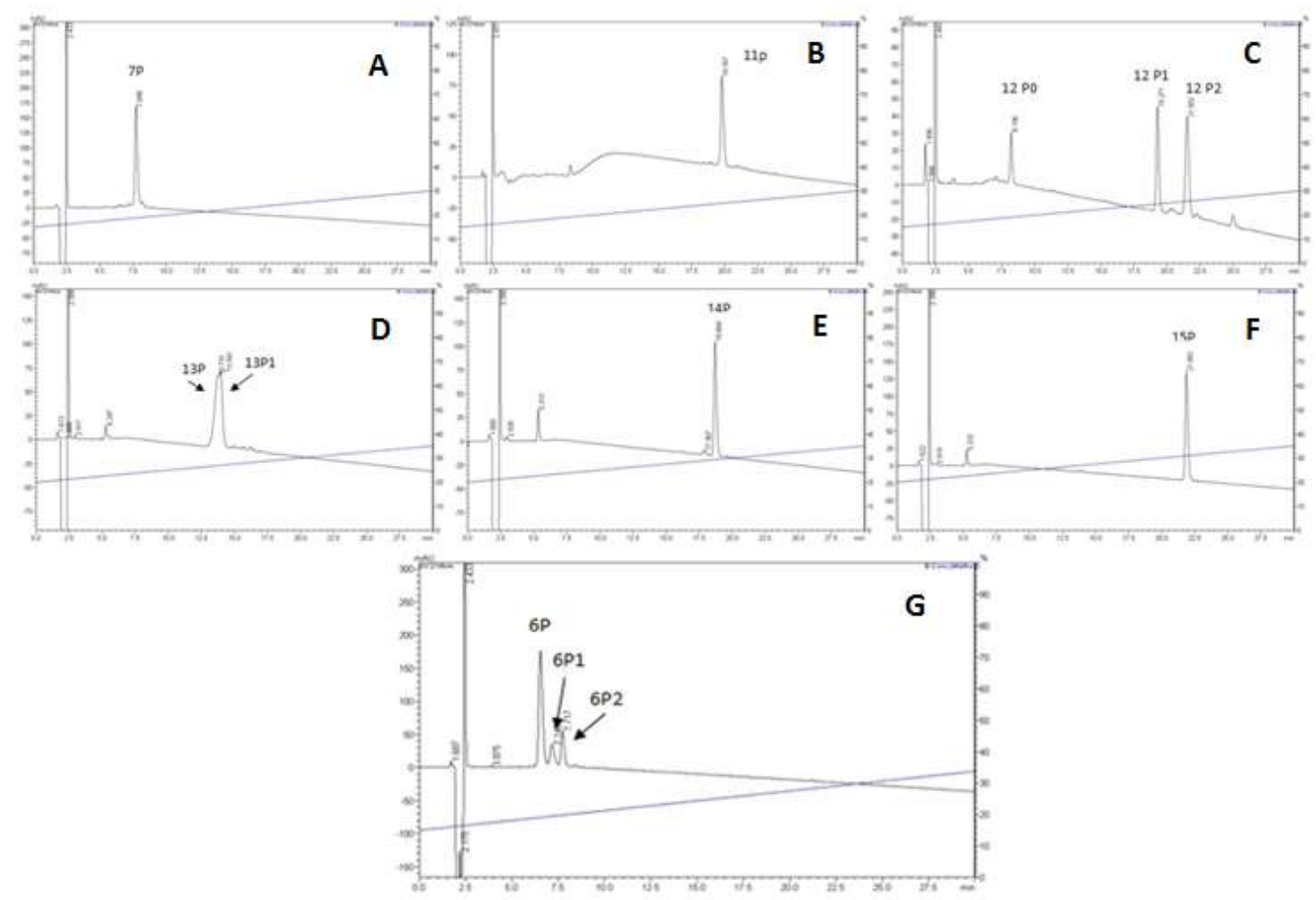

A: Fração 7, gradiente utilizado $15-30 \% \mathrm{~B} / 30 \mathrm{~min}$ (velocidade = 0,5\% de B/min.), originou um pico apenas; $\mathrm{B}$ : Fração 11, gradiente utilizado $15-30 \% \mathrm{~B} / 30 \mathrm{~min}$ (vel. = 0,5 B/min), originou um pico apenas; C: Fração 12, gradiente utilizado $15-30 \% \mathrm{~B} / 30 \mathrm{~min}(\mathrm{vel} .=0,5 \mathrm{~B} / \mathrm{min}$ ) originou três picos; D: Fração 13, gradiente utilizado 15$30 \% \mathrm{~B} / 30 \mathrm{~min}$ (vel. = 0,5 B/min), originou um pico o qual foi dividido em duas coletas; E: Fração 14, gradiente utilizado 20-35\% B/ $30 \mathrm{~min}$ (vel. = 0,5 B/min), originou um pico apenas; F: Fração 15, gradiente utilizado 20$35 \% \mathrm{~B} / 30 \mathrm{~min}$ (vel. = 0,5 B/min), originou um pico apenas; G: Fração 6, gradiente utilizado 15-40\%B/ 40 min (vel. $=0,625 \% \mathrm{~B} / \mathrm{min}$ ), originou três picos.

Figura 21 - Porcentagem de inibição das novas frações coletadas provenientes da "abertura" dos picos perante a inibição da enzima EP 24.16 selvagem

\begin{tabular}{|c|c|}
\hline Fração & EP 24.16 \\
\hline $6 \mathrm{P}$ & SI \\
\hline $6 \mathrm{P} 1$ & $100 \%$ \\
\hline $6 \mathrm{P} 2$ & $\mathrm{SI}$ \\
\hline $12 \mathrm{P}$ & $\mathrm{SI}$ \\
\hline $12 \mathrm{P} 1$ & $40 \%$ \\
\hline $12 \mathrm{P} 2$ & $40 \%$ \\
\hline $13 \mathrm{P}$ & $70 \%$ \\
\hline $13 \mathrm{P} 1$ & $70 \%$ \\
\hline
\end{tabular}

SI= Sem inibição relativa

As novas frações foram testadas perante a enzima EP 24.16 selvagem recombinante. A fração 6P1 se destacou, demonstrando um grande potencial inibitório. Estes resultados culminaram com a priorização das amostras a serem analisadas para a obtenção da sequência peptídica que as compõem. 
A fração 6P1 ganhou destaque por conta de seu grande potencial inibitório (Figura 22), sendo selecionada para a primeira análise por espectrometria de massas. A ordem determinada para as análises por espectrometria de massas foi: 6P1, 13P, 13P1, 12P, 15P, 12P1, 12P2, 11P e 14P.

Figura 22 - Inibição das amostras 6P, 6P1 e 6P2 em relação à EP 24.16 recombinante selvagem

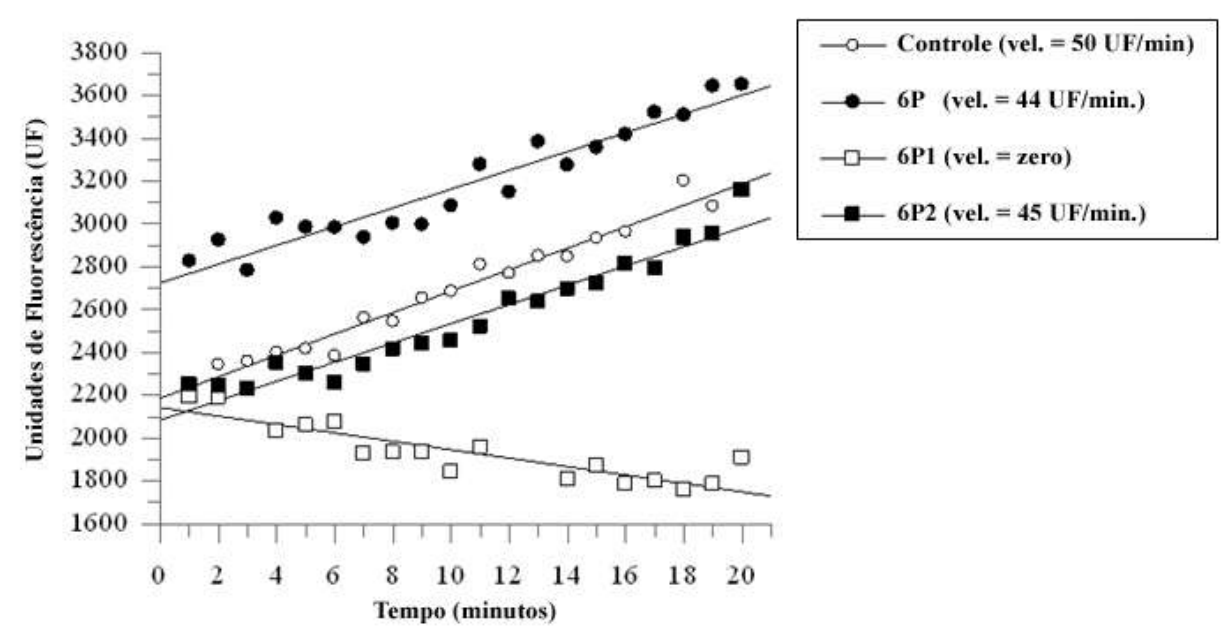

Para o ensaio, foram utilizados 7,5 ng de EP 24.16, $10 \mu \mathrm{M}$ de QFS, $2 \mu \mathrm{L}$ das soluções 6P, 6P1,6P2 e tampão PBS (pH 7,4) suficientes para $100 \mu \mathrm{L}$ de volume final. A fração 6P1 apresentou inibição acentuada da enzima, sendo selecionada para as análises por espectrometria de massas.

\subsection{Sequenciamento dos peptídeos provenientes dos experimentos com a neurolisina (EP 24.16) selvagem e cataliticamente inativa por espectrometria de massas (LC- MS/MS)}

O sequenciamento por espectrometria de massas foi realizado em colaboração com o Dr. Fabio Cesar Gozzo, do Instituto de Química da UNICAMP.

Através das análises por espectrometria de massas da fração $6 \mathrm{P} 1$, foi possível a determinação da sequência primária de três oligopeptídeos: um tripeptídeo de sequência FTR, um tetrapeptídeo de sequência YLPT (Figura 23A e 23B, respectivamente) e um pentapeptídeo de sequência KEXXG (Apêndice A), onde o aminoácido X poderia ser tanto a leucina como a isoleucina, os quais possuem mesma massa molecular (113 Da), sendo impossível determinar sua real sequência através de nossos métodos empregados durante as análises por espectrometria de massas. Através de experimentos citados no Apêndice A, a verdadeira fórmula do peptídeo KEXXG foi determinada como KEILG. 
Figura 23 - Espectro de massas dos peptídeos encontrados na fração 6P1
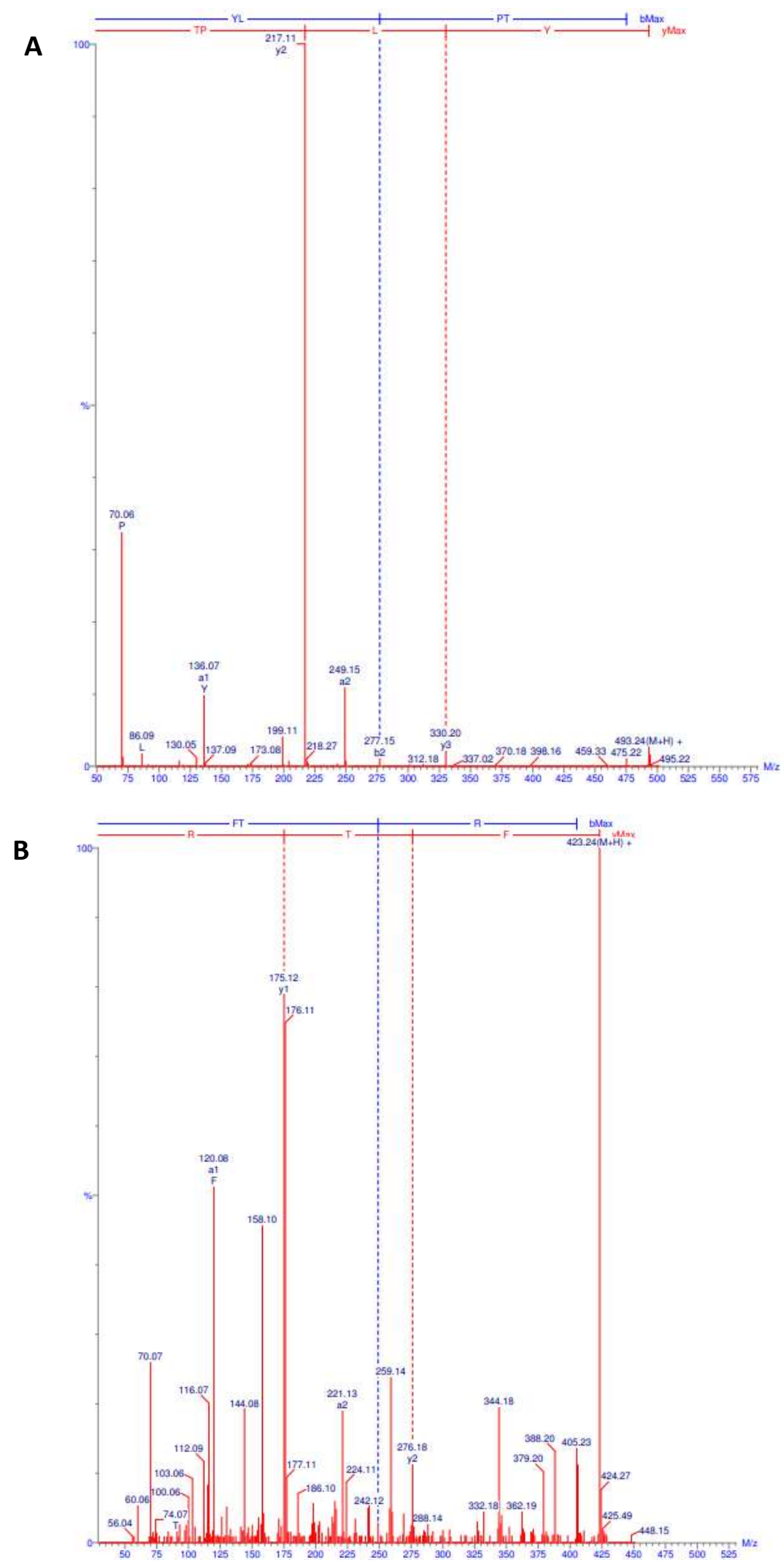

A: YLPT; B: FTR. O espectro do peptídeo KEXXG encontra-se no Apêndice A. 


\subsection{Síntese dos peptídeos}

As sequências KELLG, KEILG, YLPT e FTR foram sintetizadas com sucesso com o emprego da técnica de Atherton e Sheppard (1989).

4.6 Testes para a caracterização de substratos dentre os peptídeos sintetizados perante as enzimas timet oligopeptidase (EP 24.15), neurolisina (EP 24.16), neprilisina (EP 24.11) e enzima conversora de angiotensina ECA

Os testes envolvendo os peptídeos e as enzimas EP 24.15, EP 24.16, EP 24.11 e ECA para a determinação de possíveis substratos foram realizados em sistema HPLC. Os resultados (dados não mostrados) apontaram que as enzimas não foram capazes de clivar os peptídeos, pela ausência de novos picos no perfil cromatográfico apresentado após quatro horas de incubação a $37^{\circ} \mathrm{C}$. O controle bradicinina foi clivado durante os experimentos referentes a estas condições de incubação.

4.7 Testes para a identificação de inibidores dentre os peptídeos sintetizados perante as enzimas timet oligopeptidase (EP 24.15), neurolisina (EP 24.16), neprilisina (EP 24.11) e enzima conversora de angiotensina ECA

Os peptídeos foram testados em diferentes concentrações para a observação do potencial inibitório perante as enzimas (Figura 24). 
Figura 24 - Quadro contendo diferentes concentrações dos peptídeos e suas inibições em relação a cada enzima testada

\begin{tabular}{|c|c|c|c|c|c|}
\hline Peptídeo & $\begin{array}{c}\text { Concentração } \\
\text { peptídica }\end{array}$ & $\begin{array}{c}\text { EP } 24.15 \\
\text { \% de inibição }\end{array}$ & $\begin{array}{c}\text { EP } 24.16 \\
\text { \% de inibição }\end{array}$ & $\begin{array}{c}\text { EP } 24.11 \\
\text { \% de inibição }\end{array}$ & $\begin{array}{c}\text { ECA } \\
\% \text { de inibição }\end{array}$ \\
\hline \multirow{5}{*}{ KELLG } & $1 \mu \mathrm{M}$ & SI & SI & NT & SI \\
\hline & $5 \mu \mathrm{M}$ & $13 \%$ & SI & NT & $\mathrm{SI}$ \\
\hline & $10 \mu \mathrm{M}$ & NT & NT & NT & NT \\
\hline & $50 \mu \mathrm{M}$ & $34 \%$ & SI & NT & SI \\
\hline & $150 \mu \mathrm{M}$ & NT & NT & $11 \%$ & NT \\
\hline \multirow{5}{*}{ KEILG } & $1 \mu \mathrm{M}$ & $12 \%$ & SI & NT & SI \\
\hline & $5 \mu \mathrm{M}$ & $35 \%$ & SI & NT & SI \\
\hline & $10 \mu \mathrm{M}$ & NT & NT & NT & NT \\
\hline & $50 \mu \mathrm{M}$ & $44 \%$ & SI & NT & SI \\
\hline & $150 \mu \mathrm{M}$ & NT & NT & SI & NT \\
\hline \multirow{5}{*}{ FTR } & $1 \mu \mathrm{M}$ & SI & SI & NT & SI \\
\hline & $5 \mu \mathrm{M}$ & $8 \%$ & $15 \%$ & NT & SI \\
\hline & $10 \mu \mathrm{M}$ & NT & NT & NT & NT \\
\hline & $50 \mu \mathrm{M}$ & $50 \%$ & $19 \%$ & NT & SI \\
\hline & $150 \mu \mathrm{M}$ & NT & NT & $36 \%$ & NT \\
\hline \multirow{5}{*}{ YLPT } & $1 \mu \mathrm{M}$ & $9 \%$ & $8 \%$ & NT & SI \\
\hline & $5 \mu \mathrm{M}$ & $9 \%$ & $25 \%$ & $67 \%$ & SI \\
\hline & $10 \mu \mathrm{M}$ & NT & NT & $85 \%$ & NT \\
\hline & $50 \mu \mathrm{M}$ & $6 \%$ & $25 \%$ & NT & SI \\
\hline & $150 \mu \mathrm{M}$ & NT & NT & $97 \%$ & NT \\
\hline
\end{tabular}

NT= não testado SI= sem inibição

Os resultados representam as diferentes ações e potenciais de inibição dos peptídeos testados em relação às enzimas. Nota-se que nenhum dos peptídeos teve ação sobre a ECA

\subsection{Determinação do mecanismo e constante de inibição (Ki) dos peptídeos em relação às enzimas timet oligopeptidase (EP 24.15), neurolisina (EP 24.16) e neprilisina (EP 24.11)}

Em relação a EP 24.15, o peptídeo KELLG apresentou um Ki de $84 \mu \mathrm{M}$ e mecanismo de ação competitivo, pois este compete pela ligação com o sítio ativo com o substrato da enzima, retardando a catálise e modoficando o Km. O peptídeo KEILG apresentou um Ki de $16 \mu \mathrm{M}$ e mecanismo de ação não competitivo, pois este se liga a enzima em um local diferente do sítio ativo, alterando sua afinidade com o substrato e deste modo retardando a catálise sem modificar o Km (Apêndice A). O FTR apresentou Ki de $36 \mu \mathrm{M}$ e mecanismo competitivo e o YLPT apresentou Ki de $74 \mu \mathrm{M}$ e mecanismo competitivo.

Em relação à EP 24.16, os peptídeos KELLG e KEILG não foram capazes de inibirem a ação desta enzima, não sendo determinados o Ki e o mecanismo de ação por esta razão. $\mathrm{O}$ peptídeo FTR apresentou Ki de $36 \mu \mathrm{M}$ e mecanismo de inibição competitivo e o YLPT apresentou Ki de $120 \mu \mathrm{M}$ e mecanismo de ação competitivo. 
Sobre a EP 24.11, os peptídeos KELLG, KEILG e FTR não obtiveram dados experimentais suficientes para a determinação do Ki e mecanismo de ação de inibição enzimática. O peptídeo YLPT apresentou um Ki de 0,94 $\mu \mathrm{M}$ e um mecanismo de ação competitivo em relação a essa enzima. A relação entre os peptídeos e os mecanismos de inibição perante as enzimas podem ser observados a seguir na Figura 25.

Figura 25 - Quadro relacionando o tipo de mecanismo de inibição e Ki (constante de inibição) dos peptídeos perante as enzimas

\begin{tabular}{|c|c|c|c|c|c|}
\hline \multirow{2}{*}{ Enzima } & \multicolumn{4}{|c|}{ Peptídeos } & \multirow{2}{*}{$\begin{array}{c}\text { Mecanismo } \\
\text { de inibição }\end{array}$} \\
\hline & KELLG & KEILG & FTR & YLPT & \\
\hline \multirow{2}{*}{ EP 24.15} & $\begin{array}{c}+ \\
(\mathrm{Ki} 84 \mu \mathrm{M})\end{array}$ & - & $\begin{array}{c}+ \\
(\mathrm{Ki} 36 \mu \mathrm{M})\end{array}$ & $\begin{array}{c}+ \\
(\mathrm{Ki} 74 \mu \mathrm{M})\end{array}$ & Competitivo \\
\hline & - & $\begin{array}{c}+ \\
(\mathrm{Ki} 16 \mu \mathrm{M}) \\
\end{array}$ & - & - & Não competitivo \\
\hline \multirow[t]{2}{*}{ EP 24.16} & - & - & $\begin{array}{c}+ \\
(\mathrm{Ki} 36 \mu \mathrm{M}) \\
\end{array}$ & $\begin{array}{c}+ \\
(\mathrm{Ki} 120 \mu \mathrm{M}) \\
\end{array}$ & Competitivo \\
\hline & - & - & - & - & Não competitivo \\
\hline \multirow[t]{2}{*}{ EP 24.11} & $*$ & $*$ & $*$ & $\begin{array}{c}+ \\
(\mathrm{Ki} 0,94 \mu \mathrm{M}) \\
\end{array}$ & Competitivo \\
\hline & $*$ & $*$ & $*$ & - & Não competitivo \\
\hline
\end{tabular}

+ = positivo para o mecanismo de inibição; - = negativo para o mecanismo de ação; * = inconclusivo.

4.9 Possíveis alterações da sensibilidade dolorosa induzida por inibidores para timet oligopeptidase (EP 24.15) e neurolisina (EP 24.16) obtidos das frações de baixa massa molecular do veneno do escorpião Tityus serrulatus

\subsubsection{Ensaios de nocicepção}

Os peptídeos KELLG, KEILG e YLPT não foram capazes de acarretar antinocicepção in vivo no teste aos quais foram submetidos (Figura 26). 
Figura 26 - Limiar de dor X tempo de tratamento após o pico de ação da carragenina

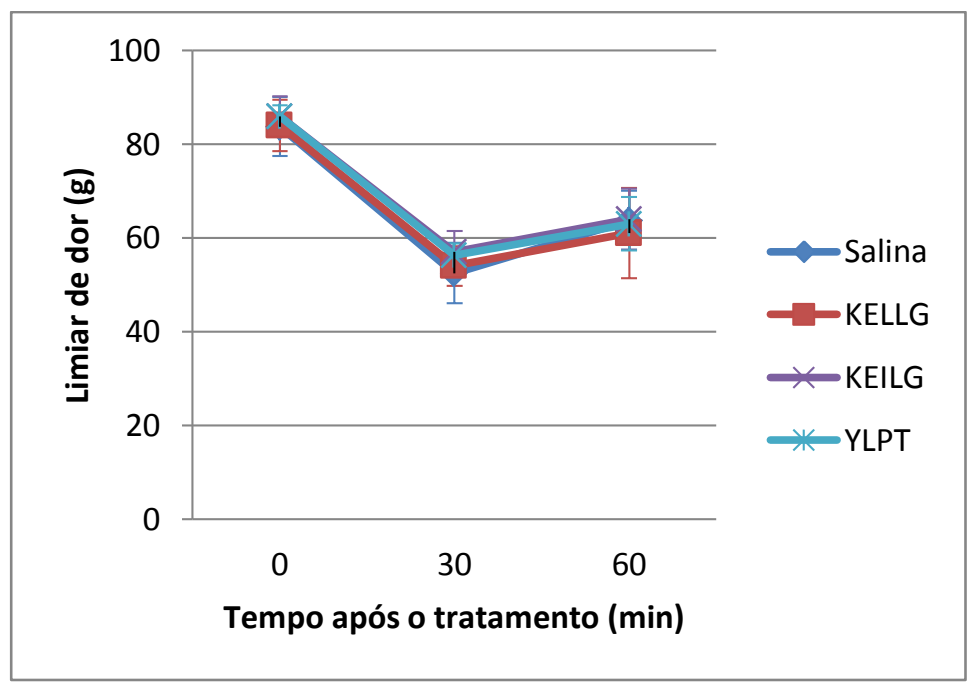

Resultado experimental após o tratamento dos animais com salina, KELLG, KEILG e YLPT. Os peptídeos foram injetados durante o pico de ação da carragenina e a pressão suportada pelo animal na pata analisada com o emprego do analgesímetro 30 e 60 minutos após injeção dos peptídeos. Os sistemas acompanharam as características do controle salina, não demonstrando efeito antinociceptivo.

Já o peptídeo FTR demonstrou capacidade de acarretar antinocicepção no modelo de hiperalgesia inflamatória, observada 30 min após sua administração (Figura 27).

Figura 27 - Injeção do peptídeo FTR com a presença da carragenina

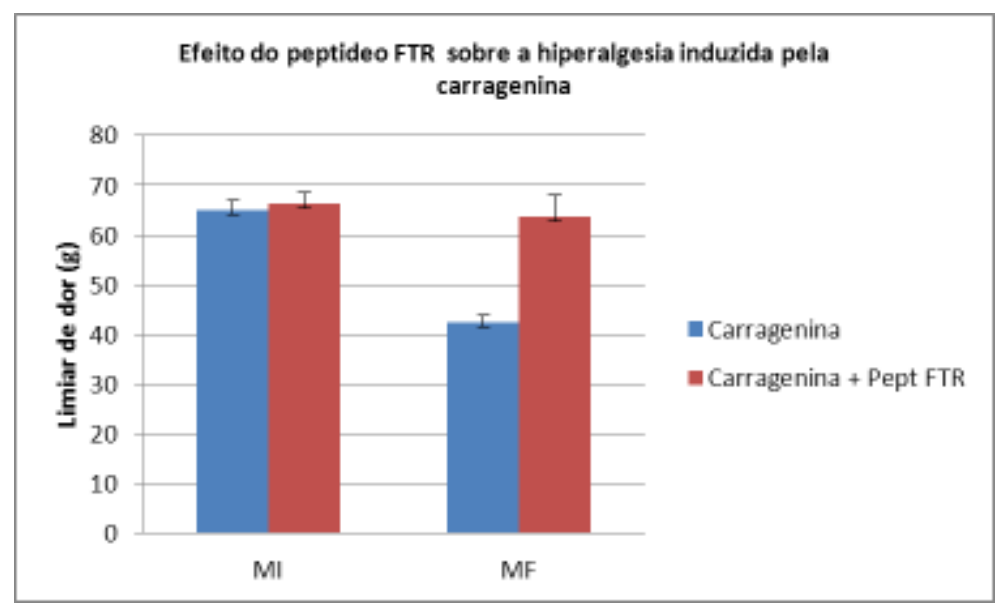

O FTR foi injetado 2 horas após a injeção da carragenina, para a observação do seu efeito no pico de ação da mesma, que é no tempo de 3 horas após injeção. Observou-se que no momento inicial (MI) o limiar de dor suportado por ambos os grupos foi similar. No momento final (MF), após uma hora do momento inicial, o peptídeo foi capaz de demonstrar uma ação antinociceptiva em relação ao controle carragenina. 
Ainda, quando avaliado na ausência de hiperalgesia, o peptídeo foi capaz de induzir aumento na sensibilidade dolorosa dos animais (Figura 28).

Figura 28 - Injeção do peptídeo FTR sem a presença da carragenina

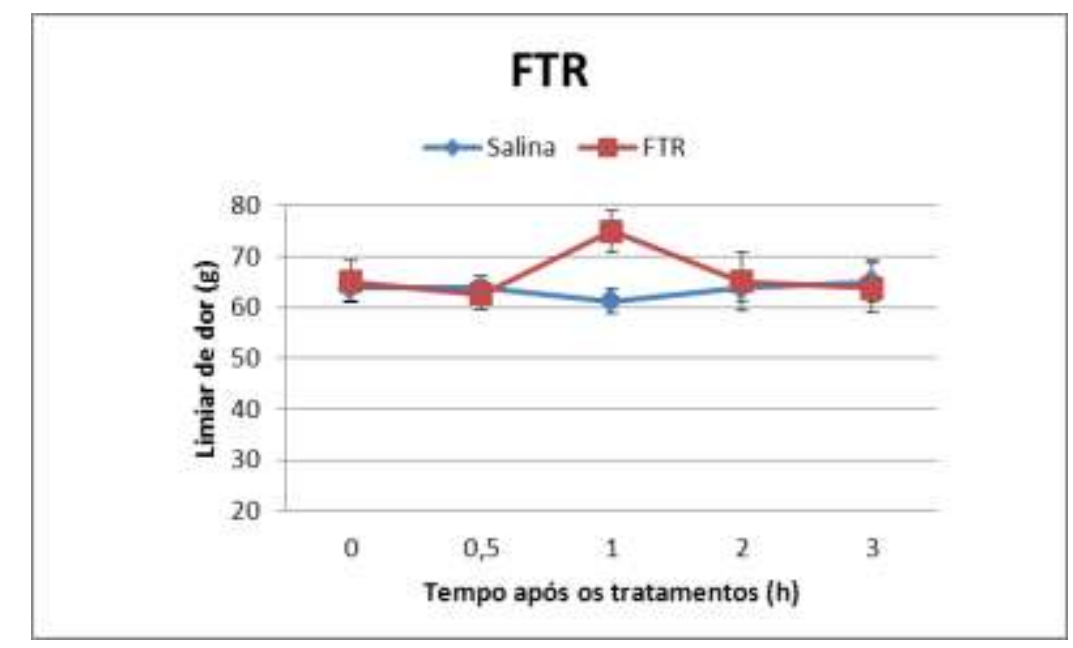

O FTR foi capaz de causar resposta antinociceptiva apenas com a sua injeção. Comparando-se como controle salina, após uma hora de injeção, o grupo FTR suportou aproximadamente $20 \mathrm{~g}$ a mais.

4.9.2 Inflamação: Reatividade vascular e alterações na interação leucócito-endotélio induzidas pelos peptídeos da peçonha do Tityus serrulatus na microcirculação do músculo cremaster de camundongos

Em relação à reatividade vascular, nenhum peptídeo foi capaz de provocar alguma resposta reativa ao estímulo.

Sobre o aumento no rolamento de leucócitos, o peptídeo KEILG foi capaz de provocar tal resposta (Figura 29). Já os peptídeos KELLG, YLPT e FTR não apresentaram aumento no rolamento (dados não mostrados). O peptídeo FTR demonstrou um fenômeno diferenciado, cessando a circulação por aproximadamente um minuto após aplicação e retomando normalmente após este período (dados não mostrados). 
Figura 29 - Relação entre o número de leucócitos em rolamento por minuto dos peptídeos KEILG e KELLG

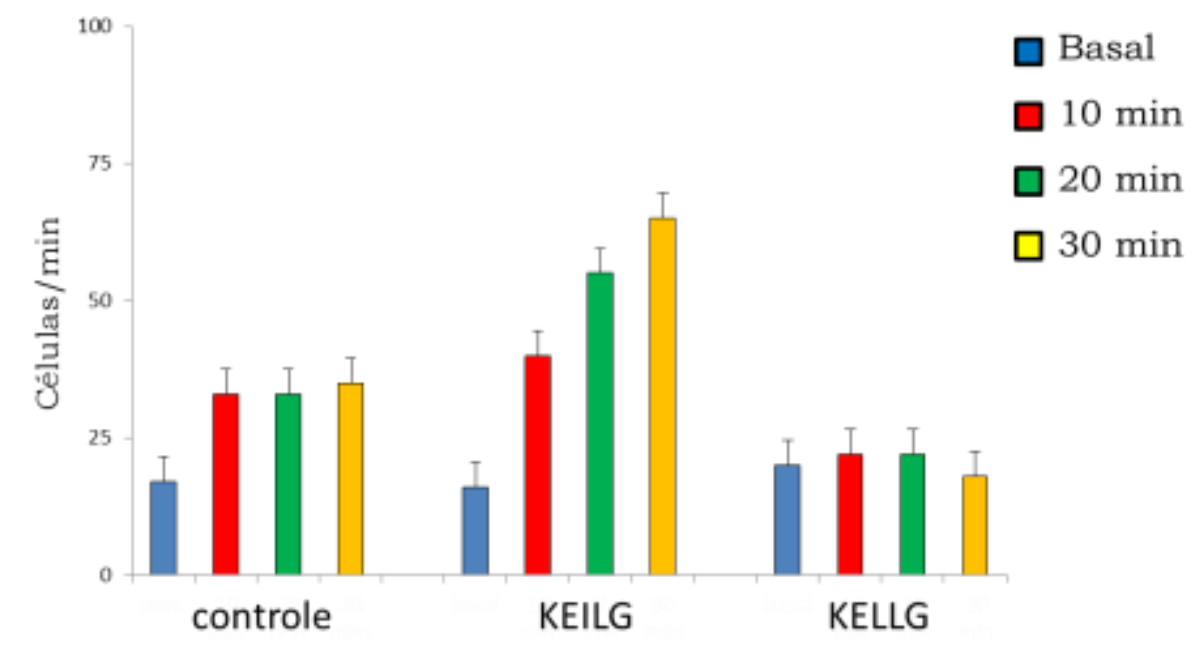

Observação do aumento do rolling de leucócitos em relação ao controle salina e o peptídeo KEILG. O peptídeo KELLG não foi capaz de acarretar aumento. As células foram contadas durante três minutos nos intervalos de 10, 20 e 30 minutos após tratamento. 


\section{DISCUSSÃO}

O emprego da técnica de captura de peptídeos através de enzimas recombinantes cataliticamente inativas já foi demonstrado como eficaz na busca e identificação de peptídeos bioativos, como é o caso da hemopressina, isolada a partir do tecido cerebral de ratos, onde dentre suas ações demonstradas está à atuação como agonista inverso de receptores canabinpoides $\mathrm{CB}_{1}$ além do efeito hipotensor (HEIMANN et al., 2007; RIOLI et al., 2003). A mesma técnica foi empregada em peçonhas de animais, onde Rioli e colaboradores (2008), conseguiram identificar alguns peptídeos já descritos e o inédito BPP-AP no veneno da Bothrops jararacussu utilizando a técnica de captura peptídica com a EP 24.15 cataliticamente inativa. Este peptídeo inédito foi capaz de causar hipotensão arterial em ratos sem causar efeitos inflamatórios, possuindo um potencial a ser explorado (RIOLI et al., 2008).

Sabendo-se que muitos peptídeos apresentam atividade biológica e que são constituintes dos venenos escorpiônicos (BATISTA et al., 2004), nosso grupo decidiu estudar o isolamento e identificação de possíveis peptídeos biologicamente ativos no veneno do escorpião Tityus serrulatus, um escorpião encontrado no Brasil e responsável pelos acidentes mais graves (FUNASA, 1998). A primeira estratégia empregada foi a tentativa de isolamento através de enzimas cataliticamente inativas por mutação sítio dirigida (RIOLI et al., 2003). As enzimas escolhidas foram a EP 24.15 e EP 24.16, que são capazes de interagirem com oligopeptídeos (OLIVEIRA et al., 2001) e apresentaram bons resultados, anteriormente descritos. Além da relação entre o tamanho dos peptídeos e a determinação das enzimas empregadas para o isolamento, foram levadas em conta algumas manifestações descritas em vítimas de casos mais graves de acidentes, como agitação psicomotora, arritmias cardíaca e respiratória, hipertensão arterial seguida de hipotensão, onde as interações com estas enzimas poderiam colaborar com a explicação de alguns destes quadros apresentados ( BATISTA et al., 2004; FREIRE-MAIA; CAMPOS, 1989) e ainda servirem como potenciais ferramentas biotecnológicas. Além disso, a opção pelo uso das enzimas EP 24.15 e EP 24.16 na fração de baixa massa molecular do veneno, e não de outras proteases, é devido ao fato dessas enzimas possuírem uma vantagem sobre outras proteases (e mesmo sobre outras proteínas) por serem altamente específicas para oligopeptídeos em decorrência de sua estrutura, que limita a entrada em seu sítio catalítico apenas de peptídeos de baixa massa molecular contendo entre 6 a 17 resíduos de aminoácidos (OLIVEIRA et al., 2001). Do ponto de vista econômico isso é importante, pois, a síntese de peptídeos menores é geralmente mais simples e menos onerosa. 
Inicialmente ocorreu a produção das enzimas recombinantes EP 24.15 e EP 24.16 selvagens e mutantes para serem empregadas nos experimentos de isolamento peptídico. As enzimas produzidas apresentaram uma banda única em SDS-PAGE, indicando a pureza das preparações. O potencial hidrolítico das enzimas selvagens foi estudado com o substrato QFS, mostrando alta atividade específica. Ao contrário, as oligopeptidases mutantes não apresentaram atividade sobre o substrato, implicando na caracterização das enzimas recombinantes em relação à natureza catalítica esperada (apresentação de atividade enzimática nas enzimas selvagens e não apresentação de atividade nas enzimas mutantes).

Após a produção, purificação, quantificação e caracterização das enzimas recombinantes, deu-se início aos experimentos de incubação da fração de baixa massa molecular da peçonha com as enzimas recombinantes cataliticamente inativas e consequentes análises dos perfis apresentados por HPLC, com o propósito de validar o emprego da técnica de captura no veneno do escorpião amarelo. De posse dos resultados, foi observado que as enzimas foram capazes de capturar alguns peptídeos que se apresentaram em frações com picos mais elevados comparativamente com o perfil cromatográfico do controle, representando a afinidade de certos peptídeos pelas enzimas empregadas, como já visto em trabalhos anteriores (RIOLI et al., 2003, 2008). As frações em destaque foram coletadas e enviadas para a análise por espectrometria de massas.

Após análises para a determinação da sequência primária dos peptídeos capturados, ocorreram problemas relacionados a quantidades insuficientes de peptídeos presentes nas amostras, não sendo possível identificá-los através dos métodos de espectrometria de massas empregados. Com este impasse, houve a idealização de experimentos capazes de sanarem este problema.

Comparando-se os perfis cromatográficos do emprego da EP 24.15 e EP 24.16 inativas, foi possível perceber que muitas das frações selecionadas tinham características em comum às duas enzimas, devido a grande semelhança estrutural entre elas, responsável pelo compartilhamento de diversos substratos e inibidores pelas mesmas (RAY et al., 2002, 2004; RIOLI et al., 1998). Por conta deste fato, houve o emprego apenas da enzima recombinante EP 24.16 cataliticamente inativa para a alteração de alguns parâmetros experimentais, objetivando a obtenção de maior concentração peptídica para possibilitar as análises por espectrometria de massas pelo método de seleção peptídica utilizado.

Relacionando esta deficiência quantitativa com a possível quantidade inicial de amostra empregada anteriormente nos experimentos, partiu-se de uma maior massa de veneno liofilizado para a obtenção da fração de baixa massa molecular. Foi realizado então o 
fracionamento a partir de $40 \mathrm{mg}$ (quatro vezes mais do que a quantidade anteriormente empregada) do veneno liofilizado. Em seguida, para conhecer a quantidade de peptídeos que seriam empregados nos experimentos, realizou-se a quantificação pelo método da fluorescamina, obtendo a concentração peptídica de 5,35 $\mu \mathrm{g} / \mu \mathrm{L}$. Sabendo-se a concentração, foi determinada que a quantidade empregada nos experimentos seria de 160,5 $\mu \mathrm{g}$ de peptídeos totais contidos em $30 \mu \mathrm{L}$ do pool utilizado.

Outro fato que poderia estar relacionado com o resultado obtido seria a de baixa concentração de enzima empregada durante o experimento de captura. Objetivando um maior número de enzimas livres com o propósito de capturar o maior número de peptídeos ligantes, foram utilizadas duas diferentes concentrações de EP 24.16 inativa (100 $\mu \mathrm{g}$ e $150 \mu \mathrm{g})$. Qualitativamente, foi observado que, mais uma vez, o experimento de captura teve êxito. $\mathrm{O}$ sistema contendo $150 \mu \mathrm{g}$ de EP 24.16 inativa foi capaz de capturar mais peptídeos do que o emprego de $100 \mu \mathrm{g}$. Porém, mesmo com o sucesso da técnica, não foi possível obter quantidades suficientes de peptídeos para a realização de análises por espectrometria de massas. Este problema pode estar relacionado com a concentração limitada de ligantes e sua relação de afinidade com a enzima no pool como um todo, considerando as perdas durante o processo de gel filtração a seco. É bem provável que por este motivo, uma quantidade bem inferior a inicial empregada é obtida após a captura, culminando nesta dificuldade enfrentada em nossos experimentos, criando um impasse sobre a funcionalidade da captura perante a quantidade final de amostra obtida em relação a sua baixa concentração na amostra inicial utilizada da fração de baixa massa molecular do veneno. Na tentativa de mais um empenho da desta abordagem, em busca de oligopeptídeos de fato capturados pelas enzimas recombinantes inativas, foi realizado um experimento envolvendo a mistura das amostras oriundas dos experimentos empregados 100 e $150 \mu \mathrm{g}$ de enzimas inativas para a realização da captura. Com esta abordagem, foi demonstrado que esta mistura culminou em amostras quantitativamente compatíveis para as análises por espectrometria de massas.

Com o mix, foi possível obter quantidade de amostra peptídica suficiente para a realização da análise por espectrometria de massas, resolvendo nosso antigo problema quantitativo. Dentre as amostras analisadas, algumas massas se destacaram e se encontram em fase de sequenciamento manual para a obtenção da estrutura peptídica primária. Porém neste trabalho não iremos explorar o potencial destas novas sequências, ficando para trabalhos futuros do grupo.

Através das massas analisadas por MS/MS, conseguimos a obtenção da sequência do peptídeo FTR pertencente à fração 4 sequenciada. 
O encontro da sequência FTR na fração 4 demonstrou que a abordagem empregada utilizando a seleção através de screening por cinética enzimática com as oligopeptidases selvagens também foi válida em nossas análises, como discutido a seguir.

Em paralelo aos experimentos com a EP 24.16 cataliticamente inativa descritos acima, iniciamos o isolamento de peptídeos contidos na peçonha, mas agora utilizando as oligopeptidases recombinantes selvagens e o substrato FRET.

Com a intenção de identificar estes peptídeos, considerando o tempo decorrente das tentativas sucedidas, uma nova estratégia foi abordada para o isolamento de peptídeos contidos na peçonha, onde a partir do pool de baixa massa molecular do veneno foi realizado o fracionamento do mesmo, seguido de coleta das frações selecionadas e a realização de um screening por atividade enzimática por FRET e as oligopeptidases selvagens (EP 24.15 e EP 24.16).

Com a determinação do perfil do pool peptídico por HPLC, quinze frações foram selecionadas para serem coletadas e testadas perante as enzimas recombinantes selvagens, objetivando a exclusão das frações que não apresentassem um potencial inibitório das mesmas.

O screening sugeriu que dentre as 15 frações coletadas, oito foram capazes de inibirem relativamente às enzimas. O termo "inibição relativa" foi empregado, pois dentre as frações analisadas, poderiam ser obtidos inibidores de fato ou então substratos. Dentre as frações, sete foram selecionadas em relação ao poder inibitório relativo perante as enzimas, para uma nova purificação em HPLC utilizando diferentes gradientes, empregados para a obtenção de uma melhor separação das amostras. Este procedimento foi denominado como "abertura" dos picos.

Após a realização das novas purificações, novas frações surgiram para serem coletadas. As novas subfrações foram testadas perante a enzima EP 24.16 recombinante selvagem, com o objetivo de excluir frações que não apresentassem poder inibitório e de priorizar as amostras a serem analisadas por espectrometria de massas.

A fração 6P1 ganhou destaque por conta de seu grande potencial inibitório, sendo selecionada para a primeira análise por espectrometria de massas, sendo um bom alvo para a procura de potenciais peptídeos componentes do veneno capazes de interagirem com as enzimas testadas. Através dos níveis de interações, foi determinada uma ordem para as análises por espectrometria de massas: $6 \mathrm{P} 1,13 \mathrm{P}, 13 \mathrm{P} 1,12 \mathrm{P}, 15 \mathrm{P}, 12 \mathrm{P} 1,12 \mathrm{P} 2,11 \mathrm{P}$ e $14 \mathrm{P}$.

Os resultados iniciais com as sequências obtidas provenientes da fração 6P1 estão de acordo com o esperado, pois o tamanho destes peptídeos relacionou-se com o tamanho das 
moléculas que interagem com as enzimas EP 24.15 e EP 24.16, as quais estão restritas, até o momento, a composição de no máximo a 17 resíduos de aminoácidos, devido à localização do sítio catalítico destas enzimas (OLIVEIRA et al., 2001; RAY et al., 2004).

Com a determinação de nossas sequências peptídicas, iniciamos uma busca por informações sobre as mesmas. O peptídeo FTR recentemente foi descrito em um trabalho de transcriptoma envolvendo o escorpião Tityus serrulatus onde esta sequência é parte de um peptídeo antimicrobiano pertencente à família dos AMPs (antimicrobial peptides) (ALVARENGA et al., 2012).

O peptídeo YLPT, apresentou um resultado muito interessante, pois sua sequência é encontrada no peptídeo denominado Proctolin (RYLPT), com o diferencial de não possuir a arginina em sua fração N-terminal, desta forma, sendo denominado por nós como "desArgProctolin”. O Proctolin foi o primeiro neuropeptídeo sequenciado de insetos e que possui atividade biológica responsável pelo controle de vários aspectos da vida dos mesmos. Esse peptídeo é responsável pela estimulação da contração de músculos viscerais e esqueléticos além de aumentar a frequência cárdica de alguns insetos (ORCHARD et al., 1989). Desta maneira, a sequência encontrada no veneno do escorpião amarelo pode estar envolvida na ação sobre suas presas, podendo estar relacionada com o desequilíbrio homeostático de insetos e êxito em suas caçadas. Como este peptídeo faz parte da sequência de um neuropeptídio de insetos, talvez o mesmo pudesse agir sobre a neprilisina (EP 24.11), responsável pela degradação de alguns neuropetídeos (ROQUES et al., 1993; BARRETT et al., 1998).

Os levantamentos realizados com a sequência KEXXG nos demonstraram que a ordem de aminoácidos KEXLG era conservada na espécie Tityus, pois a leucina mais próxima do C-terminal era encontrada em outras sequências, desta maneira nos direcionando a síntese de dois peptídeos: KELLG e KEILG. Em nossas consultas, o peptídeo KELLG está presente na sequência da encefalina (JONES et al., 1982). A encefalina é responsável pelo controle da nocicepção do corpo, atuando como ligantes de receptores opióides, sendo um peptídeo opióide endógeno (NODA et al., 1982). Porém, nossos resultados indicaram que o pentapeptídeo naturalmente encontrado no veneno é KEILG. Os detalhes sobre a pesquisa envolvendo a determinação da sequência do peptídeo KEILG pode ser vista no Apêndice A.

Com a obtenção dos peptídeos sintéticos puros, houve o início dos experimentos in vitro. O primeiro a ser realizado foi com o intuito de encontrar substratos para as enzimas EP 24.15, EP 24.16, EP 24.11 e ECA, dentre os peptídeos isolados do veneno do escorpião amarelo. Os resultados demonstraram que nenhuma das enzimas foi capaz de hidrolisar as 
sequências peptídicas testadas, consequentemente, estes não se comportaram como substratos destas enzimas no tempo de incubação empregado. Este resultado se apresentou de maneira interessante, pois demonstra a resistência destes peptídeos perante a algumas enzimas de mamíferos, sendo o contrário indesejado, uma vez que um dos objetivos deste projeto é a busca de inibidores enzimáticos. Outro fato que pode estar relacionado a este resultado é a importância para o escorpião de moléculas que resistam a ataques de peptidases, desta maneira mantendo sua constituição original para obter êxito em sua captura/defesa. Com este resultado, prosseguimos para testes de cinética enzimática de inibição para as mesmas enzimas.

Com o emprego de substratos fluorescentes específicos, foram determinados quais peptídeos atuavam como moduladores da atividade enzimática das enzimas testadas.

Diante dos dados apresentados, nenhum dos peptídeos estudados foi capaz de inibir a ação da ECA na concentração máxima testada de $50 \mu \mathrm{M}$, desta forma descartando-os como possíveis inibidores terapêuticos que tenham como alvo esta enzima. Por outro lado, a conservação da atividade da ECA que é responsável por converter a angiotensina I em angiotensina II (SKEGGS et al., 1976), um potente vasoconstritor e consequente agente hipertensor, pode ter algum fundamento, pois a conservação desta enzima pelos componentes do veneno pode favorecer o quadro de hipertensão arterial apresentado pelos acidentados e que são desfavoráveis às vitimas do escorpião T. serrulatus.

Em relação às enzimas EP 24.15 e EP 24.16, ocorreu um resultado muito interessante envolvendo os peptídeos KELLG e KEILG. Sabe-se que as duas enzimas são bem similares, apresentando $60 \%$ de homologia e por este motivo, apresentam muitos ligantes em comum (DAUCH et al., 1995). Ray e colaboradores (2004) apresentaram em seu trabalho a cristalografia da EP 24.15, revelando sua estrutura, que comparada a da EP 24.16, confirmava a similaridade destas duas enzimas. Ambas apresentam um sítio catalítico profundo, justificando o fato de terem como alvos apenas oligopeptídeos capazes de penetrarem no sítio catalítico. Por conta destas semelhanças, a busca por inibidores específicos, capazes de diferenciá-las, sempre foi um alvo de estudos, pois ambas compartilham muitos inibidores com alguma diferença relacionada ao $\mathrm{K}_{\mathrm{i}}$ (OLIVEIRA et al., 2001). Portanto, descrevemos um pentapeptídeo oriundo da peçonha de um escorpião e outro análogo que são capazes de selecioná-las perante a inibição apenas da EP 24.15, podendo contribuir para futuros estudos que poderão revelar as sutis diferenças destas enzimas em relação a funções específicas. Com estes mesmos peptídeos também foi possível determinar a importância de uma sequência 
correta e que mudanças mínimas em um aminoácido podem ter grandes consequências. Este fato foi abordado no Apêndice A.

Os peptídeos FTR e YLPT apresentaram uma inibição moderada destas enzimas. Com estes resultados, é importante salientar que as técnicas utilizadas para o isolamento dos peptídeos trabalhados estão de acordo, pois os mesmos interagem com as enzimas testadas. A forte inibição relacionada à fração isolada "6P1" pode ser explicada pela sinergia de seus componentes em relação à modulação cinética da enzima. É importante notar que os peptídeos sequenciados foram selecionados por conta do sinal apresentado no espectro de massas, existindo a possibilidade da presença de peptídeos não sequenciados e que demonstrem atividade relacionada à modulação das enzimas testadas.

Sobre os resultados em relação à EP 24.11, obtidos inicialmente através de um screening empregando $150 \mu \mathrm{M}$ de cada uma das sequências sintéticas, dois peptídeos foram capazes de inibir esta enzima: FTR e YLPT. O FTR não teve seu $\mathrm{K}_{\mathrm{i}}$ calculado, por conta das grandes quantidades que seriam necessárias de uma amostra escassa que apresentou $36 \%$ de inibição da enzima com $150 \mu \mathrm{M}$. Portanto, o YLPT, que apresentou uma potente inibição de 97\% com o emprego de $150 \mu \mathrm{M}$ teve seu $\mathrm{K}_{\mathrm{i}}$ calculado e seu mecanismo de inibição competitivo determinado $(\mathrm{Ki}=0,94 \mu \mathrm{M})$. A EP 24.11 possui como principais substratos in vivo os hormônios natriuréticos (ANP e BNP), as endotelinas, como também a angiotensina I convertida em angiotensina (1-7), a bradicinina e a substância P (BARRETT et al., 1998). Portanto, a busca por inibidores está relacionada com a procura de alvos terapêuticos em relação à regulação da pressão arterial e analgesia (ROQUES et al., 1993). Deste modo, a molécula YLPT isolada do veneno do $T$. serrulatus pode ser candidata a um protótipo terapêtico envolvendo a EP 24.11 como alvo, uma vez que pode estar relacionada à analgesia ou agente hipotensor em testes in vivo. Claro que devemos considerar toda a complexidade de um organismo vivo, mas os resultados apresentados não descartam esta possibilidade, podendo ainda ser parte de uma explicação sobre o quadro de hipotensão apresentado durante os acidentes causados pelo escorpião. E por fim, mais um fato importante a ser destacado é em relação à presença de uma proteína neprilysin-like encontrada na vespa Venturia canescens, podendo o YLPT atuar nesta enzima nas presas do T. serrulatus. Desta maneira, possuindo um possível potencial biotecnológico em relação à inseticidas (ASGARI et al., 2002).

Para mensurarmos os potenciais inibitórios e caracterizarmos os tipos de mecanismos de ação apresentados, foi feito o gráfico de Lineweaver-Burk e calculado o Ki dos inibidores de acordo com o mecanismo apresentado. 
Encontramos um pouco de dificuldade para a determinação dos valores de inibição do YLPT em relação à EP 24.11, por conta da potência apresentada pelo inibidor. Conseguimos a resolução deste problema empregando o método descrito no trabalho de Cornish-Bowden (1974).

O principal interesse para a exploração da atividade biológica in vivo dos peptídeos isolados estava relacionado com experimentos envolvendo dor, inflamação e reatividade vascular. Estes experimentos foram selecionados por conta do quadro apresentado pelos acidentados, relatando dor local e desencadeamento de um processo inflamatório (FREIREMAIA; CAMPOS, 1989; FUNASA, 1998), juntamente coma a participação das enzimas empregadas nos estudos do projeto nestes sistemas (AYALA, 1990; CARDOZO; ORLOWSKI, 1993; GOMEZ et al., 2011; MOLINEAUX; KEST et al., 1992; ORLOWSKI et al., 1983; TELFORD et al., 1995), com o objetivo de avaliar uma possível função dos peptídeos isolados do veneno e também um potencial biotecnológico, em caso de resposta farmacológica.

Inicialmente, em colaboração com a Dra. Gisele Picolo, testamos os peptídeos YLPT, KELLG e KEILG para a avaliação da atividade antinociceptiva em ratos, onde observamos os efeitos dos peptídeos em relação à antinocicepção no pico de ação da carragenina, substância utilizada para indução de hiperalgesía. Nenhum dos peptídeos foi capaz de apresentar uma ação antinociceptiva na dose testada de $20 \mu \mathrm{g}$.

A expectativa deste experimento ficou relacionada ao peptídeo YLPT ter um potencial analgésico, por conta dos resultados apresentados in vitro em relação à inibição da EP 24.11 (neprilisina), pois a mesma é responsável pela degradação da encefalina, um analgésico opióide endógeno, muitas vezes liberado em situações de stress (KÖNIG et al., 1996; ROQUES et al., 1993, 2012;). A inibição da EP 24.11 é um sistema que vem sendo explorado buscando por novas drogas analgésicas (EBERLIN et al., 2012; KHAKET et al., 2012). Porém, esta ação analgésica é mais evidenciada no sistema nervoso central, caso não observado e avaliado em nossos experimentos, ficando por conta da elaboração de procedimentos mais específicos para a avaliação deste possível efeito, como visto, por exemplo, no experimento realizado pelo grupo de Lecomte (1986), onde houve a administração endovenosa de Acetorfan, um pró-fármaco lipofílico do Tiorfan, um potente inibidor da EP 24.11, causando efeito duradouro da antinocicepção após a administração endovenosa de D-Ala ${ }^{2}$-Met-encefalina, que é um substrato da neprilisina.

Portanto, localmente este peptídeo não foi capaz de causar efeito antinociceptivo, visto que o mesmo provavelmente não consegue ultrapassar a barreira hematoencefálica para 
a observação de seus efeitos perante a inibição da EP 24.11 em relação à analgesia (EBERLIN et al., 2012). Além disso, foi observado que este efeito é dependente da concentração de encefalina endógena (ROQUES et al., 1993, 2012). Foram realizados testes similares para a avaliação da capacidade dos peptídeos induzirem dor, com a injeção dos mesmos e avaliação da resposta sem a presença da carragenina. Os peptídeos não foram capazes de induzirem efeito nociceptivo. Novamente, porém com uma outra abordagem, a expectativa ficou por conta do peptídeo YLPT, tentando relacionar o papel da EP 24.11 na degradação da substância $\mathrm{P}$, um neurotransmissor capaz de modular a sensibilidade da dor (FELIPE, DE et al., 1998), e com isso o possível resultado esperado seria ação nociceptiva local, porém nada foi observado referente a este efeito.

O peptídeo FTR foi surpreendente em seus resultados. Por si só ele foi capaz de apresentar uma resposta antinociceptiva em relação ao controle salina sem a indução de hiperalgesia. No teste envolvendo a carragenina e indução de hiperalgesia, onde ele foi aplicado 2 horas após a carragenina para se observar o efeito no pico de ação da mesma, também foi capaz de exercer ação antinociceptiva em relação ao controle constituído por salina. Por conta das fracas inibições de nossas enzimas testadas pela ação do FTR, o efeito antinociceptivo obtido não deve estar relacionado a elas. Para entendimento dos mecanismos de ação, novos experimentos deverão ser realizados em projetos futuros. O resultado tem importância em relação ao efeito obtido, demonstrando mais uma vez que moléculas selecionadas pelas interações de oligopeptidases se apresentam com atividade biológica, assim como demonstrado em alguns outros trabalhos (RIOLI et al., 2003, 2008). Já foi descrito na literatura um peptídeo derivado do escorpião Buthus martensi Karch com 64 aminoácidos, capaz de apresentar efeitos analgésicos (CAO et al., 2004). Porém, o FTR, mesmo necessitando de mais estudos, já apresenta uma vantagem de ser constituído de uma molécula bem menor de apenas três aminoácidos, sendo de síntese mais facilitada e menos onerosa.

Seguindo com os experimentos in vivo, os peptídeos foram testados em relação à reatividade vascular e rolling de leucócitos na microcirculação do músculo cremaster em camundongos, com a colaboração do Dr. Luís Roberto de Camargo Gonçalves.

Na literatura se pode observar a capacidade das toxinas da peçonha do T. serrulatus induzirem efeitos inflamatórios, como por exemplo, as toxinas Ts6 e Ts2 (ZOCCAL et al., 2013). Portanto, verificamos nos experimentos que o oligopeptídeo KEILG, de apenas cinco aminoácidos, foi capaz de apresentar um aumento gradual do rolling dos leucócitos em um intervalo de trinta minutos experimentais, com isso, a participação deste peptídeo sugere a 
contribuição para o desencadeamento de uma resposta que pode ser inflamatória, salientando a importância de uma pequena molécula em relação aos quadros de envenenamento. Os peptídeos KELLG e YLPT não apresentaram um aumento no rolling dos leucócitos comparados ao controle salina (dados não mostrados). Mais uma vez ficou demonstrado que a diferença de um aminoácido, mesmo isômero, na fórmula de um oligopeptídeo acarreta diferentes respostas em relação à atividade biológica e como a identificação do real constituinte da peçonha do escorpião é de extrema importância para o estudo do comportamento da molécula (Apêndice A). Estudos relacionados ao peptídeo FTR apresentaram um fenômeno diferenciado. Durante as aplicações tópicas no músculo cremaster, observou-se uma paralização momentânea da circulação por aproximadamente um minuto. Após este período, a circulação era retomada a condições normais sem aparentes modificações relacionados ao calibre dos vasos (dados não mostrados). Mais estudos deverão ser realizados envolvendo o peptídeo FTR para o entendimento deste fenômeno apresentado e sua ligação, ou não, com o efeito antinociceptivo apresentado. Uma hipótese levantada através da observação deste fenômeno está em uma possível ativação plaquetária local, a qual estaria colaborando com o efeito antinociceptivo apresentado, pois já foi demonstrado na literatura que a diminuição de plaquetas colabora com uma resposta antinociceptiva, como por exemplo, no trabalho realizado por Yamashita e colaboradores (2011), onde a indução da diminuição plaquetária circulante demonstrou uma resposta antinociceptiva em relação a hiperalgesia causada pelo emprego de carragenina e do veneno da Bothrops jararaca em ratos.

Em relação aos estudos anteriores envolvendo espectrometria de massas das frações selecionadas anteriormente por screening envolvendo atividade enzimática, conseguimos uma nova sequência primária de um peptídeo localizado na fração 13P: LLSAF. Novamente, no estudo relacionado ao transcriptoma do T. serrulatus este peptídeo aparece como parte da sequência de um AMP (peptídeo antimicrobiano) na conformação LISAF (leucinaisoleucina- serina- alanina- fenilalanina) (ALVARENGA et al., 2012). Deste modo, baseados nesta sequência descrita, resolvemos manter a primeira leucina e variar a segunda leucina da sequência com a isoleucina para a realização da síntese deste peptídeo em duas sequências primárias: LLSAF e LISAF. A síntese se encontra em andamento, porém certamente as análises envolvendo esta nova sequência ficarão para trabalhos futuros. 


\section{CONCLUSÕES}

Através dos estudos realizados, foi possível o isolamento, a partir da fração de baixa massa molecular do veneno do T. serrulatus, de três oligopeptídeos: YLPT, FTR, KEILG além de seu análogo KELLG. Foi demonstrado que esses peptídeos foram capazes de interagir com as enzimas EP 24.15 e EP 24.16, cumprindo a proposta inicial do trabalho. Sobre estes resultados apresentados, o mais relevante foi em relação ao peptídeo KEILG, capaz de interagir apenas com a EP 24.15. Além disso, estes peptídeos foram testados perante a ECA, porém sem interações, e perante EP 24.11, onde o peptídeo YLPT se destacou como inibidor.

Sobre os testes in vivo relacionados à nocicepção, os peptídeos KEILG, KELG e YLPT não foram capazes de exercerem quaisquer respostas. Já o peptídeos FTR, de apenas 3 aminoácidos, foi capaz de exercer resposta antinociceptiva com e sem indução de hiperalgesia.

Em relação a testes envolvendo o rolamento de leucócitos, o peptídeo KEILG demonstrou um potencial de aumento dos mesmos, destacando a importância de oligopeptídeos na composição da peçonha do escorpião amarelo sendo que mais estudos serão necessários para a determinação de ação pró-inflamatória ou não. O peptídeo FTR demonstrou um fenômeno relacionado à paralização momentânea da microcirculação, onde mais estudos deverão ser realizados para esclarecimentos e para entender se há ou não ligação com o efeito antinociceptivo apresentado.

Novas massas foram obtidas através do emprego da técnica de captura peptídica por utilização de enzimas cataliticamente inativas e serão analisadas em projetos futuros.

Por fim, é importante salientar a importância da interação e integração interdisciplinar com as colaborações para o avanço científico e como estes resultados poderão contribuir para o desenvolvimento de projetos futuros. 


\section{REFERÊNCIAS*}

ALMAAYTAH, A.; ALBALAS, Q. Scorpion venom peptides with no disulfide bridges: A review. Peptides, v. 51, p. 35-45, 2014.

ALVARENGA, É. R. et al. Transcriptome analysis of the Tityus serrulatus scorpion venom gland. Open Journal of Genetics, v. 2, p. 210-220, 2012.

AMARAL, C. F.; REZENDE, N. A. DE; FREIRE-MAIA, L. Acute pulmonary edema after Tityus serrulatus scorpion sting in children. The American Journal of Cardiology, v. 71, n. 2, p. 242-245, 1993.

ARAUJO, M. C. et al. Internally quenched fluorogenic substrates for angiotensin I-converting enzyme. Journal of Hypertension, v. 17, n. 5, p. 665-672, 1999.

ASGARI, S.; REINEKE, A.; BECK, M.; SCHMIDT, O. Isolation and characterization of a neprilysin-like protein from Venturia canescens virus-like particles. Insect Molecular Biology, v. 11, n. 5, p. 477-485, 2002.

ATHERTON, E.; SHEPPARD, R. C. Solid phase peptide synthesis: a practical approach. 1989.

BAEZ, S. An open cremaster muscle preparation for the study of blood vessels by in vivo microscopy. Microvascular Research, v. 5, n. 3, p. 384-394, 1973.

BARRETT, A. J. et al. Thimet oligopeptidase and oligopeptidase M or neurolysin. Methods in Enzymology, v. 248, p. 529-556, 1995.

BARRETT, A. J.; RAWLINGS, N. D.; WOESSNER, J. F. Handbook of proteolytic enzymes. Academic Press New York, 1998.

BARROS, N. M. T. et al. Neprilysin carboxydipeptidase specificity studies and improvement in its detection with fluorescence energy transfer peptides. Biological Chemistry, v. 388, n. 4, p. 447-455, 2007.

BATISTA, C. V. F. et al. Proteomic analysis of the venom from the scorpion Tityus stigmurus: biochemical and physiological comparison with other Tityus species. Comparative Biochemistry and Physiology. Toxicology \& Pharmacology : CBP, v. 146, n. 1-2, p. 147-157, 2007.

BATISTA, C. V. F. et al. Proteomic analysis of Tityus discrepans scorpion venom and amino acid sequence of novel toxins. Proteomics, v. 6, n. 12, p. 3718-3727, 2006.

BATISTA, C. V. F. et al. Proteomics of the venom from the Amazonian scorpion Tityus cambridgei and the role of prolines on mass spectrometry analysis of toxins. Journal of

\footnotetext{
* De acordo com

ASSOCIAÇÃO BRASILEIRA DE NORMAS TÉCNICAS. NBR 6023: informação e documentação: referências: elaboração. Rio de

Janeiro, 2002
} 
chromatography. B, Analytical Technologies in the Biomedical and Llife Sciences, v. 803, n. 1, p. 55-66, 2004.

BECERRIL, B.; MARANGONI, S.; POSSANI, L. D. Toxins and genes isolated from scorpions of the genus Tityus. Toxicon : official Journal of the International Society on Toxinology, v. 35, n. 6, p. 821-835, 1997.

BERTI, D. A. et al. Analysis of intracellular substrates and products of thimet oligopeptidase in human embryonic kidney 293 cells. The Journal of Biological Chemistry, v. 284, n. 21, p. 14105-14116, 2009.

BOMFIM, J. H. G. G.; GODOY, M. A. F. DE; GIGLIO, J. R.; OLIVEIRA, A. M. DE; ARANTES, E. C. Effects induced by Tityus serrulatus scorpion venom and its toxins TsTX-I and TsTX-V on the rat isolated retractor penis muscle. Pharmacology, v. 73, n. 4, p. 190$198,2005$.

BORTOLUZZI, L. R.; QUEROL, M. V. M.; QUEROL, E. Notes on the occurrence of Tityus serrulatus Lutz \& Mello, 1922 (Scorpiones, Buthidae) in the Western areas of Rio Grande do Sul, Brazil. Biota Neotropical, v. 7, n. 3, p. 357-359, 2007.

BRADFORD, M. M. A rapid and sensitive method for the quantitation of microgram quantities of protein utilizing the principle of protein-dye binding. Analytical Biochemistry, v. 72, p. 248-254, 1976.

BRASIL. Ministério da Saúde. Sistema de Informação de Agravos de Notificação Notificação de acidentes por animais peçonhentos. Acesso: http://dtr2004.saude.gov.br/sinanweb/tabnet/dh?sinan/animaisp/bases/animaisbr.def jun 2013.

BROWN, C. K. et al. Structure of neurolysin reveals a deep channel that limits substrate access. Proceedings of the National Academy of Sciences of the United States of America, v. 98, n. 6, p. 3127-3132, 2001.

CAO, Z.-Y. et al. Purification and characterization of a new peptide with analgesic effect from the scorpion Buthus martensi Karch. The Journal of Peptide Research : official Journal of the American Peptide Society, v. 64, n. 1, p. 33-41, 2004.

CARDOSO, J. L. C. et al. Animais peçonhentos no Brasil: biologia, clínica e terapêutica dos acidentes. 2 ed. São Paulo: Sarvier, 2009.

CARDOZO, C.; ORLOWSKI, M. Evidence that enzymatic conversion of N-[1(R,S)-carboxy3-phenylpropyl]-Ala-Ala-Phe-p-aminobenzoate, a specific inhibitor of endopeptidase 24.15, to $\mathrm{N}-[1(\mathrm{R}, \mathrm{S})$-carboxy-3-phenylpropyl]-Ala-Ala is necessary for inhibition of angiotensin converting enzyme. Peptides, v. 14, n. 6, p. 1259-1262, 1993.

CARMONA, A. K.; JULIANO, M. A.; JULIANO, L. The use of Fluorescence Resonance Energy Transfer (FRET) peptides for measurement of clinically important proteolytic enzymes. Anais da Academia Brasileira de Ciências, v. 81, n. 3, p. 381-92, 2009.

CATTERALL, W. A. et al. Voltage-gated ion channels and gating modifier toxins. Toxicon : official Journal of the International Society on Toxinology, v. 49, n. 2, p. 124-141, 2007. 
CESTÈLE, S.; CATTERALL, W. A. Molecular mechanisms of neurotoxin action on voltagegated sodium channels. Biochimie, v. 82, n. 9, p. 883-892, 2000.

CHU, T. G.; ORLOWSKI, M. Soluble metalloendopeptidase from rat brain: action on enkephalin-containing peptides and other bioactive peptides. Endocrinology, v. 116, n. 4, p. $1418-1425,1985$.

CLEMENTE, G. .; TEIXEIRA, M. .; FREIRE-MAIA, L.; ROSSONI, R. . Mechanisms underlying the structural alterations of the rat submandibular gland induced by Tityus serrulatus tityustoxin. Toxicon, v. 40, n. 6, p. 731-738, 2002.

CORNISH-BOWDEN, A. A simple graphical method for determining the inhibition constants of mixed, uncompetitive and non-competitive inhibitors. The Biochemical Journal, v. 137, n. 1, p. 143-154, 1974.

CORRÊA, M. M. et al. Biochemical and histopathological alterations induced in rats by Tityus serrulatus scorpion venom and its major neurotoxin tityustoxin-I. Toxicon, v. 35, n. 7 , p. 1053-1067, 1997.

CUNHA, F. et al. Intracellular peptides as natural regulators of cell signaling. The Journal of Biological Chemistry, v. 283, n. 36, p. 24448-24459, 2008.

CUPO, P.; JURCA, M.; AZEVEDO-MARQUES, M. M.; OLIVEIRA, J. S. M.; HERING, S. E. Severe scorpion envenomation in Brazil: Clinical, laboratory and anatomopathological aspects. Revista do Instituto de Medicina Tropical de São Paulo, v. 36, n. 1, p. 67-76, 1994.

DAS, M.; HARTLEY, J. L.; SOFFERS, R. L. Serum angiotensin-converting enzyme. Isolation and relationship to the pulmonary enzyme. The Journal of Biological Chemistry, v. 252, n. 4, p. 1316-1319, 1977.

DAUCH, P.; VINCENT, J. P.; CHECLER, F. Molecular cloning and expression of rat brain endopeptidase 3.4.24.16. The Journal of Biological Chemistry, v. 270, n. 45, p. 2726627271, 1995.

EBERLIN, M.; MÜCK, T.; MICHEL, M. C. A comprehensive review of the pharmacodynamics, pharmacokinetics, and clinical effects of the neutral endopeptidase inhibitor racecadotril. Frontiers in Pharmacology, v. 3, p. 93, 2012.

EL-HENNAWY, H. Scorpions in Ancient Egypt. Euscorpius, n. 119, 2011.

FELIPE, C. DE; et al. Altered nociception, analgesia and aggression in mice lacking the receptor for substance P. Nature, v. 392, n. 6674, p. 394-397, 1998.

FERREIRA, L. A.; ALVES, E. W.; HENRIQUES, O. B. Peptide T, a novel bradykinin potentiator isolated from Tityus serrulatus scorpion venom. Toxicon : official Journal of the International Society on Toxinology, v. 31, n. 8, p. 941-947, 1993.

FONTENELE-NETO, J. D.; MASSARELLI, E. E.; GURGEL GARRIDO, P. A.; BEAUDET, A.; FERRO, E. S. Comparative fine structural distribution of endopeptidase 24.15 
(EC3.4.24.15) and 24.16 (EC3.4.24.16) in rat brain. The Journal of Comparative Neurology, v. 438, n. 4, p. 399-410, 2001.

FREIRE-MAIA, L.; CAMPOS, J. A. Pathophysiology and treatment of scorpion poisoning. Natural Toxins, Pergamon Press, Oxford, p. 139-159, 1989.

FREITAS, J. C. DE. Nomenclature in toxinology: relations with the chemical communication between organisms and biological properties of toxins. Mem. Inst. Butantan, v. 53, n. 2, p. 191-195, 1991.

FUNASA. Manual de Diagnóstico e Tratamento de Acidentes por Animais Peçonhentos. Brasília: Fundação Nacional de Saúde, 1998.

GOMEZ, R. et al. Metallopeptidase inhibition potentiates bradykinin-induced hyperalgesia. Pain, v. 152, n. 7, p. 1548-1554, 2011.

GUPTA, S. DAS et al. Indian black scorpion (Heterometrus bengalensis Koch) venom induced antiproliferative and apoptogenic activity against human leukemic cell lines U937 and K562. Leukemia Research, v. 31, n. 6, p. 817-825, 2007.

HEIMANN, A. S. et al. Hemopressin is an inverse agonist of CB1 cannabinoid receptors. Proceedings of the National Academy of Sciences of the United States of America, v. 104, n. 51, p. 20588-20593, 2007.

HMED, B.; SERRIA, H. T.; MOUNIR, Z. K. Scorpion peptides: potential use for new drug development. Journal of Toxicology, v. 2013, p. 958797, 2013.

IWATA, N. et al. Metabolic regulation of brain Abeta by neprilysin. Science (New York, N.Y.), v. 292, n. 5521, p. 1550-1552, 2001.

JOHNSON, G. D.; AHN, K. Development of an internally quenched fluorescent substrate selective for endothelin-converting enzyme-1. Analytical Biochemistry, v. 286, n. 1, p. 112$118,2000$.

JONAS, P.; VOGEL, W.; ARANTES, E. C.; GIGLIO, J. R. Toxin of the scorpion Tityus serrulatus modifies both activation and inactivation of sodium permeability of nerve membrane. Pflugers Archiv European Journal of Physiology, v. 407, n. 1, p. 92-99, 1986.

JONES, B. N.; SHIVELY, J. E.; KILPATRICK, D. L.; KOJIMA, K.; UDENFRIEND, S. Enkephalin biosynthetic pathway: a 5300-dalton adrenal polypeptide that terminates at its $\mathrm{COOH}$ end with the sequence [Met]enkephalin-Arg-Gly-Leu-COOH. Proceedings of the National Academy of Sciences of the United States of America, v. 79, n. 4, p. 1313-1315, 1982.

KEST, B.; ORLOWSKI, M.; BODNAR, R. J. Endopeptidase 24.15 inhibition and opioid antinociception. Psychopharmacology, v. 106, n. 3, p. 408-416, 1992.

KHAKET, T. P.; SINGH, J.; ATTRI, P.; DHANDA, S. Enkephalin degrading enzymes: metalloproteases with high potential for drug development. Current Pharmaceutical Design, v. 18, n. 2, p. 220-230, 2012. 
KIM, S. I. et al. Novel roles of neuropeptide processing enzymes: EC3.4.24.15 in the neurome. Journal of Neuroscience Research, v. 74, n. 3, p. 456-467, 2003.

KIRSCH, G. E.; SKATTEBOL, A.; POSSANI, L. D.; BROWN, A. M. Modification of Na channel gating by an alpha scorpion toxin from Tityus serrulatus. The Journal of General Physiology, v. 93, n. 1, p. 67-83, 1989.

KÖNIG, M. et al. Pain responses, anxiety and aggression in mice deficient in preproenkephalin. Nature, v. 383, n. 6600, p. 535-538, 1996.

LECOMTE, J.M., COSTENTIN, J., VLAICULESCU, A., CHAILlET, P., MARCAISCOLLADO H., LLORENS-CORTES, C., LEBOYER, M., SCHWARTZ, J.C. Pharmacological properties of acetorphan, a parenterally active "enkephalinase" inhibitor. J. Pharmacol. Exp. Ther., v. 237, n. 3, p. 937-944, 1986.

LEGROS, C.; OUGHUIDENI, R.; DARBON, H.; et al. Characterization of a new peptide from Tityus serrulatus scorpion venom which is a ligand of the apamin-binding site. FEBS letters, v. 390, n. 1, p. 81-84, 1996.

LEW, R. A. et al. Substrate specificity differences between recombinant rat testes endopeptidase EC 3.4.24.15 and the native brain enzyme. Biochemical and Biophysical Research Communications, v. 209, n. 3, p. 788-795, 1995.

LI, C.; HERSH, L. B. Neprilysin: assay methods, purification, and characterization. Methods in Enzymology, v. 248, p. 253-263, 1995.

LINARDI, A.; PANUNTO, P. C.; FERRO, E. S.; HYSLOP, S. Peptidase activities in rats treated chronically with N(omega)-nitro-L-arginine methyl ester (L-NAME). Biochemical Pharmacology, v. 68, n. 2, p. 205-214, 2004.

LIRA-DA-SILVA, R. M.; AMORIM, A. M. DE; CARVALHO, F. M.; BRAZIL, T. K. ACIDENTES POR ESCORPIÃO NA CIDADE DO SALVADOR, BAHIA, BRASIL (19822000). Gazeta Médica da Bahia, v. 79, n. 1, 2009.

LOURENÇO, W. R. Parthenogenesis in scorpions: some history - new data. Journal of Venomous Animals and Toxins including Tropical Diseases, v. 14, n. 1, p. 19-44, 2008.

LOURENÇO, W. R. et al. Escorpiões de importância médica. CARDOSO JLC et al. Animais Peçonhentos no Brasil. Biologia, Clínica e Terapêutica dos Acidentes. SARVIER, São Paulo, 2003.

MAMELAK, A. N.; JACOBY, D. B. Targeted delivery of antitumoral therapy to glioma and other malignancies with synthetic chlorotoxin (TM-601). Expert Opinion on Drug Delivery, v. 4, n. 2, p. 175-186, 2007.

MARCUSSI, S. et al. Escorpiões: Biologia, Envenenamento e Mecanismos de Ação de Suas Toxinas. Ribeirão Preto: FUNPEC, 2011. 
MARTIN-EAUCLAIRE, M. F. et al. Biochemical, pharmacological and genomic characterisation of Ts IV, an $\alpha$-toxin from the venom of the South American scorpion Tityus serrulatus. FEBS Letters, 1994.

MASSARELLI, E. E. et al. Differential subcellular distribution of neurolysin (EC 3.4.24.16) and thimet oligopeptidase (EC 3.4.24.15) in the rat brain. Brain Research, v. 851, n. 1-2, p. 261-265, 1999.

MATOS, I. M. DE; ROCHA, O. A.; LEITE, R.; FREIRE-MAIA, L. Lung oedema induced by Tityus serrulatus scorpion venom in the rat. Comparative biochemistry and physiology. Part C, Pharmacology, Toxicology \& Endocrinology, v. 118, n. 2, p. 143-148, 1997.

MCKIE, N.; DANDO, P. M.; RAWLINGS, N. D.; BARRETT, A. J. Thimet oligopeptidase: similarity to "soluble angiotensin II-binding protein" and some corrections to the published amino acid sequence of the rat testis enzyme. The Biochemical Journal, v. 295, p. 57-60, 1993.

MOLINEAUX, C. J.; AYALA, J. M. An inhibitor of endopeptidase-24.15 blocks the degradation of intraventricularly administered dynorphins. Journal of Neurochemistry, v. 55, n. 2, p. 611-618, 1990.

NATESH, R.; SCHWAGER, S. L. U.; EVANS, H. R.; STURROCK, E. D.; ACHARYA, K. R. Structural details on the binding of antihypertensive drugs captopril and enalaprilat to human testicular angiotensin I-converting enzyme. Biochemistry, v. 43, n. 27, p. 8718-8724, 2004.

NEURATH, H. Proteolytic enzymes, past and future. Proceedings of the National Academy of Sciences, v. 96, n. 20, p. 10962-10963, 1999.

NODA, M. et al. Isolation and structural organization of the human preproenkephalin gene. Nature, v. 297, n. 5865, p. 431-434, 1982.

NOVELLO, J. C. et al. TsTX-IV, a short chain four-disulfide-bridged neurotoxin from Tityus serrulatus venom which acts on $\mathrm{Ca}^{2+}$-activated $\mathrm{K}^{+}$channels. Toxicon, v. 37, n. 4, p. 651660, 1999.

OLIVEIRA, V. et al. Selective neurotensin-derived internally quenched fluorogenic substrates for neurolysin (EC 3.4.24.16): comparison with thimet oligopeptidase (EC 3.4.24.15) and neprilysin (EC 3.4.24.11). Analytical Biochemistry, v. 292, n. 2, p. 257-265, 2001.

ONDETTI, M. A.; RUBIN, B.; CUSHMAN, D. W. Design of specific inhibitors of angiotensin-converting enzyme: new class of orally active antihypertensive agents. Science (New York, N.Y.), v. 196, n. 4288, p. 441-444, 1977.

ORCHARD, I.; BELANGER, J. H.; LANGE, A. B. Proctolin: a review with emphasis on insects. Journal of Neurobiology, v. 20, n. 5, p. 470-496, 1989.

ORLOWSKI, M.; MICHAUD, C.; CHU, T. G. A soluble metalloendopeptidase from rat brain. Purification of the enzyme and determination of specificity with synthetic and natural peptides. European Journal of Biochemistry / FEBS, v. 135, n. 1, p. 81-88, 1983. 
PATCHETT, A. A. et al. A new class of angiotensin-converting enzyme inhibitors. Nature, v. 288, n. 5788, p. 280-283, 1980.

PIEROTTI, A. R.; LASDUN, A.; AYALA, J. M.; ROBERTS, J. L.; MOLINEAUX, C. J. Endopeptidase-24.15 in rat hypothalamic/pituitary/gonadal axis. Molecular and Cellular Endocrinology, v. 76, n. 1-3, p. 95-103, 1991.

PIMENTA, A. M. C. et al. Novel structural class of four disulfide-bridged peptides from Tityus serrulatus venom. Biochemical and Biophysical Research Communications, v. 301, n. 4, p. 1086-1092, 2003a.

PIMENTA, A. M. C.; MARCO ALMEIDA, F. DE; LIMA, M. E. DE; MARTINEAUCLAIRE, M. F.; BOUGIS, P. E. Individual variability in Tityus serrulatus (Scorpiones, Buthidae) venom elicited by matrix-assisted laser desorption/ionization time-of-flight mass spectrometry. Rapid Communications in Mass Spectrometry: RCM, v. 17, n. 5, p. 413418, $2003 b$.

PIMENTA, A. M.; STÖCKLIN, R.; FAVREAU, P.; BOUGIS, P. E.; MARTINEAUCLAIRE, M. F. Moving pieces in a proteomic puzzle: mass fingerprinting of toxic fractions from the venom of Tityus serrulatus (Scorpiones, Buthidae). Rapid Communications in Mass Spectrometry: RCM, v. 15, n. 17, p. 1562-1572, 2001.

POLIS, G. A. The biology of Scorpions. Stanford University Press, 1990.

PORTARO, F. C. et al. Thimet oligopeptidase and the stability of MHC class I epitopes in macrophage cytosol. Biochemical and Biophysical Research Communications, v. 255, n. 3, p. 596-601, 1999.

POSSANI, L. D.; ALAGÓN, A. C.; FLETCHER, P. L.; ERICKSON, B. W. Purification and properties of mammalian toxins from the venom of the Brazilian scorpion Tityus serrulatus Lutz and Mello. Archives of Biochemistry and Biophysics, v. 180, n. 2, p. 394-403, 1977.

POSSANI, L. D.; BECERRIL, B.; DELEPIERRE, M.; TYTGAT, J. Scorpion toxins specific for $\mathrm{Na}^{+}$-channels. European Journal of Biochemistry, v. 264, n. 2, p. 287-300, 1999.

RANDALL, L. O.; SELITTO, J. J. A method for measurement of analgesic activity on inflamed tissue. Archives Internationales de Pharmacodynamie et de Thérapie, v. 111, n. 4, p. 409-419, 1957.

RAWLINGS, N. D.; TOLLE, D. P.; BARRETT, A. J. MEROPS: the peptidase database. Nucleic Acids Research, v. 32, n. Database issue, p. D160-D164, 2004.

RAY, K.; HINES, C. S.; COLL-RODRIGUEZ, J.; RODGERS, D. W. Crystal structure of human thimet oligopeptidase provides insight into substrate recognition, regulation, and localization. The Journal of Biological Chemistry, v. 279, n. 19, p. 20480-92048, 2004.

RAY, K.; HINES, C. S.; RODGERS, D. W. Mapping sequence differences between thimet oligopeptidase and neurolysin implicates key residues in substrate recognition. Protein science : a publication of the Protein Society, v. 11, n. 9, p. 2237-2246, 2002. 
REVElO, M. P.; BAMBIRRA, E. A.; FERREIRA, A. P.; DINIZ, C. R.; CHÁVEZOLÓRTEGUI, C. Body distribution of Tityus serrulatus scorpion venom in mice and effects of scorpion antivenom. Toxicon: official journal of the International Society on Toxinology, v. 34, n. 10, p. 1119-1125, 1996.

RIOLI, V.; et al. A novel bradykinin potentiating peptide isolated from Bothrops jararacussu venom using catallytically inactive oligopeptidase EP24.15. The FEBS Journal, v. 275, n. 10, p. 2442-2454, 2008.

RIOLI, V. et al. Novel natural peptide substrates for endopeptidase 24.15, neurolysin, and angiotensin-converting enzyme. The Journal of Biological Chemistry, v. 278, n. 10, p. 8547-8555, 2003.

RIOLI, V.; et al. Neuropeptide specificity and inhibition of recombinant isoforms of the endopeptidase 3.4.24.16 family: comparison with the related recombinant endopeptidase 3.4.24.15. Biochemical and Biophysical Research Communications, v. 250, n. 1, p. 5-11, 1998.

ROGOWSKI, R. S.; KRUEGER, B. K.; COLLINS, J. H.; BLAUSTEIN, M. P. Tityustoxin K alpha blocks voltage-gated noninactivating $\mathrm{K}+$ channels and unblocks inactivating $\mathrm{K}+$ channels blocked by alpha-dendrotoxin in synaptosomes. Proceedings of the National Academy of Sciences, v. 91, n. 4, p. 1475-1479, 1994.

ROQUES, B. P.; FOURNIÉ-ZALUSKI, M.-C.; WURM, M. Inhibiting the breakdown of endogenous opioids and cannabinoids to alleviate pain. Nature Reviews. Drug Discovery, v. 11, n. 4, p. 292-310, 2012.

ROQUES, B. P.; NOBLE, F.; DAUGÉ, V.; FOURNIÉ-ZALUSKI, M. C.; BEAUMONT, A. Neutral endopeptidase 24.11: structure, inhibition, and experimental and clinical pharmacology. Pharmacological Reviews, v. 45, n. 1, p. 87-146, 1993.

SAMPAIO, S. et al. Isolation of toxin TsTX-VI from Tityus serrulatus scorpion venom. Effects on the release of neurotransmitters from synaptosomes. IUBMB Life, v. 39, n. 4, p. 729-740, 1996.

SAMPAIO, S. V; ARANTES, E. C.; PRADO, W. A.; RICCIOPPO NETO, F.; GIGLIO, J. R. Further characterization of toxins T1IV (TsTX-III) and T2IV from Tityus serrulatus scorpion venom. Toxicon : official journal of the International Society on Toxinology, v. 29, n. 6, p. 663-672, 1991.

SANDOVAL, M. R. L.; LEBRUN, I. TsTx toxin isolated from Tityus serrulatus scorpion venom induces spontaneous recurrent seizures and mossy fiber sprouting. Epilepsia, v. 44, n. 7, p. 904-911, 2003a.

SANDOVAL, M. R. L.; LEBRUN, I. TSII toxin isolated from Tityus serrulatus scorpion venom: behavioral, electroencephalographic, and histopathologic studies. Brain Research Bulletin, v. 62, n. 2, p. 165-172, 2003 b. 
SARIC, T.; GRAEF, C. I.; GOLDBERG, A. L. Pathway for degradation of peptides generated by proteasomes: a key role for thimet oligopeptidase and other metallopeptidases. The Journal of Biological Chemistry, v. 279, n. 45, p. 46723-46732, 2004.

SEGEL, I. H. Enzyme Kinetics. New York: Wiley, p. 100-159, 1975.

SHRIMPTON, C. N. et al. Thiol activation of endopeptidase EC 3.4.24.15. A novel mechanism for the regulation of catalytic activity. The Journal of Biological Chemistry, v. 272, n. 28, p. 17395-17399, 1997.

SHRIMPTON, C. N.; SMITH, A. I.; LEW, R. A. Soluble metalloendopeptidases and neuroendocrine signaling. Endocrine Reviews, v. 23, n. 5, p. 647-664, 2002.

SILVA, C. L.; PORTARO, F. C.; BONATO, V. L.; CAMARGO, A. C. DE; FERRO, E. S. Thimet oligopeptidase (EC 3.4.24.15), a novel protein on the route of MHC class I antigen presentation. Biochemical and Biophysical Research Communications, v. 255, n. 3, p. 591-595, 1999.

SILVA, T. F.; CASAIS-E-SILVA, L. L.; LIRA-DA-SILVA, R. M. Avaliação da DL50 e edema pulmonar induzido pelo veneno de Tityus serrulatus (Scorpiones; Buthidae) procedente da Bahia, Brasil. Biota Neotropical, v. 5, n. 1a, p. 221-224, 2005.

SKEGGS, L. T.; DORER, F. E.; KAHN, J. R.; LENTZ, K. E.; LEVINE, M. The biochemistry of the renin-angiotensin system and its role in hypertension. The American Journal of Medicine, v. 60, n. 6, p. 737-748, 1976.

SKEGGS, L. T.; KAHN, J. R.; SHUMWAY, N. P. The preparation and function of the hypertensin-converting enzyme. The Journal of Experimental Medicine, v. 103, n. 3, p. 295-299, 1956.

SKIDGEL, R. A.; ENGELBRECHT, S.; JOHNSON, A. R.; ERDÖS, E. G. Hydrolysis of substance $\mathrm{p}$ and neurotensin by converting enzyme and neutral endopeptidase. Peptides, v. 5, n. 4, p. 769-776, 1984.

SKIDGEL, R.A.; ERDOS, E.G. Novel activity of human angiotensin I converting enzyme: release of the $\mathrm{NH} 2$ and $\mathrm{COOH}$ terminal tripeptides from the luteinizing hormone releasing hormone. Proc. Natl. Acad. Sci. USA, v. 82, p. 1025-1029, 1985.

SKIDGEL, R. A.; ERDÖS, E. G. The broad substrate specificity of human angiotensin I converting enzyme. Clinical and Experimental Hypertension. Part A, Theory and Practice, v. 9, n. 2-3, p. 243-259, 1987.

TELFORD, S. E. et al. Role of angiotensin converting enzyme in the vascular effects of an endopeptidase 24.15 inhibitor. British Journal of Pharmacology, v. 114, n. 6, p. 1185-1192, 1995.

VASCONCELOS, F. et al. Effects of voltage-gated $\mathrm{Na}^{+}$channel toxins from Tityus serrulatus venom on rat arterial blood pressure and plasma catecholamines. Comparative Biochemistry and Physiology Part C: Toxicology \& Pharmacology, v. 141, n. 1, p. 85-92, 2005. 
VERANO-BRAGA, T. et al. Moving pieces in a venomic puzzle: unveiling posttranslationally modified toxins from Tityus serrulatus. Journal of Proteome Research, v. 12, n. 7, p. 3460-3470, 2013.

VERANO-BRAGA, T. et al. Tityus serrulatus Hypotensins: a new family of peptides from scorpion venom. Biochemical and Biophysical Research Communications, v. 371, n. 3, p. 515-520, 2008.

WANG, C. et al. A novel short-chain peptide BmKX from the Chinese scorpion Buthus martensi Karsch, sequencing, gene cloning and structure determination. Toxicon : official journal of the International Society on Toxinology, v. 45, n. 3, p. 309-319, 2005.

WERKMAN, T. R.; GUSTAFSON, T. A.; ROGOWSKI, R. S.; BLAUSTEIN, M. P.; ROGAWSKI, M. A. Tityustoxin-K alpha, a structurally novel and highly potent $\mathrm{K}+$ channel peptide toxin, interacts with the alpha-dendrotoxin binding site on the cloned Kv1. $2 \mathrm{~K}+$ channel. Molecular pharmacology, v. 44, n. 2, p. 430-436, 1993.

WU, T. J. et al. Endopeptidase EC 3.4.24.15 presence in the rat median eminence and hypophysial portal blood and its modulation of the luteinizing hormone surge. Journal of Neuroendocrinology, v. 9, n. 11, p. 813-822, 1997.

YAMAJI, N. et al. Solution structure of IsTX. A male scorpion toxin from Opisthacanthus madagascariensis (Ischnuridae). European Journal of Biochemistry / FEBS, v. 271, n. 19, p. 3855-3864, 2004.

YAMASHITA, K. M. et al. Involvement of circulating platelets on the hyperalgesic response evoked by carrageenan and Bothrops jararaca snake venom. Journal of Thrombosis and Haemostasis: JTH, v. 9, n. 10, p. 2057-2066, 2011.

YANG, H. Y. T.; ERDÖS, E. G.; LEVIN, Y. A dipeptidyl carboxypeptidase that converts angiotensin I and inactivates bradykinin. Biochimica et Biophysica Acta (BBA) - Protein Structure, 1970.

YORK, I. A. et al. The cytosolic endopeptidase, thimet oligopeptidase, destroys antigenic peptides and limits the extent of MHC class I antigen presentation. Immunity, v. 18, n. 3, p. 429-440, 2003.

ZOCCAL, K. F. et al. Ts6 and Ts2 from Tityus serrulatus venom induce inflammation by mechanisms dependent on lipid mediators and cytokine production. Toxicon: official journal of the International Society on Toxinology, v. 61, p. 1-10, 2013. 


\section{APÊNDICE A}

Insights into scorpion venom peptides: alternative processing of $\beta$-KTx propeptide from Tityus serrulatus venom results in a new naturally occurring thimet oligopeptidase inhibitor 


\title{
Insights into scorpion venom peptides: Alternative processing of $\beta$-KTx propeptide from Tityus serrulatus venom results in a new naturally occurring thimet oligopeptidase inhibitor
}

\author{
Daniela Cajado Carvalho ${ }^{\mathrm{a}, 1}$, Bruno Duzzi ${ }^{\mathrm{b}, 1}$, Alexandre Kazuo Kuniyoshi ${ }^{\mathrm{a}}$, Mariana Fioramonte ${ }^{\mathrm{c}}$, \\ Fábio Cesar Gozzoc ${ }^{\text {, Robson L. Melo }}{ }^{\mathrm{b}}$, Denise Vilarinho Tambourgi ${ }^{\mathrm{a}}$, Vanessa Rioli ${ }^{\mathrm{b}}$, \\ Fernanda Calheta Portaro ${ }^{\mathrm{a}, *}$ \\ a Immunochemistry Laboratory, Butantan Institute, São Paulo, Brazil \\ b Special Laboratory of Applied Toxinology, Instituto Butantan, Av. Vital Brazil 1500, 05503-900 São Paulo, Brazil

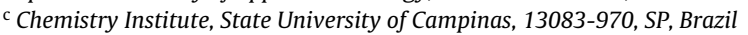

\section{A R T I C L E I N F O}

\section{Article history:}

Received 13 November 2012

Received in revised form

30 November 2012

Accepted 30 November 2012

Available online 8 December 2012

\begin{abstract}
A B S T R A C T
Most functions attributed to Tityus serrulatus venom (TsV) are related to active molecules on ion-channels; however, here we describe a new pentapeptide that was discovered through enzymatic assay selection using EP24.15. The primary structure analysis revealed the sequence KEXXG (X means Ile or Leu), similar to the sequence present in the $\beta$-KTX propeptide described from the venom of Tityus spp. We confirmed through HPLC analysis that KEILG is the peptide present in TsV, but that KELLG also inhibits EP24.15 although through different mechanisms.
\end{abstract}

(C) 2012 Elsevier Inc. All rights reserved.

\section{Introduction}

Since 2007, scorpionism is the major cause of human envenomation by animals in Brazil, surpassing accidents with snakes and spiders [4]. Most of the critical clinical cases are attributed to Tityus serrulatus scorpions, result of its wide proliferation in the urban centers and in the potential of its venom to induce severe clinical manifestations, being even fatal among children and elders. T. serrulatus venom (TsV) contains neurotoxins capable of interacting with the nervous system via ion channels and, because of that, research studies focus on neurotoxins descriptions and their mechanisms of action. Moreover, the presence of other compounds such as hyaluronidases, peptidases and biologically active peptides in TsV are poorly explored [6].

Animal venoms are a rich source of bioactive peptides due the large number and diversity of venomous species, and it is estimated that more than 40 million toxins may exist but only $0.01 \%$ were identified [15]. Furthermore, it is known that small peptides are poorly explored because of difficulties in their isolation and characterization, and also because, frequently, small peptides are represented in very low concentrations in the venom of arthropods [14]. Fortunately, the identification of molecules using mass

\footnotetext{
* Corresponding author. Tel.: +55 113726 7222; fax: +55 1137267222 .

E-mail address: fcvportaro@butantan.gov.br (F.C. Portaro).

1 These authors contributed equally to this research study.
}

spectrometry analysis is helping to characterize these neglected molecules and change the current scenario [14,15].

Through natural selection, scorpion venoms molecules were conserved to act upon certain physiological mechanisms which are shared by a great variety of organisms, including human beings. Therefore, it is probable that compounds like scorpion venom peptides can be prototypes for the development of new drugs. For example, the chlorotoxin (CTX) from the scorpion Leiurus quinquestriatus was first described as a chloride toxin [8], but nowadays it has been shown to be effective against the human glioma brain tumor via inhibition of the MMP-2, an important metallopeptidase over-expressed by tumor cells [22]. This fact suggests that novelties are still to be discovered, including new functions for already known molecules.

Thimet oligopeptidase (EP24.15) belongs to the M3 family metallopeptidase [13] and was first described as a neuropeptidedegrading enzyme present in the soluble fraction of brain homogenates [12]. The EP24.15 does not have a clear primary specificity to cleave substrates, with the ability to accommodate different amino acid residues at subsites S4 to S3' [11]. In fact, EP24.15 shows substrate size restriction to peptides containing from 5 to 17 amino acids because of its catalytic center, located in a deep channel [17]. These features of EP24.15 were decisive in successfully describing two new peptides: the human hemopressin [19] and a potent inhibitor of ACE in the venom of Bothrops jararacussu [20]. Considering the property of EP24.15 to select small molecules and its presence in the nervous system, where the TsV 
mainly acts, the objective of this study was to find in TsV new bioactive peptides selected by interaction with EP24.15 activity in vitro.

\section{Material and methods}

\subsection{Peptide Pool preparation and initial fractionation}

The lyophilized TsV, provided by Butantan Institute, São Paulo, Brazil, was suspended in sodium acetate $\mathrm{pH} 4.0$ and immediately fractionated at $4{ }^{\circ} \mathrm{C}$ using a $10 \mathrm{kDa}$ molecular weight cut off membrane (Millipore), in order to prevent proteolytic cleavage of peptides by the crude venom. The filtrated solution (Peptide Pool) was subjected to reverse phase HPLC (Prominence, Shimadzu), using a Shim-pack VP-ODS C-18 column $(4.6 \times 150 \mathrm{~mm}) ; 0.1 \%$ TFA in water (solvent $A$ ), and acetonitrile plus solvent $A(9: 1)$ as solvent $B$. The chromatography was performed at a flow rate of $1 \mathrm{~mL} / \mathrm{min}$ and detected by ultraviolet absorption $(214 \mathrm{~nm})$. The peaks were collected manually, dried and subjected to enzymatic assays.

\subsection{EP24.15 enzymatic activity screening}

The recombinant EP24.15 was obtained as described [18]. The peptidase assay was conducted in a $50 \mathrm{mM}$ phosphate and $20 \mathrm{mM}$ $\mathrm{NaCl} 7.4 \mathrm{pH}$ buffer containing $\beta$-mercaptoethanol $(1 \mathrm{mM})$ and the substrate QFS $(10 \mu \mathrm{M})$, in a final volume of $100 \mu \mathrm{L}$. The reactions occurred at $37^{\circ} \mathrm{C}$ and were initiated by the addition of EP24.15 ( $7.5 \mathrm{ng}$ ), being monitored ( $\lambda_{\mathrm{EM}} 420 \mathrm{~nm}$ and $\lambda_{\mathrm{EX}} 320 \mathrm{~nm}$ ) in a spectrofluorophotometer (Victor $3^{\mathrm{TM}}$ Perkin-Elmer), as described [20]. The results were obtained in triplicate.

\subsection{Peptide isolation and mass spectrometry analysis}

The single peptide fraction containing inhibitory peptides was purified sequentially in the RP-HPLC system described above, but with a slower gradient $(1.25 \% \mathrm{~B} / \mathrm{min})$, until reaching the pure peptide, and then subjected to mass spectrometric analyses. The peptide was analyzed by LC-MS/MS on a Synapt G1 mass spectrometer (Waters Co.). The peptide was resuspended in water and 2-5 $\mu \mathrm{L}$ injected onto a Symmetry C18 trapping column $(180 \mu \mathrm{m} \times 20 \mathrm{~mm}$, Waters). The sample was desalted for $15 \mathrm{~min}$ and the trapped peptide was then separated by elution with a water/acetonitrile $0.1 \%$ formic acid gradient through a BEH 130 C18 column $(100 \mu \mathrm{m} \times 100 \mathrm{~mm}$, Waters $)$, as previously described [3]. Data was acquired in data-dependent mode and the peptide dissociated by collisions with argon. The assays conditions included a flow rate of $600 \mathrm{~nL} / \mathrm{min}$, nanoflow capillary voltage of $3.5 \mathrm{kV}$, block temperature of $100^{\circ} \mathrm{C}$, and cone voltage of $100 \mathrm{~V}$. The MS spectrum was analyzed manually from the ESI-MS/MS product ion mass spectra as previously described [19].

\subsection{Peptide synthesis and identification of peptide in Peptide Pool}

The peptides KEILG and KELLG were synthesized [1] with a purity grade greater than $95 \%$. With the aim of determining which peptide sequence was present in the venom, it was performed a RP-HPLC analysis as described above of a peptide mixture containing $20 \mu \mathrm{L}$ of venom Peptide Pool, with $40 \mu \mathrm{M}$ of KEILG and $40 \mu \mathrm{M}$ of KELLG. This mixture was compared to the original Peptide Pool profile.

\subsection{Determination of the inhibition constant $\left(K_{i}\right)$}

The $K_{i}$ was determined using seven concentrations of QFS and two concentrations of KELLG and KEILG peptides, maintaining the same EP24.15 concentration. Controls without the peptides were also performed. The assay was carried out as described before. In order to analyze the mechanism of inhibition for both peptides, an Eadie-Hofstee plot was constructed and, based on the type of mechanism, the $K_{i}$ was calculated as described [21].

\section{Results}

After verifying the Peptide Pool inhibitory efficiency upon the QFS hydrolysis by EP24.15, the first step of purification using a C-18 reverse-phase was performed. Fourteen peptide peaks were obtained and submitted to peptidase screening, reaching a single one responsible for the inhibitory effect. This peak was submitted to the same purification method described before, but using a slower gradient, resulting in three new peaks, yet only one inhibited EP24.15 activity. For this reason, it was submitted to LC-MS/MS analyses, revealing the pentapeptide KEXXG (Fig. 1, panel A), where $X$ could represent isoleucine/leucine. Two peptides were synthesized, KELLG and KEILG, to observe its performance at RP-HPLC and inhibition analyses. The retention time (\%ACN) range on RP-HPLC between both peptides was around $1 \mathrm{~min}$, indicating a differentiation based on hydrophobicity. After this, a Peptide Pool mixture containing both peptides as well as a control profile of Peptide Pool without treatment were prepared, as shown in Fig. 1 (panel B). We observed that KEILG was already present in the control sample, while KELLG had no match, changing the profile when compared with the Peptide Pool. Considering this, we concluded that the KEILG fragment was the sequence present in the venom. After RPHPLC differentiation, the mechanisms and inhibition constants for both peptides upon EP24.15 activity were determined. It is worth noting that both peptides were not hydrolyzed by EP24.15 even after a long period of incubation using bradykinin as a positive control (data not shown). As shown in Fig. 2, different mechanisms of inhibition were found: while KELLG is a competitive inhibitor $\left(K_{i}=84 \mu \mathrm{M}\right)$, KEILG acts through an uncompetitive mech$\operatorname{anism}\left(K_{i}=16 \mu \mathrm{M}\right)$. In addition, assays with an EP24.15 homologue, neurolysin (EC 3.4.24.16; EP24.16) were made, however, unexpectedly, this peptidase was not blocked by any of the two peptides (data not shown).

\section{Discussion}

Recently, the study of small peptides has gained importance through the scientific community and, in this context, our aim was to study bioactive peptides from TsV. Animal venoms peptides have a natural stability and a high selectivity, being preserved during evolution, which may suggest a functional importance in the venom. In addition, the pharmacologic potential of these molecules has attracted the attention of pharmaceutical industries to the development of new drugs, as previously occurred with other venom molecules [10].

Due to the obtainment methodology used here, we successfully purified a peptide of only five residues $\left(\mathrm{K}^{1} \mathrm{E}^{2} \mathrm{X}^{3} \mathrm{X}^{4} \mathrm{G}^{5}\right.$, whereas $\mathrm{X}=\mathrm{Leu} / \mathrm{Ile}$ ). However, we faced a challenge due to the mass spectrometry technique employed here that could not determine the correct amino acid at the indicated positions, since Leu and Ile are indistinguishable because both are characterized by a 113 Da mass in the MS/MS spectrum.

During our data analysis we noticed a similarity between $\mathrm{K}^{1} \mathrm{E}^{2} \mathrm{X}^{3} \mathrm{X}^{4} \mathrm{G}^{5}$ and the propeptide regions of potassium channel toxins ( $\beta$-KTx) described for Tityus species. All known sequences had a Leucine in the $\mathrm{P} 4$ position, showing to be a conserved residue among species. On the other hand, the residue in the $\mathrm{P} 3$ position was reported as Valine, in the GKGKEVLGKIK fragment [9] and also as Isoleucine, in the EKGKEILGKI fragment for T. cambridgei [2]. It is important to note that these results were obtained based on Edman 


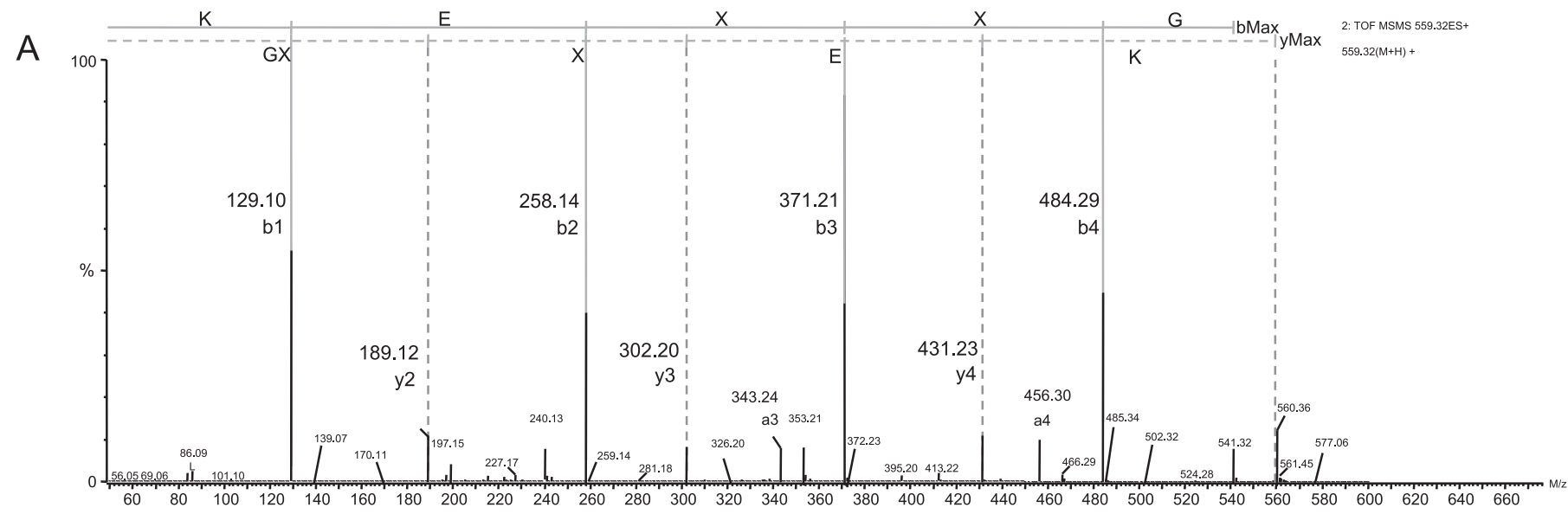

B

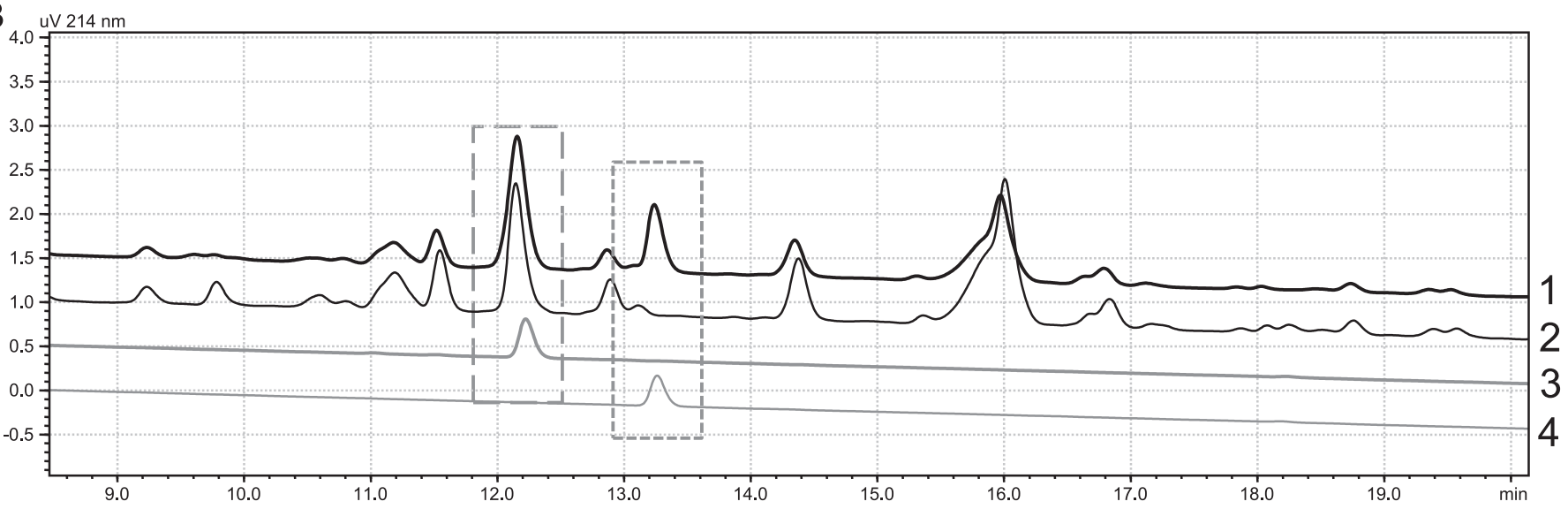

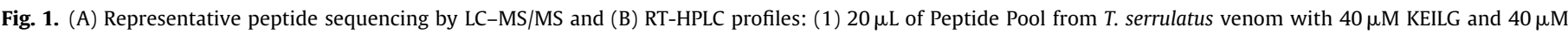

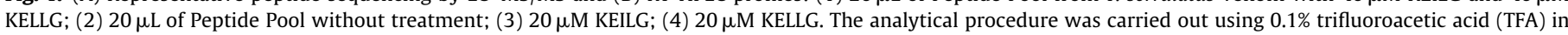

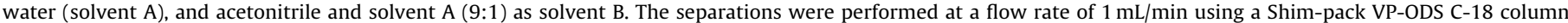
$(4.6 \times 150 \mathrm{~mm})$ with a gradient of $1.25 \% \mathrm{~B} / \mathrm{min}$, and elution was followed by ultraviolet absorption $(214 \mathrm{~nm})$.

sequencing or by mRNA level. Regarding TsV, there is a description, by homology level, of the peptide GKGKEILGKIKE ( $\beta$-KTx propeptide fragment) using mass spectrometric analysis [16].

After the peptides identification assay in HPLC, we concluded that KEILG was present in the venom, which corresponds to the reported sequence of the $\beta$-KTx propeptide from TsV [16]. In general, the proposed propeptide function is to prevent activity of the mature molecule, however other physiological functions are not well characterized. Therewith, we show here that a fraction of the $\beta$-KTx propeptide is present on the venom and have an important activity in vitro. Considering it, we suggest that $\beta-\mathrm{KTx}$ propeptide is a precursor of bioactive molecules not only for $\beta$-KTx
A

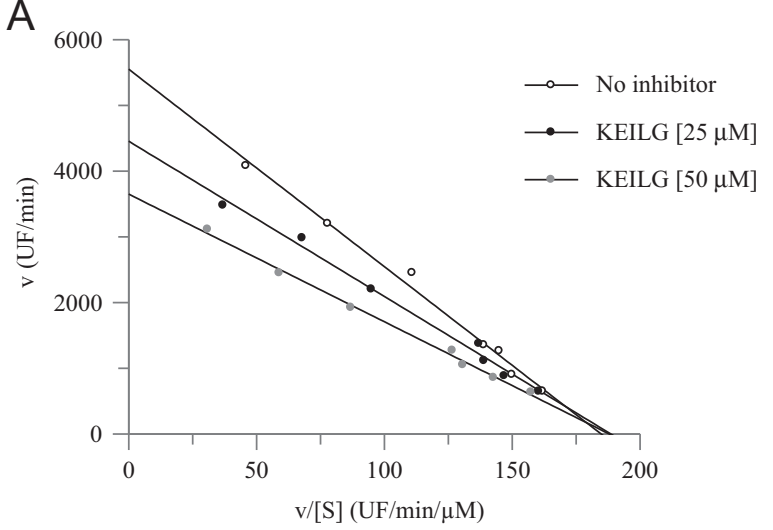

Uncompetitive inhibitor $(\mathrm{Ki}=16 \mu \mathrm{M})$
B

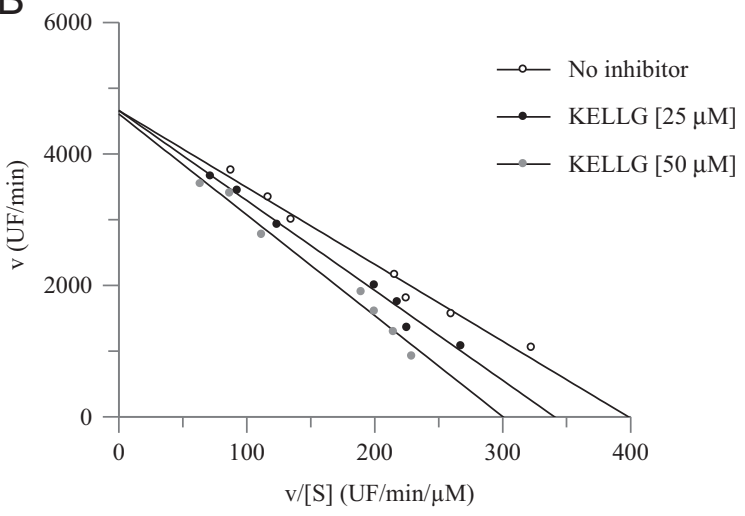

Competitive inhibitor $(\mathrm{Ki}=84 \mu \mathrm{M})$

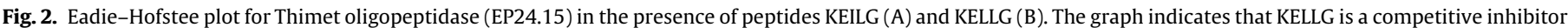

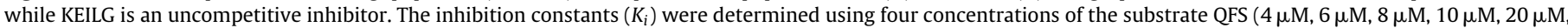

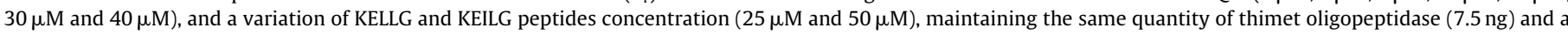
control experiment (without the peptides). The experiments were made in triplicate. 
but also for the small peptide KEILG. It is important to emphasize that KEILG is certainly a new naturally occurring peptide of TsV and not a degradation product of $\beta$-KTx propeptide, since the TsV has a low peptidase activity [6] and, moreover, we took preventive measures to avoid degradation of the peptides in the venom, as previously described here in Section 2.1.

The determinations of the inhibition mechanisms of synthetic peptides upon EP24.15 show different interactions, as well distinct $K_{i}$ values. The interference of KEILG in enzyme-substrate complex could be a result of the isoleucine amino acid affinity to the enzyme after conformational changes in the oligopeptidase during its binding with the substrate, which is consistent with the observations that simple amino acid substitutions can change the scissile bond on substrates [5] or get resistance to its hydrolyses [11], specifically for EP24.15. The same hypothesis could explain the KELLG inhibition mechanism, which only binds in the free peptidase, leading us to believe that the amino acid in position P3 is crucial to determine the interaction of this sequence with EP24.15. In addition, none of the two peptides could inhibit EP24.16 (data not show). We found this result to be very exciting, since they are members of clan MA, sharing substrates and inhibitors and, until now, no natural peptide described had differentiated EP24.15 and EP.24.16 [7,11,19].

\section{Conclusion}

In summary, the discovery of this peptide suggests a different processing mechanism for the $\beta$-KTx, since KEILG is a portion of its propeptide and shows in vitro activity, emphasizing the importance of the study of arthropods venom small peptides. In addition, we described a new naturally occurring peptide from TsV, KEILG, capable of reducing EP24.15 activity in vitro, which may be an important tool in further biochemical studies since it is capable of differentiate the oligopeptidases EP24.15 and EP24.16. The possible KEILG activity in vivo is under investigation in our laboratories.

\section{Conflict of interest statement}

The authors declare that there are no conflicts of interest.

\section{Acknowledgements}

We thank Dr. Emer S. Ferro for critical reading this manuscript. This study was supported by FAPESP, INCTTOX and CNPQ.

\section{References}

[1] Atherton E, Sheppard RC. Solid phase peptide synthesis: a practical approach. Oxford: Information Press Ltd.; 1989.

[2] Batista CV, del Pozo L, Zamudio FZ, Contreras S, Becerril B, Wanke E, et al. Proteomics of the venom from the Amazonian scorpion Tityus cambridgei and the role of prolines on mass spectrometry analysis of toxins. J Chromatogr B: Analyt Technol Biomed Life Sci 2004;803(1):55-66.

[3] Berti DA, Morano C, Russo LC, Castro LM, Cunha FM, Zhang X, et al. Analysis of intracellular substrates and products of thimet oligopeptidase in human embryonic kidney 293 cells. J Biol Chem 2009;284(21): 14105-16.

[4] Bortoluzzi LR, Querol MVM, Querol E. Notes on the occurrence of Tityus serrulatus Lutz \& Mello, 1922 (Scorpiones, Buthidae) in the Western areas of Rio Grande do Sul, Brazil. Biota Neotrop 2007;7:357-9.

[5] Camargo AC, Gomes MD, Reichl AP, Ferro ES, Jacchieri S, Hirata IY, et al. Structural features that make oligopeptides susceptible substrates for hydrolysis by recombinant thimet oligopeptidase. Biochem J 1997;324(Pt 2): 517-22.

[6] Cologna CT, Marcussi S, Giglio JR, Soares AM, Arantes EC. Tityus serrulatus scorpion venom and toxins: an overview. Protein Pept Lett 2009;16: 920-32.

[7] Dauch P, Vincent J-P, Checler F. Specific inhibition of endopeptidase 24.16 by dipeptides. Eur J Biochem 1991;202:269-76.

[8] DeBin JA, Maggio JE, Strichartz GR. Purification and characterization of chlorotoxin a chloride channel ligand from the venom of the scorpion. Am J Physiol 1993;264(2 Pt 1):C361-9.

[9] Diego-García E, Schwartz EF, D’suze G, González SA, Batista CV, García BI, et al. Wide phylogenetic distribution of Scorpine and long-chain beta-KTx-like peptides in scorpion venoms: identification of orphan components. Peptides 2007;28:31-7.

[10] Lewis RJ, Garcia ML. Therapeutic potential of venom peptides. Nat Rev Drug Discov 2003;10:790-802.

[11] Oliveira V, Campos M, Melo RL, Ferro ES, Camargo AC, Juliano MA, et al. Substrate specificity characterization of recombinant metallo oligo-peptidases. Biochemistry 2001;40(14):4417-25.

[12] Orlowski M, Michaud C, Chu TG. A soluble metalloendopeptidase from rat brain: purification of the enzyme and determination of specificity with synthetic and natural peptides. Eur J Biochem 1983;135(1):81-8.

[13] Pierotti A, Dong KW, Glucksman MJ, Orlowski M, Roberts JL. Molecular cloning and primary structure of rat testes metalloendopeptidase EC 3.4.24.15. Biochemistry 1990;29(45):10323-9.

[14] Pimenta AM, De Lima ME. Small peptides, big world: biotechnological potential in neglected bioactive peptides from arthropod venoms. J Pept Sci 2005;11:670-6.

[15] Quinton L, Gilles N, Smargiasso N, Kiehne A, De Pauw E. An unusual family of glycosylated peptides isolated from Dendroaspis angusticeps venom and characterized by combination of collision induced and electron transfer dissociation. J Am Soc Mass Spectrom 2011;22(11):1891-7.

[16] Rates B, Ferraz KK, Borges MH, Richardson M, De Lima ME, Pimenta AM. Tityus serrulatus venom peptidomics: assessing venom peptide diversity. Toxicon 2008;52(5):611-8.

[17] Ray K, Hines CS, Coll-Rodriguez J, Rodgers DW. Crystal structure of human thimet oligopeptidase provides insight into substrate recognition: regulation, and localization. J Biol Chem 2004;279(19):20480-9.

[18] Rioli V, Kato A, Portaro FC, Cury GK, te Kaat K, Vincent B, et al. Neuropeptide specificity and inhibition of recombinant isoforms of the endopeptidase 3.4.24.16 family: comparison with the related recombinant endopeptidase 3.4.24.15. Biochem Biophys Res Commun 1998;250(1):5-11.

[19] Rioli V, Gozzo FC, Heimann AS, Linardi A, Krieger JE, Shida CS, et al. Novel natural peptide substrates for endopeptidase 24.15 , neurolysin, and angiotensinconverting enzyme. J Biol Chem 2003;7:8547-55.

[20] Rioli V, Prezoto BC, Konno K, Melo RL, Klitzke CF, Ferro ES, et al. A novel bradykinin potentiating peptide isolated from Bothrops jararacussu venom using catalytically inactive oligopeptidase EP24.15. FEBS 2008;275(10):2442-54.

[21] Segel IH. Enzyme kinetics. New York: Wiley; 1975. p. 100-59.

[22] Wu XS, Jian XC, Yin B, He ZJ. Development of the research on the application of chlorotoxin in imaging diagnostics and targeted therapies for tumors. Chin J Cancer 2010;29(6):626-30. 